\title{
VENTSAR XL - A SPREADSHEET FOR ANALYZING BUILDING EFFECTS AND PLUME RISE
}

\author{
$1 / 2$
}

A. A. Simpkins

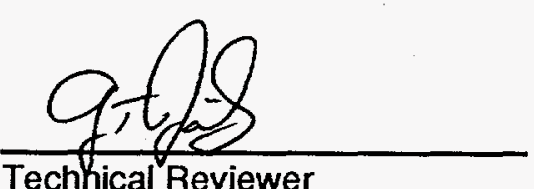

March 1997

Westinghouse Savannah River Company Savannah River Site

Alken, SC 29808

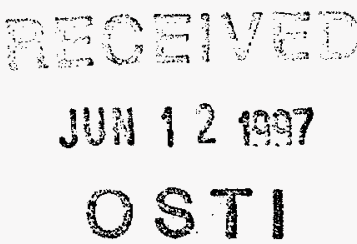

MASTER

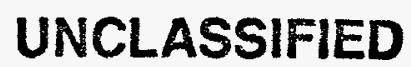

DOES NOT CONTAN

UNCLASSIFIED CONTROUED

NUCLEAR INFORMATION

$A D C$ \&

Reviowing

Official. IDBmares blednow

Date: $L_{2} \quad 5 / 1 / 97$

DISTRIBUTION OF THIS DOCUMENT IS UNLIMTED

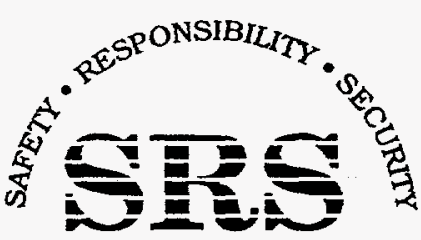

SAVANNAH RIVER SITE

PREPARED FOR THE U.S. DEPARTMENT OF ENERGY UNDER CONTRACT NO. DE-ACO9-8\&SR18035 


\section{DISCLAIMER}

This report was prepared as an account of work sponsored by an agency of the United States Government. Neither the United States Government nor any agency thereof, nor any of their employees, makes any warranty, express or implied, or assumes any legal liability or responsibility for the accuracy, completeness, or usefulness of any information, apparatus, product, or process disclosed, or represents that its use would not infringe privately owned rights. Reference herein to any specific commercial product, process, or service by trade name, trademark, manufacturer, or otherwise does not necessarily constitute or imply its endorsement, recommendation, or favoring by the United States Government or any agency thereof. The views and opinions of authors expressed herein do not necessarily state or reflect those of the United States Government or any agency thereof.

This report has been reproduced directly from the best available copy.

Available to DOE and DOE contractors from the Office of Scientific and Technical Information, P.O. Box 62, Oak Ridge, TN 37831; prices available from (615) 576-8401.

Available to the public from the National Technical Information Service, U.S. Department of Commerce; 5285 Port Royal Road, Springfield, VA 22161. 


\section{DISCLAMMER}

Portions of this document may be illegible in electronic image products. Images are produced from the best available original document. 
Retention: Lifetime

\title{
VENTSAR XL - A SPREADSHEET FOR ANALYZING BUILDING EFFECTS AND PLUME RISE
}

\author{
A. A. Simpkins
}

Issued: March 1997

SRTC

SAVANNAH RIVER TECHNOLOGY CENTER

AIKEN, SC 29808

Westinghouse Savannah River Company

Savannah River Site

Aiken, SC 29808

PREPARED FOR THE U.S. DEPARTMENT OF ENERGY UNDER CONTRACT NO. DE-AC09-89SR18035 


\section{ABSTRACT}

VENTSAR XL is a Microsoft Excel spreadsheet that analyzes flow patterns of pollutants on or near buildings. Plume rise may be considered. This report provides a complete description and verification of all models within VENTSAR XL. User instructions also are included. 


\section{TABLE OF CONTENTS}

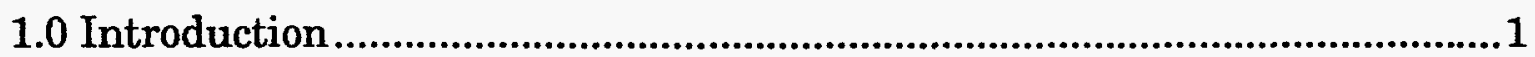

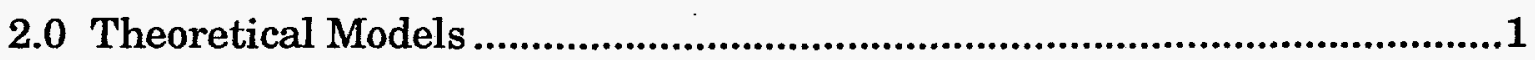

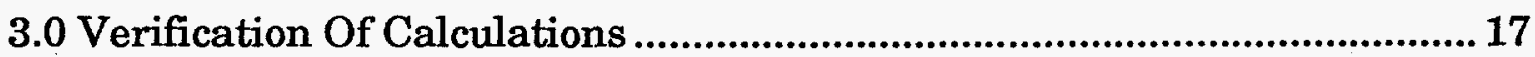

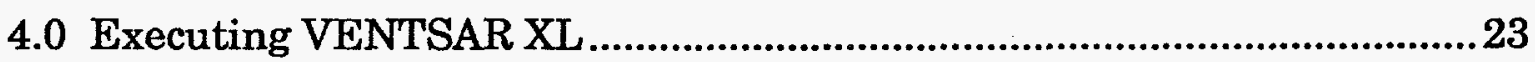

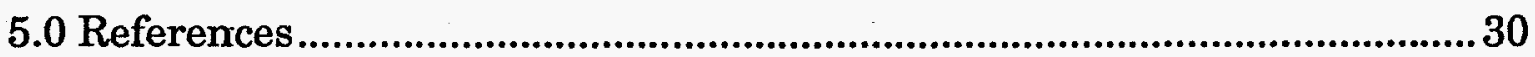

Appendix A. Meteorological File Description ...................................................32

Appendix B. Original Test Case Demonstration ...........................................35

Appendix C Additional Test Case Demonstration ...........................................51

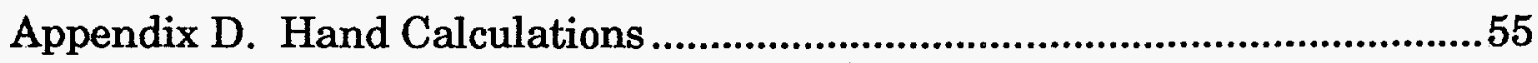




\section{LIST OF TABLES}

Table 1. Wind Speed Category Ranges for SRS Files .....................................3

Table 2. Classification of Atmospheric Stability ...............................................3

Table 3. Comparison of VENTSAR and VENTSAR XI for Test Case 2 ........ 18

Table 4. Input parameters for Plume Rise Verification................................. 19

Table 5. Hand Calculations for Plume Rise Verification ...............................20

Table 6. Input parameters for Building Wake Effects Verification ................21

Table 7. Hand Calculations for Building Wake Effects Verification..............21

Table 8. Input parameters for Building Wake Effects and PR

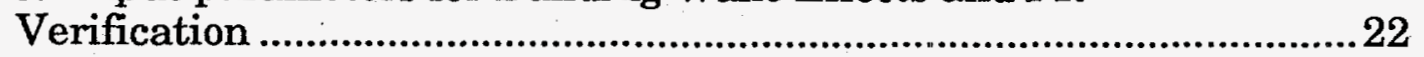

Table 9. Hand Calculations of Relative Air Concentrations ........................23

Table 10. Hand Calculations of Dose Predictions .............................................23

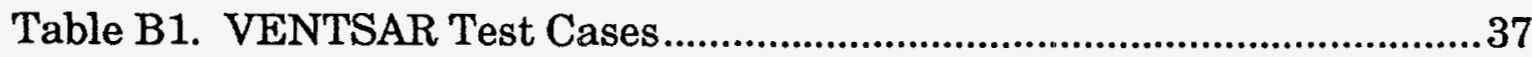

Table B2. Results for Test Case 1 (Release Height =50 m) .........................38

Table B3. Results for Test Case 1 (Release Height =55 m) ...........................43

Table C1. Test Cases Parameters ....................................................................52

Table C2. Comparison of VENTSAR XL and VENTSAR ..............................53 


\section{LIST OF FIGURES}

Figure 1. Recirculation Zones for Building Wake Effects Calculations...... 11

Figure 2. Dimensions of Buildings used with VENTSAR XL ..................... 12

Figure 3. Concentration locations for Building Wake Effects

Verification

Figure 4. Input Template for VENTSAR XI ............................................... 24

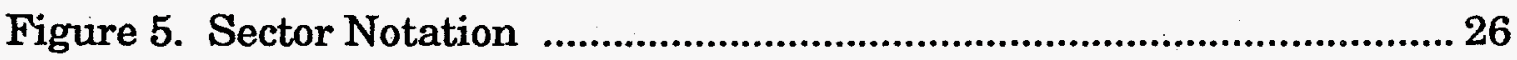

Figure 6. Release Location Explanation for Input........................................ 27

Figure 7. Sample Output for VENTSAR XL ............................................. 29

Figure A1. Sample Meteorological File.................................................... 34 


\title{
VERIFICATION OF VENTSAR XI - A SPREADSHEET FOR ANALYZING BUILDING EFFECTS AND PLUME RISE
}

\author{
A. A. Simpkins \\ Westinghouse Savannah River Company \\ Savannah River Technology Center \\ Aiken, SC 29808
}

\subsection{INTRODUCTION}

VENTSAR XL is an upgraded and improved spreadsheet version of the VENTSAR code which originated as VENTX (Smith and Weber 1983) on the IBM Mainframe at the Savannah River Site (SRS). VENTSAR XL estimates contaminant concentrations on or near a building from a release at a nearby location. The code calculates the concentrations for a given meteorological exceedance probability or for a given stability and wind speed combination. A single building can be modeled and a penthouse can be added to the top of the building. Plume rise also may be considered. Contaminant release types can be chemical or radioactive. Downwind concentrations are determined at user-specified incremental distances. If the release is radioactive, doses may be calculated.

\subsection{THEORETICAL MODELS}

This section discusses the theoretical models and data files that are employed within VENTSAR XL.

\subsection{Gaussian Plume Model}

The pollutant dispersion calculations in the VENTSAR XL code are based on a reflecting Gaussian plume model (Hanna 1982). Along the plume centerline, the dispersion factor or relative air concentration, defined as the ratio of the pollutant concentration $\chi\left(\mathrm{kg} / \mathrm{m}^{3}\right.$ or $\left.\mathrm{Ci} / \mathrm{m}^{3}\right)$ to the source strength $Q(\mathrm{~kg} / \mathrm{sec}$ or $\mathrm{Ci} / \mathrm{sec})$, is given by the equation:

$$
\frac{\chi}{Q}=\frac{1}{2 \pi \sigma_{y} \sigma_{z} U_{S}}\left[e^{-\left(\frac{\left(z-h_{e}\right)^{2}}{2 \sigma_{z}^{2}}\right)}+e^{-\left(\frac{\left(z+h_{e}\right)^{2}}{2 \sigma_{z}^{2}}\right)}\right]
$$

where

$\chi / Q \quad$ the dispersion factor $\left(\mathrm{sec} / \mathrm{m}^{3}\right)$ 
$z \quad$ height above the ground surface (m)

he effective release height (m)

$U_{S} \quad$ wind speed at the release height, $(\mathrm{m} / \mathrm{sec})$

oy the standard deviation of the concentration distribution in the horizontal cross-plume direction (m)

$\sigma_{z}$ the standard deviation of the concentration distribution in the vertical direction $(m)$

Annual average values of $\chi / Q$ are calculated as:

$$
\operatorname{annual}(\overline{\chi / Q})=\sum_{i, j}^{6,7} P_{i j}\left(\frac{\chi}{Q}\right)_{i j}
$$

where

$i \quad$ wind speed category

$j \quad$ stability class

$(\chi / Q)_{i} \quad$ relative air concentration for meteorological condition $(i, j)$

$P_{i} \quad$ the probability of a particular meteorological condition (i,j) occurring within a five-year time period

\subsubsection{Meteorological Data Files}

VENTSAR XL accesses a meteorological joint frequency distribution (JFD) containing 6 wind speed classes (see Table 1) and 7 stability categories. VENTSAR XL contains meteorological data files already available for SRS, but the user may add data files of their choice from any location. To create a new meteorological file the user should open an existing file and make the necessary changes and "Save As" the new file. This will ensure that the proper format is used. Sample file format is shown in Appendix A with a complete explanation of input. 
Table 1. Wind Speed Category Ranges for SRS Files

\begin{tabular}{|c|c|}
\hline $\begin{array}{c}\text { Speed } \\
\text { Category }\end{array}$ & $\begin{array}{c}\text { Range } \\
(\mathrm{m} / \mathrm{sec})\end{array}$ \\
\hline 1 & $0<\mathrm{U} \leq 2$ \\
2 & $2<\mathrm{U} \leq 4$ \\
3 & $4<\mathrm{U} \leq 6$ \\
4 & $6<\mathrm{U} \leq 8$ \\
5 & $8<\mathrm{U} \leq 12$ \\
6 & $\mathrm{U} \geq 12$ \\
\hline
\end{tabular}

Atmospheric stability is classified by standard deviations of the lateral or azimuthal wind direction. Area meteorological towers contain

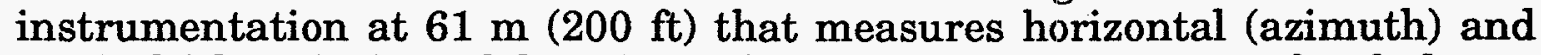
vertical (elevation) wind directions. Also, direct measurements of turbulence, expressed as standard deviations of fluctuations about mean azimuth (noted either as $\sigma_{a}$ or $\left.\sigma_{\theta}\right)$ and elevation $\left(\sigma_{e}\right)$ angles, are made at $61 \mathrm{~m}$.

For calculational purposes within the spreadsheet, an assumed average value of $\sigma_{\theta}$ is chosen for the atmospheric stability class of interest. Ranges for $\sigma_{\theta}$ and the values that are used within VENTSAR XL are shown in Table 2.

Table 2. Classification of Atmospheric Stability

\begin{tabular}{|c|c|c|}
\hline $\begin{array}{c}\text { Pasquill } \\
\text { Category }\end{array}$ & $\begin{array}{c}\text { Range for } \sigma_{\theta} \\
\text { (degrees) }\end{array}$ & $\begin{array}{c}\sigma_{\theta} \text { Used in } \\
\text { VENTSAR XL } \\
\text { (degrees) }\end{array}$ \\
\hline A & $23 \leq \sigma_{\theta}$ & 27.5 \\
B & $18 \leq \sigma_{\theta}<23$ & 22.5 \\
C & $13 \leq \sigma_{\theta}<18$ & 17.5 \\
D & $8 \leq \sigma_{\theta}<13$ & 12.5 \\
E & $4 \leq \sigma_{\theta}<8$ & 7.5 \\
F & $2 \leq \sigma_{\theta}<4$ & 3.75 \\
G & $\sigma_{\theta}<2$ & 2.00 \\
\hline
\end{tabular}

\subsubsection{Pasquill-Briggs Diffusion Coefficients}

The lateral and vertical diffusion coefficients within VENTSAR XL are those derived by Pasquill (1976) and Briggs (1973), respectively. The equation representing Pasquill's lateral diffusion coefficients is

$$
\sigma_{y}=\sigma_{\theta} X f(X)
$$


where

$\sigma_{\theta} \quad$ standard deviation of lateral wind direction (radians) [See Table 2]

$X \quad$ downwind distance $(\mathrm{km})$

$f(X)$ function of distance, $X(\mathrm{~km})$, as discussed below

Pasquill developed formulations for $f(X)$ with a table of values for distances less than $10 \mathrm{~km}$ and the following equation for distances greater than $10 \mathrm{~km}$ :

$$
f(X)=0.33\left[\frac{10}{X}\right]^{0.5}
$$

For distances less than $10 \mathrm{~km}$, the following equation was derived from the table of values with $X$ in kilometers:

$$
f(X)=\frac{1}{1+0.031(1000 X)^{0.46}}
$$

Pasquill (1976) gives a detailed description on how the coefficients were developed using data from experiments at various sites.

The vertical diffusion coefficients defined by Briggs (1973) and then refined by Briggs and published in Hanna (1982) for open-country conditions are represented in Table 3 as a function of Pasquill's atmospheric stability classes.

Table 3. Brigg's Vertical Diffusion Coefficient Formulas

\begin{tabular}{|c|l|}
\hline $\begin{array}{c}\text { Pasquill Stability } \\
\text { Category }\end{array}$ & \multicolumn{1}{|c|}{$\sigma_{\mathrm{z}}(\mathrm{X}$ in meters $)$} \\
\hline $\mathrm{A}$ & $0.20 X$ \\
$\mathrm{~B}$ & $0.12 X$ \\
$\mathrm{C}$ & $0.08 X(1+0.0002 X)^{-0.5}$ \\
$\mathrm{D}$ & $0.06 X(1+0.0015 \mathrm{X})^{-0.5}$ \\
$\mathrm{E}$ & $0.03 X(1+0.0003 X)^{-1}$ \\
$\mathrm{~F}$ & $0.02 X(1+0.0003 X)^{-1}$ \\
$\mathrm{G}$ & $0.01 X(1+0.0003 X)^{-1}$ \\
\hline
\end{tabular}




\subsection{Plume Rise}

Plume rise models are based on fundamental laws of fluid mechanics, conservation of mass, potential density, and momentum. The quantities across the plume are referred to as "top-hat" meaning that discontinuities in temperature, speed and etc. are assumed at the plume boundary. Therefore, for the models employed here, constant values are assumed inside the plume, and another set of constant values is assumed outside of the plume. VENTSAR XL considers plume rise due to both buoyancy and momentum effects.

Several different mechanisms can increase or decrease the height of the plume at downwind distances. Plume rise due to momentum and buoyancy effects can increase the height of the plume while downwash can decrease the height of the plume. The effective plume height at a given distance, $X$, downwind is

$$
h(X)=h_{s}-\Delta h_{D}+\Delta h_{B}(X)+\Delta h_{M}(X)
$$

where

$h_{s} \quad$ initial height of the source

$\Delta h_{D} \quad$ source height change due to downwash

$\Delta h_{B} \quad$ source height change due to buoyancy effects

$\Delta h_{M} \quad$ source height change due to momentum effects

\subsubsection{Downwash}

Downwash occurs when the plume is drawn downward due to low pressure in the wake of the stack. Downwash will not occur if the velocity of the effluent $\left(V_{e},\right)$ is a significantly greater than the wind speed $(U)$. Downwash is generally recognized to occur when $V_{e} / U$ is less than 1.5 (Briggs 1973). When the ratio is less than 1.5 the following equation is applied to determine the effects of downwash (Hanna 1982):

$$
\Delta h_{D}=2\left(\frac{V_{e}}{U}-1.5\right) D
$$

where

$D \quad$ the internal stack diameter (m)

$V_{e} \quad$ effluent velocity $(\mathrm{m} / \mathrm{s})$

$U \quad$ wind speed $(\mathrm{m} / \mathrm{s})$ 
Recent work by Snyder (1991) suggests that downwash seldom has consequences due to the fact that conditions are typically associated with small diameters, and the change in stack height due to downwash is only of a few diameters. Snyder states that "serious downwash will occur only for sources with: $\mathrm{V}_{\mathrm{e}} \mathrm{D}<0.5(60,000)\left(0.15 \mathrm{~cm}^{2} \mathrm{~s}^{-1}\right) \sim 0.5 \mathrm{~m}^{2} \mathrm{~s}^{-1}$."

\subsubsection{Buoyancy Effects}

For most plumes the primary contributor to rise is buoyancy, which results from density differences between the effluent and the atmosphere (Briggs 1984). The initial buoyancy flux for a plume is determined by (Hanna 1982):

$$
F_{o}=g(D R H O)(C M S)
$$

where

$\begin{array}{ll}F_{o} & \text { buoyancy flux }\left(\mathrm{m}^{4} / \mathrm{s}^{3}\right) \\ g & \text { acceleration due to gravity }\left(9.8 \mathrm{~m} / \mathrm{s}^{2}\right) \\ C M S & \text { volume flux at the stack exit }\left(\mathrm{m}^{3} / \mathrm{s}\right) \\ D R H O & \text { density ratio (unitless), defined below }\end{array}$

Plumes are considered dense when the density ratio, $D R H O$, is greater than zero (Meroney 1982a). DRHO is determined using the following equation:

$$
D R H O=\frac{M W_{a} T_{e}-M W_{e} T_{a}}{2 M W_{a} T_{e}}
$$

where

$M W_{e} \quad$ molecular weight of the effluent

$M W_{a} \quad$ molecular weight of the air (28.9)

$T_{e} \quad$ temperature of effluent (K)

$T_{a} \quad$ temperature of air (K)

The Froude number $(F r)$ is used to represent the ratio of inertial forces to buoyancy forces (Snyder 1972). If $D R H O \leq 0$, the plume is lighter than air and the Froude number is not determined. The plume falls to the ground close to the source when the Froude number is less than 7.7 (Meroney 1982a). The Froude number is calculated as follows: 


$$
F r=\frac{U}{\sqrt{g * D R H O * D}}
$$

where

Fr Froude number (unitless)

$U \quad$ wind speed $(\mathrm{m} / \mathrm{s})$

D plume exit diameter (m)

For the vertical motion of the plume, the environmental stability parameter, $S$, plays an important role for unstable conditions. The stability parameter is set to unity for all classes except $E, F$ and $G$ where

$$
S=\frac{g * \frac{\partial T_{a}}{\partial z}}{T_{a}}
$$

where

$S \quad$ stability parameter $\left(\mathrm{s}^{-2}\right)$

$\frac{\partial T_{a}}{\partial z}=0.02$ for $\mathrm{E}, 0.03$ for $\mathrm{F}$, and $0.04{ }^{\circ} \mathrm{C} / 100 \mathrm{~m}$ for G stability (Hanna 1982).

Now that many of the initializing parameters have been determined, the increase in plume height due to buoyancy can be calculated. For unstable to neutral conditions buoyancy is limited to a distance XSTR (in meters) from the source using the following formulations (Briggs 1969):

For $F_{o}>55 \mathrm{~m}^{4} / \mathrm{s}^{3}$

$$
X S T R=120.7 F_{o}^{0.4}
$$

For $F_{o} \leq 55 \mathrm{~m}^{4} / \mathrm{s}^{3}$

$$
X S T R=49.0 F_{o}^{0.625}
$$

Using the above determined distances, the increase in plume height due to buoyancy effects for unstable to neutral conditions where $X<X S T R$ is determined using the following equation (Briggs 1969): 


$$
\Delta h_{B}=1.6 \frac{F_{o}^{1 / 3} X^{2 / 3}}{U}
$$

For distances greater than XSTR for unstable to neutral conditions, the same equation is used, except $X$ is set to a constant value of XSTR.

For stability classes E, F and G with calm winds (given below) the increase in plume height is determined by the following (Briggs 1969):

$$
\Delta h_{B}=5.0\left[\frac{F_{o}}{S^{3 / 2}}\right]^{1 / 4}
$$

For stability classes $\mathrm{E}, \mathrm{F}$ and $\mathrm{G}$ with the wind speed greater than the calm wind speed, and for distances greater than or equal to XTST=2.07U/SP buoyancy is less dominating and the increase in plume height is given by the following (Hanna 1982):

$$
\Delta h_{B}=2.6\left[\frac{F_{o}^{\prime}}{(U) S}\right]^{1 / 3}
$$

For distances less than XSTR, Equation 14 is applied.

By setting equations 15 and 16 equal and solving for $U$, calm winds are given by the following relationship:

$$
U<0.141^{*}\left(F_{o} * S^{1 / 2}\right) 0.25 \mathrm{~m} / \mathrm{s}
$$

\subsubsection{Momentum Effects}

Plume rise may also occur because the initial vertical velocity of the effluent is great enough to elevate the plume. Plume rise due to momentum effects near the source for unstable to neutral weather conditions (Stability Classes $\mathrm{A}-\mathrm{D}$ ) is determined by the following equation (Briggs 1976):

$$
\Delta h_{M}=\left[\frac{3 \pi}{4 \beta^{2}}\right]^{1 / 3}\left[\frac{D W_{e} M_{o}}{U}\right]^{2 / 3} X^{1 / 3}
$$

where

$\beta \quad=0.4+1.2 U / V_{e}$, (unitless),

$U \quad$ wind speed $(\mathrm{m} / \mathrm{s})$

$V_{e} \quad$ effluent velocity $(\mathrm{m} / \mathrm{s})$ 
$D \quad$ diameter of the stack (m)

$M_{O}$ measure of relative density of effluent plume to that of air:

$$
M_{0}=\left[\frac{M W_{e} T_{a}}{M W_{a} T_{e}}\right]^{1 / 2}
$$

$X \quad$ downwind distance (m)

For ease in calculation within the spreadsheet the equation is rewritten as

$$
\Delta h_{M}=\left[B 1 * X * D H M O M^{2}\right]^{1 / 3}
$$

where

$$
\begin{aligned}
& B 1=\frac{0.75 * \pi}{\left(0.4+1.2 U / V_{e}\right)^{2}} \\
& D H M O M=D * \frac{V_{e}}{U} M_{o}
\end{aligned}
$$

with all terms previously defined.

The above equation is applicable for all distances less than XTEST where

$$
X T E S T=\frac{27.0 D H M O M}{B 1}
$$

For distances where $\mathrm{X} \geq \mathrm{XTEST}$ the increase in plume height due to momentum effects is given by the following equation (Briggs 1969):

$$
\Delta h_{M}=3 D H M O M
$$

For stable weather conditions (Stability Classes E, F, and G) the change in plume height due to momentum effects is equal to the minimum of the following two equations (Briggs 1969):

$$
\begin{gathered}
\Delta h_{M}=4.0 \sqrt{\frac{D H M O M * U}{2 S^{1 / 2}}} \\
\Delta h_{M}=1.5\left(\frac{D H M O M^{2} U}{4 S^{1 / 2}}\right)^{1 / 3}
\end{gathered}
$$




\subsection{Building Wake Effects}

An exact mathematical solution to the plume interaction with air flow does not exist. However, a great deal of useful quantitative information has been obtained using wind-tunnel simulations of flow around model buildings, and a limited number of measurements around full-scale buildings of relatively simple geometry. Semi-empirical models consolidating these simulations and experiments are available for estimating pollutant concentrations around buildings. A summary of the methods available for determining flow patterns and pollutant concentrations near buildings with a simple block-like structure has been prepared by Hanna (1982).

Wind passing over and around buildings creates a complicated dispersion pattern. A recirculation cavity and zones of high turbulence are created on the building roof with a roof cavity region produced downwind of the structure. These regions may trap effluent material and produce high ground- or roof-level concentrations. Models that neglect turbulence effects near structures will usually underestimate pollutant concentrations on building roofs or near buildings. Since air-intake vents may be located on building roofs or near the ground downwind of a release source, an estimation of pollutant concentrations on or near a structure is important in determining expected pollutant levels. Therefore, a methodology was adapted to determine the effect of plume interaction with the air-flow pattern around buildings. This provides a useful tool for determining heights of new stacks so that acceptable pollutant levels near the source and downwind buildings can be assured.

Figure 1 (Wilson 1979) shows a cross-section of the flow over a building with the wind perpendicular to the face of the building. The recirculation cavity (Zone I) is created due to the separation of the flow from the upwind edge of the roof. The flow recirculates and the turbulence levels are very high. Only if the roof is long enough will the flow reattach to the roof. The boundary of the high turbulence region (Zone II) is not precisely defined. Turbulence generated in the shear layers at the edge of the recirculation cavity result in accelerated diffusion to the roof level of any gases. Zone II is defined such that it also includes Zone I. The roof wake region (Zone III) is depicted in Figure 1 in an exaggerated form. This region's boundary is essentially straight and parallel with the flow. Gases that are released in this region will have some downwash and more rapid spreading than the gases above Zone III. Zone III also includes Zones I and II.

Analytical models have been associated with the regions discussed previously. Building effects are included in the model using the techniques presented by Wilson (1979). The dimensions of recirculation zones, high turbulence zones, and wake cavities associated with the building and any penthouse structure are determined based on building dimensions. If the plume is not over the building or the downwind wake cavity, the height above the ground, $\mathrm{z}$, is set equal to zero to give ground-level concentrations. 
Figure 1. Recirculation Zones for Building Wake Effects Calculations

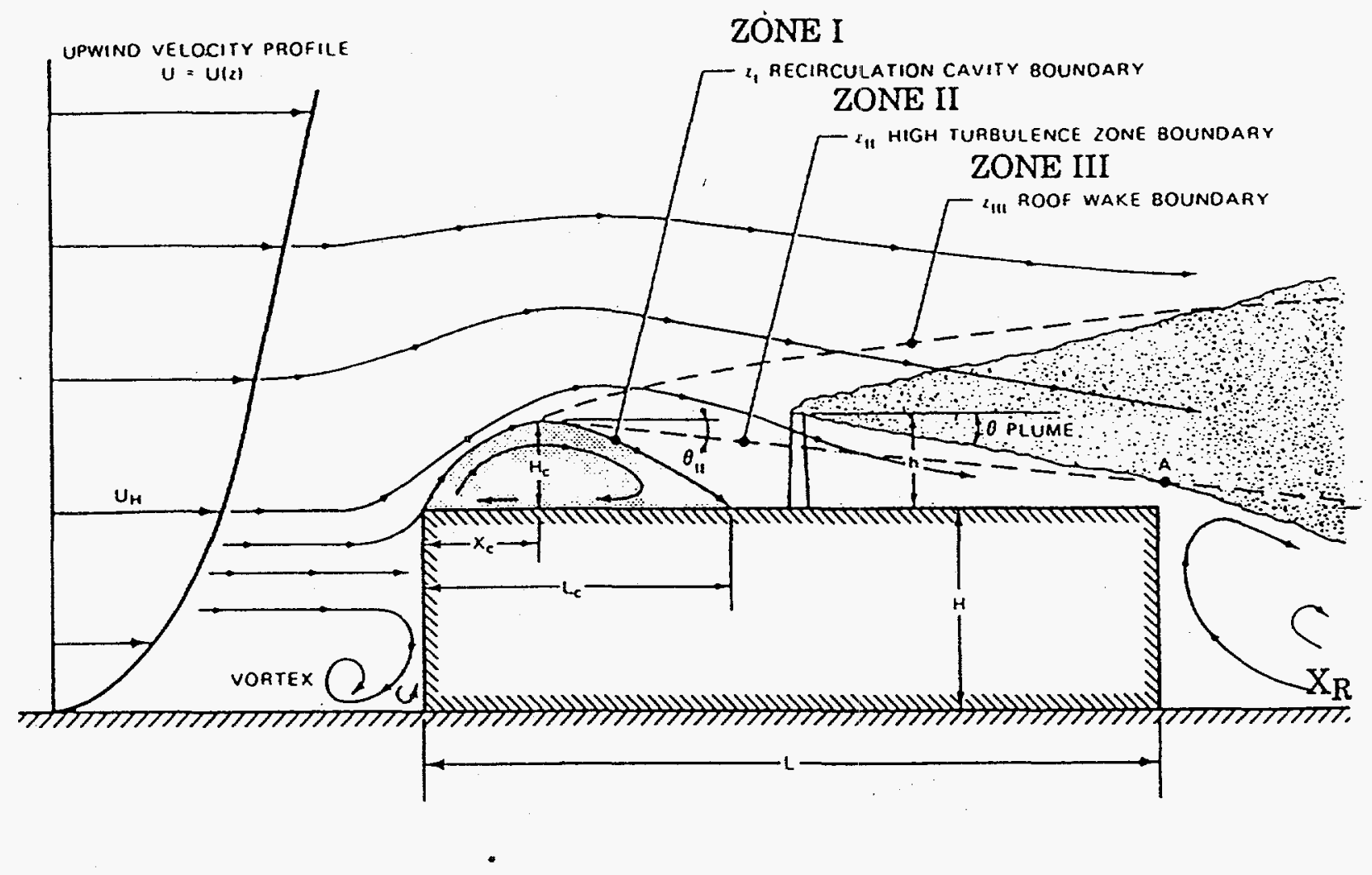


Various fluid modeling experiments have led to the development of models to predict the behavior of wind flow around buildings. The dimensional parameters describing the building of interest in VENTSAR XL are shown in Figure 2. These dimensions are consistent with the wind being perpendicular to the building face. When ratios of $L / H$ (where $L$ and $H$ correspond to the length and height of the building or penthouse) are greater than one, reattachment of streamlines to the roof and sides is expected. This however, may not be the case if $W / H$ is very large. The length the recirculation cavity zone (Zone I) extends from the upwind edge of the building is given by the following expression:

$$
L_{c} \approx 0.9 R
$$

where

$$
R \approx\left(B_{\min }\right)^{2 / 3}\left(B_{\max }\right)^{1 / 3}
$$

where $B_{\min }$ is the smaller of $H$ or $W$ and $B_{\max }$ is the larger. The length of the cavity zone should be calculated for both the building and penthouse separately and then summed. All building dimension units are in meters.

Figure 2. Dimensions of Building and Penthouse used with VENTSAR XL

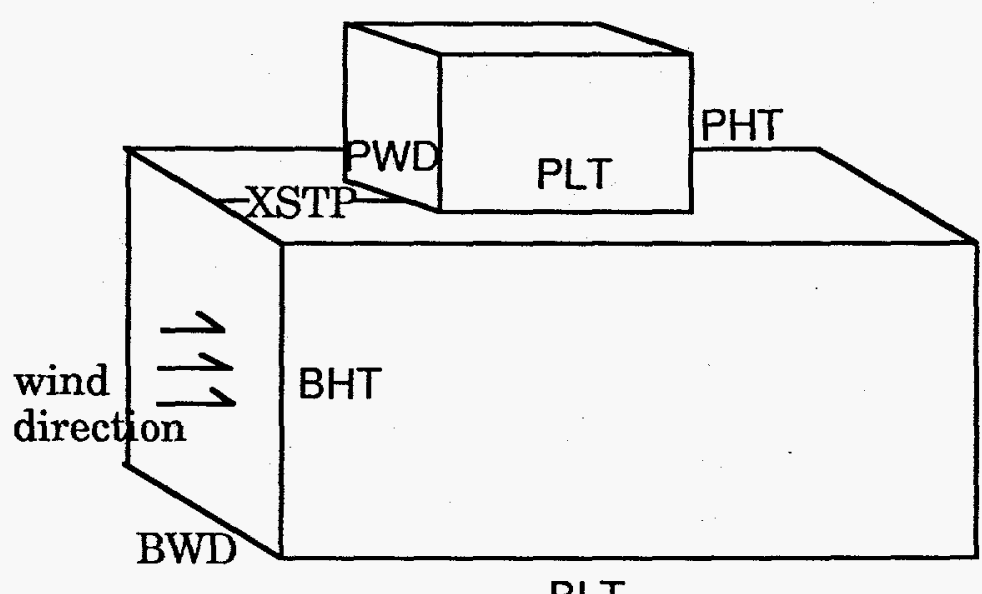

The maximum height of the recirculation zone (Zone $\mathrm{I}$ ) is

$$
H_{c} \approx 0.22 R
$$

and is assumed to occur at a distance of $R / 2$ from the edge of the building. The length of the cavity zone is defined for both the building and the penthouse. 
The distance beyond the building where plumes may be caught and mixed to the ground is called the wake cavity. The empirical formula for the length of the wake cavity is (Hanna 1982):

$$
X_{r}=\frac{A * W}{1+B(W / H)}
$$

where

W the building width

$H \quad$ the building height

$A$ and $B$ are discussed below

Separate values for $A$ and $B$ are used depending on whether the flow reattaches to the roof and sides of the building. Cases of reattachment occur when $L / H \geq 1$. For this case

$$
\begin{aligned}
& A=1.75 \\
& B=0.25
\end{aligned}
$$

For cases where the flow does not reattach to the building

$$
\begin{aligned}
& A=-2.0+0.37\left(\frac{L}{H}\right)^{1 / 3} \\
& B=-0.15+0.305\left(\frac{L}{H}\right)^{1 / 3}
\end{aligned}
$$

When the recirculation cavity does not reattach to the building roof, calculation of the effective release height is altered. Following Briggs, if the adjusted release height $h^{\prime}$ is less than the building height $H$, then the adjusted effective height is given by (Briggs 1973):

$$
h_{\text {eff }}=h^{\prime}-1.5 B_{\min }
$$

where

$h_{\text {eff }}$ the effective plume

$h^{\prime} \quad$ the release height adjusted by downwash and plume rise

$B_{\min }$ the smaller of the width or height of the building 
If the emission height is such that $H<h^{\prime}<H+1.5 B_{\text {min }}$, then the adjusted effective release height is:

$$
h_{\text {eff }}=2 h^{\prime}-\left(H+1.5 B_{\text {min }}\right)
$$

If $h^{\prime} \geq H+1.5 B_{\min }$, the plume is out of the wake of the building and no effects from the building are seen, therefore, $h_{\text {eff }}=h^{\prime}$.

When there is a change in elevation on the building roof, three separate flow regimes must be considered. Let $X_{s}$ be the distance from the leading edge of the building to the step change in roof elevation. $R_{u}$ and $R_{s}$ are the scaling lengths given by Equation 28 for the building and penthouse upwind faces, respectively. The following three flow regimes can occur:

(i) $X_{s}<0.5\left(R_{u}+R_{s}\right)$. The leading edge of the building is connected in a straight line to the top of the penthouse to form a recirculation cavity. Roof cavity heights and turbulence zone boundaries are calculated using $R=\left(R_{u}+R_{s}\right)$;

(ii) $0.5\left(R_{u}+R_{s}\right)<X_{s}<2\left(R_{u}+R_{s}\right)$. The recirculation cavity height $H_{c}$ and location $X_{c}$ on the upwind portion of the roof are calculated using $R=$ $R_{u}+R_{s}$. The top of this cavity region is joined in a straight line with the top of the penthouse to form a high turbulence zone. The cavity height on the penthouse roof and the downwind high turbulence zone boundary are then calculated using $R_{s}$ as a scale length; or

(iii) $X_{s}>2\left(R_{u}+R_{s}\right)$. The upwind roof and penthouse roof are treated as two separate buildings with scaling lengths $R_{u}$ and $R_{s}$, respectively.

Using the $R$ values determined above for a given point, the height of cavity Zone $I$ is determined (Wilson 1979).

For downwind distances less than $0.5 R$ :

$$
Z=0.28 R\left(\frac{X}{R}\right)^{1 / 3}
$$

where

$R \quad$ determined above based on building dimensions (m)

$X \quad$ downwind distance (m)

For downwind distance $X$ where $0.5 R<X \leq L$ : 


$$
Z=0.27 R-0.1 X
$$

For use within the code, the value of $Z$ calculated above is added to the height of the building to determine the relative air concentration. Beyond the building $Z=0$.

When building wake effects are considered, adjustments must be made to the relative air concentration equation. Some fraction $(f)$ of the effluent plume will be entrained into the wake cavity. For the model used in VENTSAR XL, this fraction is estimated as the ratio of $\chi / Q$ evaluated at the top of the cavity when it first forms to the value of $\chi / Q$ at the plume centerline. The material trapped within the wake cavity behaves as if it originates from an area source of building dimensions. Meroney (1982b) has shown that a simple expression useful for estimating pollutant concentrations within the cavity is:

$$
\left(\frac{\chi}{Q}\right)_{c a v}=\frac{f}{H W U_{s}}
$$

Equation 39 assumes that the effluent rapidly mixes in a uniform volume within the cavity. Turbulence within the wake cavity will produce a relatively constant pollutant concentration within this region. Experimental evidence indicates that this assumption will give conservative predictions of ground-level concentrations in most cases.

For distances beyond the wake cavity, surface $\chi / Q$ values will contain a component from the elevated plume $(\chi / Q)_{E}$ (see Eq. 1) and from the area source of material trapped within the cavity $(\chi / Q)_{T}$. Following Hosker (1984), this is expressed as:

$$
\frac{\chi}{Q}=(1-f)\left(\frac{\chi}{Q}\right)_{E}+f\left(\frac{\chi}{Q}\right)_{T}
$$

Meroney (1982b) proposed an empirical expression for $(\chi / Q)_{T}$ as:

$$
\left(\frac{\chi}{Q}\right)_{T}=\left(\frac{\chi}{Q}\right)_{0} \exp \left[-0.5\left(\frac{\chi}{Q}\right)_{0} \pi H W U_{s}\left(\frac{h}{H}\right)^{2}\right]
$$

where the centerline ground-level plume concentration is

$$
\left(\frac{\chi}{Q}\right)_{0}=\frac{1}{U_{s}\left(\pi \sigma_{y} \sigma_{z}+0.5 H W\right)}
$$


In Equation 42, $\sigma_{y}$ and $\sigma_{z}$ are evaluated using Pasquill and Briggs formulations with $x$ equal to the distance from the start of the wake cavity. Initial values for $\sigma_{y}$ and $\sigma_{z}$ in Equation 42 are taken to be the minimum building cross-sectional dimensions.

\subsection{Dose Calculations}

At user's request inhalation and plume shine dose can be calculated. Dose factors provided in DOE (1988a and 1988b) are used. Per ICRP 30, (ICRP 1979) the DOE tritium dose conversion factor for inhalation has been increased by $50 \%$ to include absorption through the skin. Inhalation dose is estimated by the product of the radionuclide concentration in the air that is breathed, the rate at which the air is breathed, and a factor to convert intake quantities to dose. The inhalation dose to a given individual, assuming exposure during the entire plume passage, is calculated using the following general equation:

$$
D_{i n h}=3.17 E-08\left(Q_{n}\right)\left(\frac{\chi}{Q}\right)\left(D F I_{n}\right)(B) e^{-\lambda_{n} t}
$$

where

$\begin{array}{ll}3.17 \mathrm{E}-08 & \text { conversion factor (years per second) } \\ Q_{n} & \text { total release }(\mathrm{Ci}) \\ \chi / Q & \text { relative concentration at receptor }\left(\mathrm{s} / \mathrm{m}^{3}\right) \\ D F I_{n} & \text { effective dose equivalent factor for inhalation }(\mathrm{rem} / \mathrm{Ci}) \\ B & \text { adult maximum breathing rate }\left(\mathrm{m}^{3} / \mathrm{yr}\right) \\ \lambda_{n} & \text { decay constant }(1 / \mathrm{s}) \\ t & \text { travel time from release to receptor }(\mathrm{s})\end{array}$

The uniform plume model assumes that the exposed individual is located in a time integrated uniform concentration of a given nuclide throughout the infinite hemisphere above ground level. The gamma-shine external dose is therefore directly proportional to the integral air concentration and is determined by multiplying the integral concentration by an infinite-plume shine dose factor. The external dose for a given nuclide, $n$, is expressed as:

$$
D_{P S}=\left(\frac{\chi}{Q}\right)\left(Q_{n}\right)\left(D F S_{n}\right) e^{-\lambda_{n} t}
$$

where

$\chi / Q \quad$ relative air concentration at the receptor $\left(\mathrm{s} / \mathrm{m}^{3}\right)$

$Q_{n} \quad$ total release of nuclide n (Ci) 


\author{
$D F S_{n} \quad$ shine dose factor for nuclide $\mathrm{n}\left(\mathrm{mrem} / \mathrm{s}\right.$ per $\left.\mathrm{Ci} / \mathrm{m}^{3}\right)$ \\ $\lambda_{n} \quad$ decay constant for nuclide $\mathbf{n}\left(\mathrm{s}^{-1}\right)$ \\ $t \quad$ transit time between release and exposure (s)
}

A library of dose factors for 496 radionuclides is contained under the file name "Dose Factor" and is available for inspection by the user. Doses are calculated only for the radionuclides that are entered (no ingrowth is considered). The user should enter the associated progeny as appropriate.

\title{
3.0 VERIFICATION OF CALCULATIONS
}

Strict comparisons were made between VENTSAR and VENTSAR XL to ensure proper application of methodologies within the spreadsheet model. First, each of the test cases previously used for VENTSAR were duplicated using VENTSAR XL. Input for each of the test cases is shown in Appendix B. An additional set of four test cases were executed using VENTSAR XI and the results were compared with results from VENTSAR. These additional test cases are shown in Appendix B. Hand calculations also were performed to demonstrate certain aspects of the code.

\subsection{Comparison with Original Test Cases}

Results from VENTSAR XL are compared with results from VENTSAR test cases. VENTSAR had a default number of increments set at 200. Results are shown here for a select number of points. Positions were chosen in relation to building structure. If a smaller number of increments are used results may not be identical beyond the end of the building. The results may differ because the fraction of the plume that is trapped in the building wake cavity is determined at the point just beyond the building and this fraction is used within the remainder of the cavity zone (See Section 3.3).

Dose calculations were performed for two of the test cases (Case 3 and Case 6). Since dose calculations were not performed with the original version of VENTSAR, hand calculations were added to ensure the doses were calculated correctly.

In Appendix B, the results for test case 1 are shown in their entirety for the first two release heights. This test case was chosen for a complete comparison because it exercises both the plume rise and building wake effects methodologies.

Looking closely at Appendix B, differences are less than $1 \%$ for all distances except $505.0 \mathrm{~m}$ downwind which is $5.61 \%$ different for the first release height. This difference can be explained due to the difference in division in 
FORTRAN and Excel Macros. The minimum and maximum distance of interest was $10 \mathrm{~m}$ and $1000 \mathrm{~m}$, respectively, for test case one. With 200 increments the $x$ increment $(\Delta x)$ is equal to $(1000-10) / 200$ which equals 4.95 . With VENTSAR on the IBM Mainframe, FORTRAN determined this value to be 4.949999. Therefore, at increments number 100, VENTSAR and VENTSAR XL determine the distance as follows:

VENTSAR

$\mathrm{D}=\min +\mathrm{No}_{\text {. increments }} * \mathrm{x}$

$\mathrm{D}=10+100 * 4.949999$

$\mathrm{D}=504.9999 \mathrm{~m}$
VENTSAR XL

$\mathrm{D}=$ min+No. increments $* \mathrm{x}$

$\mathrm{D}=10+100 * 4.95$

$\mathrm{D}=505.0 \mathrm{~m}$

While this difference may seem inconsequential, this distance is used to determine whether or not the plume is still on top of the building. Within VENTSAR on the IBM Mainframe, $\mathrm{D}<505.0$ and therefore is on top of the building. In VENTSAR XL, D is not less than 505.0 and therefore is past the building. As a result different values of $z$ are used by VENTSAR and VENTSAR XL for this particular point and thus different answers. For all test cases, this was the only instance that this difference occurred.

Table 3 shows the results of the comparison between VENTSAR and VENTSAR XL for test case number two at several downwind distances. Both the annual average air concentration and the $99.5 \%$ air concentration are shown.

Table 3. Comparison of VENTSAR and VENTSAR XL for Test Case 2

\begin{tabular}{|c|c|c|c|c|c|c|}
\hline $\begin{array}{c}\text { Downwind } \\
\text { Distance } \\
(\mathrm{m})\end{array}$ & $\begin{array}{c}\text { VENTSAR } \\
99.5 \% \chi / \mathrm{Q} \\
\left(\mathrm{s} / \mathrm{m}^{* * 3}\right)\end{array}$ & $\begin{array}{c}\text { VENTSAR } \\
\text { Annual } \chi / \mathrm{Q} \\
\left(\mathrm{s} / \mathrm{m}^{* * 3}\right)\end{array}$ & $\begin{array}{c}\text { VENTSAR XL } \\
99.5 \% \chi / \mathrm{Q} \\
\left(\mathrm{s} / \mathrm{m}^{* * 3}\right)\end{array}$ & $\begin{array}{c}\text { ENTSAR XY } \\
\text { Annual } \chi / \mathrm{Q} \\
\left(\mathrm{s} / \mathrm{m}^{* *} 3\right)\end{array}$ & $\begin{array}{c}\% \text { Diff } \\
99.5 \% \chi / \mathrm{Q} \\
(\%)\end{array}$ & $\begin{array}{c}\% \text { Diff } \\
\text { Annual } \chi / \mathrm{Q} \\
(\%)\end{array}$ \\
\hline 10 & $0.00 \mathrm{E}+00$ & $0.00 \mathrm{E}+00$ & $0.00 \mathrm{E}+00$ & $0.00 \mathrm{E}+00$ & $0.00 \%$ & $0.00 \%$ \\
109 & $9.40 \mathrm{E}-41$ & $7.85 \mathrm{E}-32$ & $9.34 \mathrm{E}-41$ & $7.82 \mathrm{E}-32$ & $0.69 \%$ & $0.41 \%$ \\
208 & $4.39 \mathrm{E}-20$ & $1.34 \mathrm{E}-17$ & $4.37 \mathrm{E}-20$ & $1.34 \mathrm{E}-17$ & $0.40 \%$ & $-0.03 \%$ \\
307 & $1.01 \mathrm{E}-12$ & $1.07 \mathrm{E}-13$ & $1.01 \mathrm{E}-12$ & $1.07 \mathrm{E}-13$ & $-0.11 \%$ & $0.35 \%$ \\
406 & $5.59 \mathrm{E}-10$ & $4.00 \mathrm{E}-12$ & $5.59 \mathrm{E}-10$ & $4.00 \mathrm{E}-12$ & $-0.07 \%$ & $0.10 \%$ \\
505 & $9.46 \mathrm{E}-09$ & $3.98 \mathrm{E}-11$ & $9.43 \mathrm{E}-09$ & $3.98 \mathrm{E}-11$ & $-0.01 \%$ & $-0.06 \%$ \\
604 & $4.01 \mathrm{E}-08$ & $1.53 \mathrm{E}-10$ & $4.01 \mathrm{E}-08$ & $1.53 \mathrm{E}-10$ & $-0.03 \%$ & $0.05 \%$ \\
703 & $8.99 \mathrm{E}-08$ & $3.45 \mathrm{E}-10$ & $8.99 \mathrm{E}-08$ & $3.45 \mathrm{E}-10$ & $0.05 \%$ & $0.11 \%$ \\
802 & $1.45 \mathrm{E}-07$ & $5.99 \mathrm{E}-10$ & $1.45 \mathrm{E}-07$ & $5.99 \mathrm{E}-10$ & $0.34 \%$ & $-0.03 \%$ \\
901 & $1.93 \mathrm{E}-07$ & $9.11 \mathrm{E}-10$ & $1.93 \mathrm{E}-07$ & $9.11 \mathrm{E}-10$ & $-0.11 \%$ & $0.01 \%$ \\
\hline
\end{tabular}

The results for the remaining test cases are shown in Appendix B. Differences were less than $1 \%$ for all distances. If a specific stability class and wind speed was selected then only the $\chi / Q$ corresponding to the particular combination is shown because no annual average is calculated. 


\subsection{Comparison with Additional Test Cases}

Four additional test cases were developed to test various aspects of the spreadsheet. The input for these test cases and the results of the comparison with VENTSAR XL are shown in Appendix C. Differences were less than $0.01 \%$ for all distances. Cases 9 and 10 include dose calculations and verification of these values was done by hand calculations.

\subsection{Plume Rise Hand Calculations}

Table 4 shows the input parameters that were used in the spreadsheet to verify the plume rise module. Variables were chosen at random within the ranges of validity. Table 5 shows a comparison of hand calculations and VENTSAR XL results for several downwind distances. Differences are less than 1\% for all distances shown. See Appendix D, Section 1 for the actual hand calculations.

Table 4. Input parameters for Plume Rise Verification.

\begin{tabular}{|l|l|}
\hline Parameter & Input \\
\hline Area or Release Location & A \\
Building Height & $0.0 \mathrm{~m}$ \\
Building Width & $0.0 \mathrm{~m}$ \\
Building Length & $0.0 \mathrm{~m}$ \\
Penthouse Height & $0.0 \mathrm{~m}$ \\
Penthouse Width & $0.0 \mathrm{~m}$ \\
Penthouse Length & $0.0 \mathrm{~m}$ \\
Penthouse Distance & $0.0 \mathrm{~m}$ \\
Minimum Distance of Interest & $10 \mathrm{~m}$ \\
Maximum Distance of Interest & $1010 \mathrm{~m}$ \\
Number of Increments & 100 \\
Compass Sector of Building Location & 3 \\
Distance of Vent from Roof Edge & 0.0 \\
Vent Height & $20.0 \mathrm{~m}$ \\
Radioactive Calculation? & $\mathrm{No}$ \\
Release Rate & 0 \\
Mole Fraction of Pollutant & $1.8 \mathrm{E}-03$ \\
Vent Gas Flow Rate & $50 \mathrm{~m} 3 / \mathrm{s}$ \\
Averaging Option & $\mathrm{No}$ \\
Wind Speed & $6 \mathrm{~m} / \mathrm{s}$ \\
Stability Class & $4(\mathrm{D})$ \\
Vent Diameter & $1.0 \mathrm{~m}$ \\
Vent Gas Molecular Weight & 78.12 \\
Vent Gas Air Temperature & $40 \mathrm{C}$ \\
Air Temperature & $20 \mathrm{C}$ \\
Dose Calculation & $\mathrm{N}$ \\
Breathing Rate & $\mathrm{NA}$ \\
Radionuclide & $\mathrm{Ci}$ \\
NA & $\mathrm{NA}$ \\
\hline
\end{tabular}


Table 5. Hand Calculations for Plume Rise Verification

\begin{tabular}{|c|c|c|c|}
\hline $\begin{array}{l}\text { Downwind } \\
\text { Distance }(\mathrm{m})\end{array}$ & $\begin{array}{l}\text { Relative Air } \\
\text { Concentration }\left(\mathrm{s} / \mathrm{m}^{3}\right) \\
\text { VENTSAR XL }\end{array}$ & $\begin{array}{l}\text { Relative Air } \\
\text { Concentration }\left(\mathrm{s} / \mathrm{m}^{3}\right) \\
\text { Hand Calculations }\end{array}$ & $\begin{array}{l}\text { Percent } \\
\text { Difference }\end{array}$ \\
\hline 10 & $0.00 \mathrm{E}+00$ & $0.00 \mathrm{E}+00$ & $0.0 \%$ \\
200 & $8.16 \mathrm{E}-17$ & $8.21 \mathrm{E}-17$ & $-0.6 \%$ \\
1000 & $4.40 \mathrm{E}-07$ & $4.41 \mathrm{E}-07$ & $-0.2 \%$ \\
\hline
\end{tabular}

\subsection{Building Wake Effects Verification}

Table 6 shows the input parameters that were used to verify the building wake effects module. Figure 3 shows a side view of the building and the places at which calculations were performed to verify the concentrations. These locations were selected to ensure all zones were considered. Table 7 shows the results of the comparison. Differences are less than $1 \%$. See Appendix A, Section 2 for the hand calculations.

Figure 3. Concentration locations for Building Wake Effects Verification

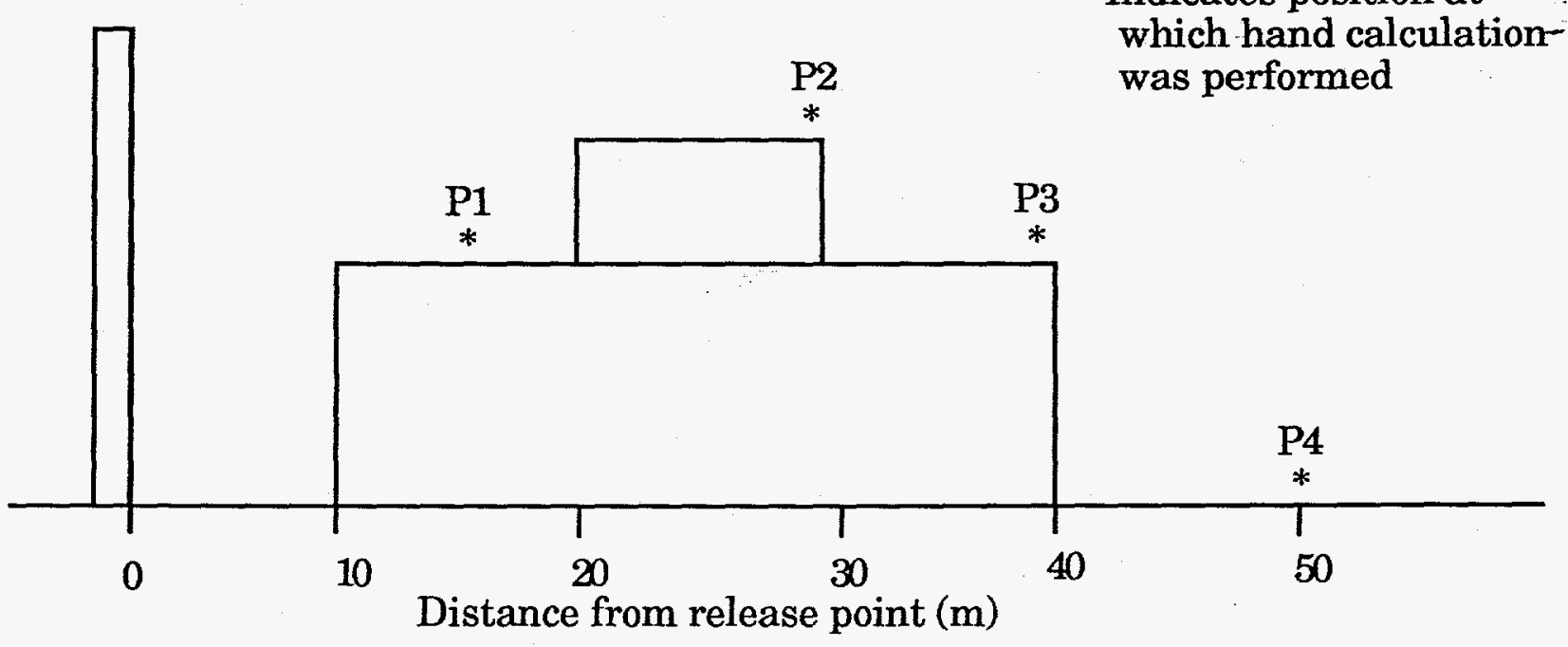


Table 6. Input parameters for Building Wake Effects Verification

\begin{tabular}{|l|l|}
\hline Parameter & Input \\
\hline Area or Release Location & $\mathrm{K}$ \\
Building Height & $10.0 \mathrm{~m}$ \\
Building Width & $20.0 \mathrm{~m}$ \\
Building Length & $30.0 \mathrm{~m}$ \\
Penthouse Height & $5.0 \mathrm{~m}$ \\
Penthouse Width & $10.0 \mathrm{~m}$ \\
Penthouse Length & $10.0 \mathrm{~m}$ \\
Penthouse Distance & $10.0 \mathrm{~m}$ \\
Minimum Distance of Interest & $10 \mathrm{~m}$ \\
Maximum Distance of Interest & $50 \mathrm{~m}$ \\
Number of Increments & 8 \\
Compass Sector of Building Location & 3 \\
Distance of Vent from Roof Edge & -10.0 \\
Vent Height & $20.0 \mathrm{~m}$ \\
Radioactive Calculation? & $\mathrm{Yes}$ \\
Release Rate & $1 \mathrm{Ci} / \mathrm{min}$ \\
Mole Fraction of Pollutant & 0 \\
Vent Gas Flow Rate & 0 \\
Averaging Option & $\mathrm{No}$ \\
Wind Speed & $6 \mathrm{~m} / \mathrm{s}$ \\
Stability Class & $4(\mathrm{D})$ \\
Vent Diameter & $0.1 \mathrm{~m}$ \\
Vent Gas Molecular Weight & 78.12 \\
Vent Gas Temperature & 0 \\
Ambient Air Temperature & 0 \\
Dose Calculation & $\mathrm{N}$ \\
Breathing Rate & $\mathrm{NA}$ \\
Radionuclide & $\mathrm{Ci}$ \\
\hline NA & $\mathrm{NA}$ \\
\hline
\end{tabular}

Table 7. Hand Calculations for Building Wake Effects Verification

\begin{tabular}{|l|c|c|c|}
\hline $\begin{array}{l}\text { Downwind } \\
\text { Distance }(\mathrm{m}) \\
\text { (Position) }\end{array}$ & $\begin{array}{l}\text { Relative Air } \\
\text { Concentration }\left(\mathrm{s} / \mathrm{m}^{3}\right) \\
\text { VENTSAR XL }\end{array}$ & $\begin{array}{l}\text { Relative Air } \\
\text { Concentration }\left(\mathrm{s} / \mathrm{m}^{3}\right) \\
\text { Hand Calculations }\end{array}$ & $\begin{array}{c}\text { Percent } \\
\text { Difference }\end{array}$ \\
\hline 15 (P1) & $1.13 \mathrm{E}-14$ & $1.13 \mathrm{E}-14$ & $0.0 \%$ \\
30 (P2) & $4.69 \mathrm{E}-05$ & $4.68 \mathrm{E}-05$ & $0.2 \%$ \\
40 (P3) & $3.16 \mathrm{E}-19$ & $3.16 \mathrm{E}-19$ & $0.0 \%$ \\
50 (P4) & $8.42 \mathrm{E}-14$ & $8.36 \mathrm{E}-14$ & $0.7 \%$ \\
\hline
\end{tabular}




\subsection{Verification of Plume Rise and Building Options Combined}

A case with both a simple building and plume rise was analyzed. The input parameters for this comparison are shown in Table 8. The results of the hand calculations compared with the actual code output are shown in Table 9. The differences in relative air concentrations were $2 \%$ or less for all of the positions selected. These differences are due to rounding. When the results are large negative exponents slight differences in the exponents can result in magnified differences in the results. A comparison of the dose calculations is shown in Table 10. See Appendix D, Section 3 for an example of the hand calculations.

Table 8. Input parameters for Building Wake Effects and Plume Rise Verification

\begin{tabular}{|l|l|}
\hline Parameter & Input \\
\hline Area or Release Location & $\mathrm{A}$ \\
Building Height & $10.0 \mathrm{~m}$ \\
Building Width & $20.0 \mathrm{~m}$ \\
Building Length & $30.0 \mathrm{~m}$ \\
Penthouse Height & $0.0 \mathrm{~m}$ \\
Penthouse Width & $0.0 \mathrm{~m}$ \\
Penthouse Length & $0.0 \mathrm{~m}$ \\
Penthouse Distance & $0.0 \mathrm{~m}$ \\
Minimum Distance of Interest & $10 \mathrm{~m}$ \\
Maximum Distance of Interest & $1010 \mathrm{~m}$ \\
Number of Increments & 200 \\
Compass Sector of Building Location & 3 \\
Distance of Vent from Roof Edge & -10.0 \\
Vent Height & $0.0 \mathrm{~m}$ \\
Radioactive Calculation? & Yes \\
Release Rate & $1 \mathrm{Ci} / \mathrm{min}$ \\
Mole Fraction of Pollutant & 0 \\
Vent Gas Flow Rate & 50 \\
Averaging Option & $\mathrm{No}$ \\
Wind Speed & $4 \mathrm{~m} / \mathrm{s}$ \\
Stability Class & $3(\mathrm{C})$ \\
Vent Diameter & $1 \mathrm{~m}$ \\
Vent Gas Molecular Weight & 78.12 \\
Vent Gas Temperature & $40 \mathrm{C}$ \\
Ambient Air Temperature & $20 \mathrm{C}$ \\
Dose Calculation & Y \\
Breathing Rate & 10500 \\
Radionuclide & $\mathrm{Ci}$ \\
\hline H-3 & 3000 \\
Cs-137 & 5000 \\
Ba-137m & 5000 \\
\hline
\end{tabular}


Table 9. Hand Calculations of Relative Air Concentrations

\begin{tabular}{|c|c|c|c|}
\hline $\begin{array}{l}\text { Downwind } \\
\text { Distance }(\mathrm{m})\end{array}$ & $\begin{array}{l}\text { Relative Air } \\
\text { Concentration }\left(\mathrm{s} / \mathrm{m}^{3}\right) \\
\text { VENTSAR XL }\end{array}$ & $\begin{array}{l}\text { Relative Air } \\
\text { Concentration }\left(\mathrm{s} / \mathrm{m}^{3}\right) \\
\text { Hand Calculations }\end{array}$ & $\begin{array}{c}\text { Percent } \\
\text { Difference }\end{array}$ \\
\hline 30 & $7.78 \mathrm{E}-73$ & $7.66 \mathrm{E}-73$ & $1.5 \%$ \\
45 & $9.60 \mathrm{E}-69$ & $9.51 \mathrm{E}-69$ & $1.0 \%$ \\
100 & $9.82 \mathrm{E}-23$ & $9.70 \mathrm{E}-23$ & $1.2 \%$ \\
500 & $1.89 \mathrm{E}-07$ & $1.88 \mathrm{E}-07$ & $0.5 \%$ \\
\hline
\end{tabular}

Table 10. Hand Calculations of Dose Predictions

\begin{tabular}{|r|c|c|c|}
\hline $\begin{array}{l}\text { Downwind } \\
\text { Distance } \\
\text { (m) }\end{array}$ & $\begin{array}{l}\text { VENTSAR XL } \\
\text { Calculated Dose } \\
\text { (mrem) }\end{array}$ & $\begin{array}{l}\text { Hand Calculated } \\
\text { Dose } \\
\text { (mrem) }\end{array}$ & $\begin{array}{c}\text { Percent } \\
\text { Difference }\end{array}$ \\
\hline 30 & $4.19 \mathrm{E}-65$ & $4.12 \mathrm{E}-65$ & $1.7 \%$ \\
45 & $5.16 \mathrm{E}-61$ & $5.12 \mathrm{E}-61$ & $0.8 \%$ \\
100 & $5.28 \mathrm{E}-15$ & $5.22 \mathrm{E}-15$ & $1.1 \%$ \\
500 & $1.01 \mathrm{E}+01$ & $1.01 \mathrm{E}+01$ & $0.0 \%$ \\
\hline
\end{tabular}

\subsection{EXECUTING VENTSAR XL}

VENTSAR XL is a calculational spreadsheet that was created using Microsoft Excel Version 4.0. Macros, the Excel programming language, is used. Later versions of Microsoft Excel will also support this program. The user simply changes the required inputs in the "VENTSAR XL" file and clicks a button (CALCULATE) to run the models. "VENTSAR XL" and "MACRO $\mathrm{XL}$ " can only be opened as a read only file, so when the prompt asks, open as "Read Only." Once the calculations are complete, the user can use "Save As" to keep a copy of the results. Certain cells have been locked so inadvertent changes cannot be made by the user.

Figure 4 shows a sample page of input. The CALCULATE button is contained in the upper left hand of the computer screen. Once a Macro has begun to execute, the user may work within applications other than Excel by clicking on the desktop. The user may stop execution at any time by holding down the apple key ( $)$ and the period key (.) for Macintosh users or pressing Escape for IBM users.

Input parameters are discussed and their ranges of validity are noted. Valid ranges of input are shown to the right of the parameter in the spreadsheet. If the user enters a value that is not valid, column E will show "INVALID." The spreadsheet will not execute if there is an "INVALID" anywhere in column $\mathrm{E}$ of the data spreadsheet. 
Figure 4. Input Template for VENTSAR XL

\section{VENTSAR XL}

TITLE

Name and Phone Number

Release Location

(A,C,D, F, H, K, P, or O for other)

Grid Coordinates Easting Northing

\section{Building Dimensions}

Building Height

Building Width

Building Length

Penthouse Height

Penthouse Width

Penthouse Length

Distance to Penthouse on Rooftop (Negative indicates on roof)

Minimum Distance of Interest

Maximum Distance of Interest

Number of Increments

Compass Sector of Building (1-N, 2-NNE, ...)

Distance of Vent from Roof Edge (negative is upwind)

Vent Height

Radioactive Calculations $(\mathrm{Y}$ or $\mathrm{N})$

If yes Release Rate

If No Mole Fraction of Vent Gas

Vent Gas Flow Rate

Averaging Option ( $\mathrm{Y}$ or $\mathrm{N}$ )

If YES Specify Probability Level

If NO Wind speed at Vent Height

Stability Class (1-7 to A-G)

Plume Rise ( $\mathrm{Y}$ or $\mathrm{N}$ )

Vent Diameter

Gas Molecular Weight

Vent Gas Temperature

Ambient Air Temperature

Calculate Dose( $\mathrm{Y}$ or $\mathrm{N})$

Breathing Rate

$P^{\text {Units } \quad \text { VALID RANGE }}$

$\mathrm{ft}$

$\mathrm{ft}$

$10 \mathrm{~m}$

$20 \mathrm{~m}$

$30 \mathrm{~m}$

$1 \mathrm{~m}$

$2 \mathrm{~m}$

$3 \mathrm{~m}$

$5 \mathrm{~m}$

$10 \mathrm{~m}$

$1010 \mathrm{~m}$

10

16

$-500$

$50 \mathrm{~m}$

$\mathrm{N}$

$1 \mathrm{Ci} / \mathrm{min}$

1.0E-06

$500 \mathrm{~m} 3 / \mathrm{s}$ $Y$

0.005

$4.5 \mathrm{~m} / \mathrm{s}$

4

y

210

$20 \mathrm{C}$

$15 \mathrm{C}$

$Y$

$10500 \mathrm{~m} 3 / \mathrm{yr}$

8000

20000

1000

$0.001 \quad 0.5$

0.1

Radionuclide

H-3

$\mathrm{Ci}$ 


\section{RELEASE LOCATION}

Enter the meteorological file name or enter "SRS" and enter the coordinates of the release below. The meteorological file must be placed in the same folder as the VENTSAR XL files. If the meteorological file can not be found, a message will be displayed during the execution of the Macro and the Macro will be terminated. If "SRS" is chosen, the exact location of the release must be specified using the next two input lines. Site coordinates must be used to input the grid location. This input is entered to determine which meteorological data set is used for the remainder of the calculations. See Parker (1992) and Weber (1993) for information on the SRS meteorological data bases.

\section{BUILDING DIMENSIONS}

Enter the dimensions of the building and penthouse in meters. Figure 2 shows a three-dimensional view of the building dimensions with the wind direction toward the face of the building. The assumed direction of the wind is important with respect to the building dimensions that are used. The variable XSTP represents the distance to the penthouse from the edge of the building. The valid range for this parameter is such that the penthouse will still fit on top of the building. If no penthouse is included, set all of the penthouse parameters to zero. Calculations may also be done without a building by setting all of the parameters to zero.

\section{DISTANCES FOR CALCULATIONS TO BE PERFORMED}

Enter the minimum and maximum distances for which the calculations are to be performed. Valid range is from 10 to $100,000 \mathrm{~m}$ and the maximum must be greater than the minimum or an error will result. These two inputs set the bounds for the distances at which the calculations will be performed. The next input specifies the number of increments that the above bracketed distance will be divided into. Valid range is 1 to 200 . This parameter will greatly affect the amount of time that it takes the Macro to execute, so choose the smallest number possible that will still give you the desired results. If building wake effects are to be considered, there should be several increments just beyond the building to ensure the proper fraction of the plume is entrained.

\section{SECTOR DESIGNATION}

Enter the sector that corresponds to the direction in which the building lies with respect to the release location (1-N, 2-NNE, 3-NE, ...). Sector selection is important if meteorological exceedance probability is specified because meteorological frequency data will be chosen based on this input. Figure 5 shows a pictorial view of the sector notation for a sample release from $\mathrm{H}$ Area within SRS. The dotted lines represent the center of the sector. If a given wind speed and stability class is used, sector designation is unimportant since no meteorological data files are accessed. 


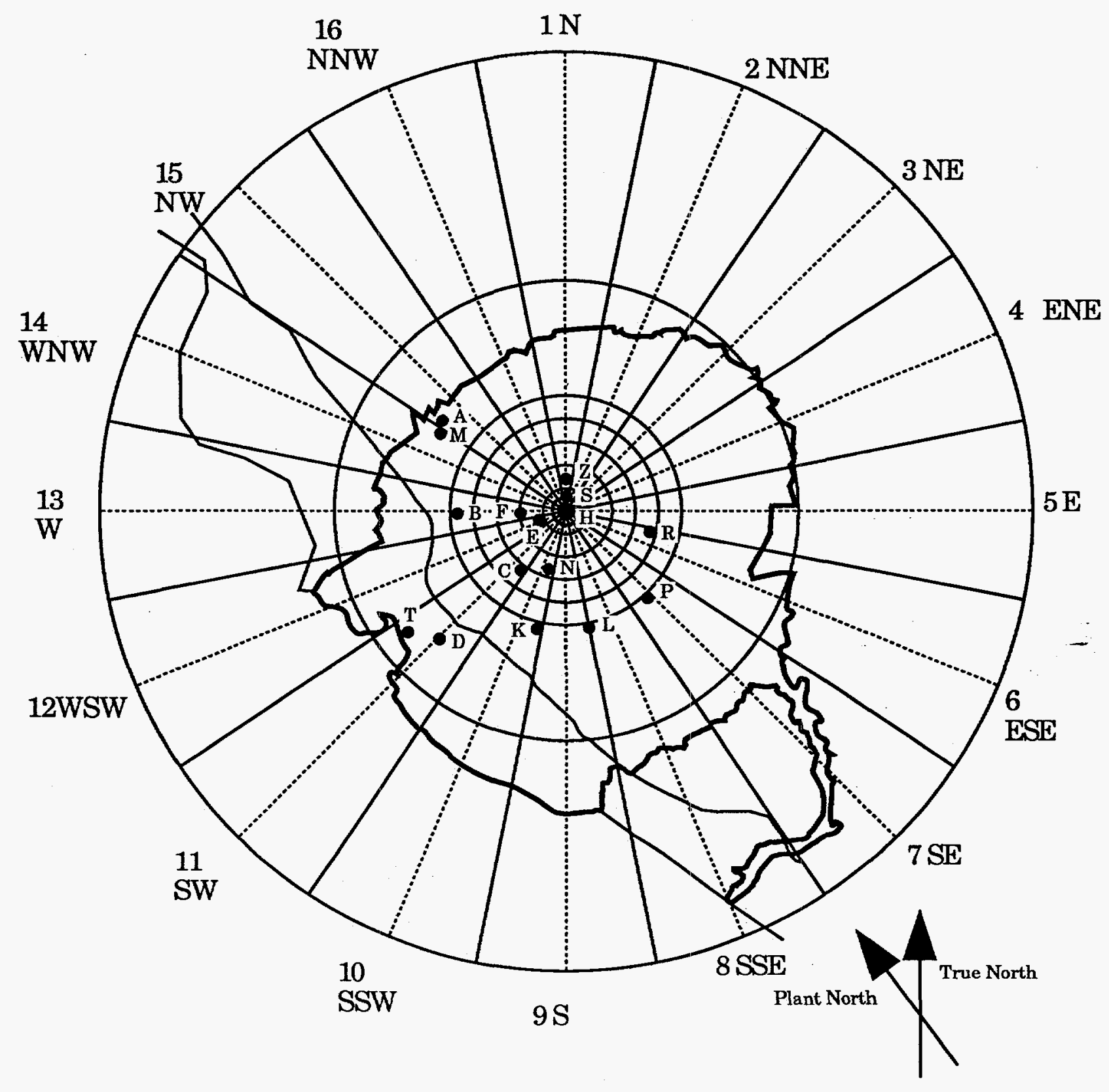

Figure 5. Sector Notation (Sector represents direction wind moves towards.) 


\section{DISTANCE TO ROOF EDGE}

The distance from the roof edge to the vent or release location is entered here. A negative number indicates that the vent is upwind of the building while a positive number indicates the vent is located on the roof. Figure 6 shows a simple representation of the side view of a building with two positions noted. For a release location in position $A$, an input of "-10.0" would be used whereas for position B, "5.0" would be entered. Valid range is -1000.0 to 1000.0 meters.

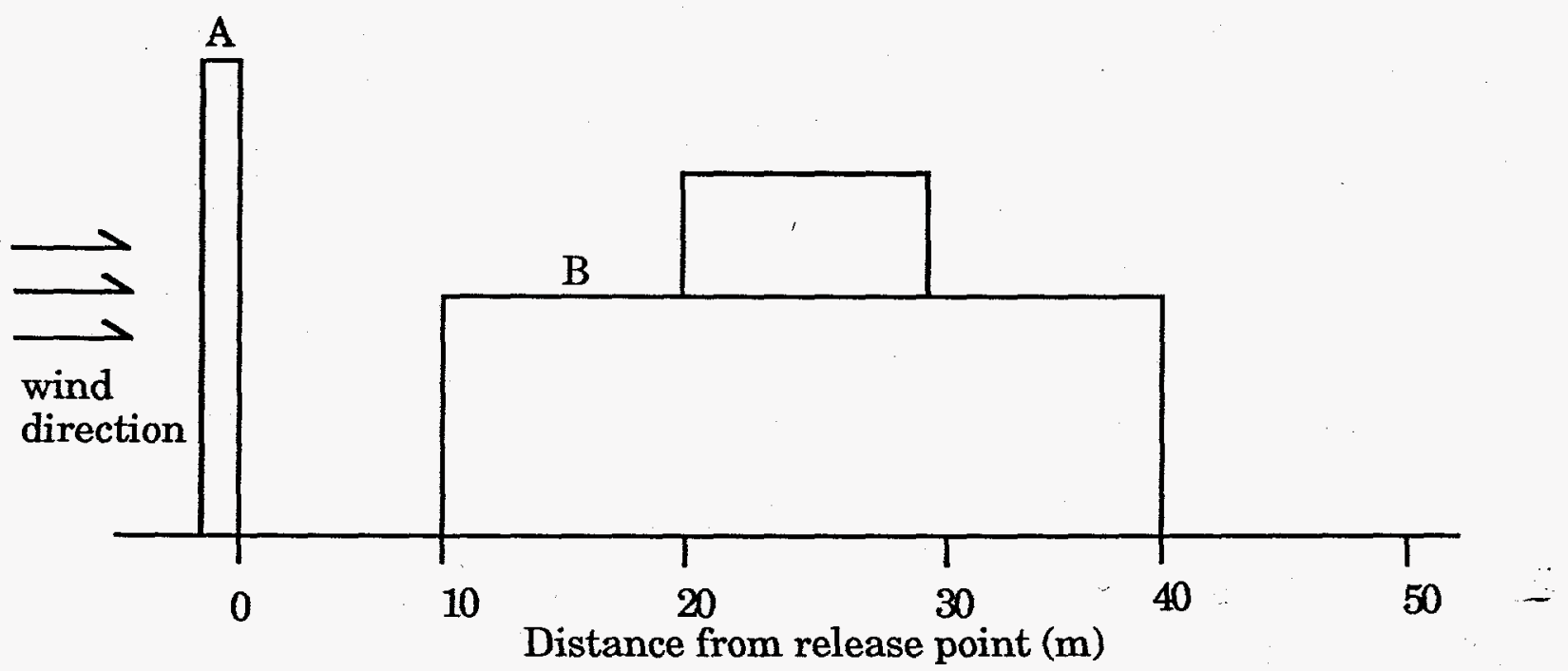

Figure 6. Release Location Explanation for Input

\section{RELEASE HEIGHT}

Enter the height of the release. Valid range is 0.0 to $500 \mathrm{~m}$.

\section{RADIOACTIVE CALCULATION}

Enter " $\mathrm{Y}$ " if the calculation is for radioactive emissions and " $\mathrm{N}$ " if it is not. If "N" is selected, enter the component mole fraction next.

\section{VENT GAS FLOW RATE}

Enter the rate at which the gas is exiting the stack or vent in $\mathrm{m}^{3 / \mathrm{s}}$. Valid range is from 0 to $1000 \mathrm{~m}^{3} / \mathrm{s}$. 


\section{AVERAGING OPTION}

Enter "Y" for a meteorological exceedance probability to be specified. For meteorological conditions not exceeded $99.5 \%$ of the time, "0.005" would be entered. If " $\mathrm{N}$ " is entered, the wind speed (valid range is $0.1-15 \mathrm{~m} / \mathrm{s}$ ) and stability class must be specified in the following two lines. Enter the wind speed and a number that corresponds to the stability class (A - G corresponds to 1 - 7). These two statements may be left blank if the averaging option is selected.

\section{PLUME RISE}

Enter " $\mathrm{Y}$ " for yes and " $\mathrm{N}$ " for no. If yes is entered and plume rise is considered, the following four lines must have input. If no is entered, plume rise will not be considered, however the next line (diameter) must be completed. If plume rise is considered, enter the molecular weight of the gas. The molecular weight of the air and gas mixture will be calculated and used for the remaining calculations. Enter the temperature of the vent gas and the ambient air in degrees Celsius.

\section{CALCULATE DOSE}

Enter " $Y$ " for yes and "N" for no. The user may only enter yes if the release was noted as radioactive above. If dose calculations are desired, the user is to enter the breathing rate of the individual. Valid range is from $8000 \mathrm{~m}^{3} / \mathrm{yr}$ to $20000 \mathrm{~m}^{3} / \mathrm{yr}$. Next the radionuclides are entered with the respective release amount. The radionuclide should be entered in the form XX-NN. Where XX is the chemical name and $\mathrm{NN}$ is the isotope number. If it is not entered correctly, the spreadsheet will not be able to locate the radionuclide in the dose file and an error will result. Browse the "Dose Factor" file for a complete list of radionuclides.

\subsection{VENTSAR XI OUTPUT}

Sample portions of the output are displayed and discussed. A copy can be generated using the input parameters shown in Figure 1. A printout of the output can be made by clicking on the "PRINT" button at the top of the "VENTSAR XL" file.

Output headings will vary depending on whether the release is chemical or radioactive. Figure 5 shows part of the results for a radioactive release. The titles above each of the columns are self explanatory. If a specific wind speed and stability class is selected, the annual average $\chi / Q$ will not be calculated. 
Figure 7. Sample Output for VENTSAR XL

\begin{tabular}{|c|c|c|c|}
\hline & $99.50 \%$ & Pollutant & Annual \\
\hline & $\mathrm{x} / \mathrm{Q}$ & Concentration & Average \\
\hline Distance $(\mathrm{m})$ & $\left(\mathrm{s} / \mathrm{m}^{\wedge} 3\right)$ & (pCi/cc) & $\left(\mathrm{s} / \mathrm{m}^{\wedge} 3\right)$ \\
\hline 10.0 & $0.00 \mathrm{E}+00$ & $0.00 \mathrm{E}+00$ & $0.00 \mathrm{E}+00$ \\
\hline 110.0 & $2.42 \mathrm{E}-45$ & $1.19 \mathrm{E}-42$ & $3.53 \mathrm{E}-24$ \\
\hline 210.0 & $1.63 \mathrm{E}-18$ & $7.99 \mathrm{E}-16$ & $9.52 \mathrm{E}-15$ \\
\hline 310.0 & $3.69 \mathrm{E}-15$ & $1.82 \mathrm{E}-12$ & $1.69 \mathrm{E}-12$ \\
\hline 410.0 & $6.83 \mathrm{E}-12$ & $3.35 \mathrm{E}-09$ & $1.87 \mathrm{E}-11$ \\
\hline 510.0 & $3.67 \mathrm{E}-10$ & $1.80 \mathrm{E}-07$ & $6.33 \mathrm{E}-11$ \\
\hline 610.0 & $2.21 \mathrm{E}-09$ & $1.09 \mathrm{E}-06$ & $1.27 \mathrm{E}-10$ \\
\hline 710.0 & $8.03 \mathrm{E}-09$ & $3.95 \mathrm{E}-06$ & $2.15 \mathrm{E}-10$ \\
\hline 810.0 & $2.66 \mathrm{E}-08$ & $1.31 \mathrm{E}-05$ & $4.10 \mathrm{E}-10$ \\
\hline 910.0 & $5.83 \mathrm{E}-08$ & $2.87 \mathrm{E}-05$ & $6.87 \mathrm{E}-10$ \\
\hline 1010.0 & $9.91 \mathrm{E}-08$ & $4.87 \mathrm{E}-05$ & $1.02 \mathrm{E}-09$ \\
\hline
\end{tabular}

\subsection{CONCLUSIONS}

VENTSAR XL has been verified and is operating as expected. Hand calculations and comparisons with the IBM version of VENTSAR demonstrate that the spreadsheet is properly utilizing methodologies. Use of the spreadsheet version will allow for ease in input preparation and immediate display of output. 


\subsection{REFERENCES}

Briggs, G.A. , 1969: Plume Rise, Air Resources Atmospheric Turbulence and Diffusion Laboratory, TID-25075, USAEC, Division of Technical Information.

Briggs, G.A., 1973: "Diffusion Estimation for Small Emissions", in Environmental Research Laboratory, Air Resources Atmospheric Turbulence and Diffusion Laboratory, Annual Report, ATDL-106, USDOC-NOAA.

Briggs, G.A., 1976: "Plume Rise Predictions", Lectures on Air Pollution and Environmental Impact Analyses, American Meteorological Society, Boston, Mass.

Briggs, G.A., 1984: "Plume Rise and Buoyancy Effects", Atmospheric Science and Power Production, DOE/TIC-27601, p 327.

DOE, 1988a: Internal Dose Conversion Factors for Calculation of Dose to the Public, DOE/EH-0071, Washington, DC.

DOE, 1988b: External Dose-Rate Conversion Factors for Calculation of Dose to the Public, DOE/EH-0071, Washington, DC.

Hanna, S. R., 1982: and G. A. Briggs, and R. P. Hosker, Jr., Handbook on Atmospheric Diffusion. DOE/TIC-11223 (DE82002045) Technical Information Center, USDOE.

Hosker, R.P., 1984: "Flow and Diffusion Near Obstacles", Atmospheric Science and Power Production, DOE/TIC-27601, p 241.

ICRP 1979: International Commission on Radiological Protection, Limits for Intake of Radionuclides by Workers, Publication 30, Part 1, Pergamon Press, Vol. 2, No.3.

Meroney, R.N., 1982a: "Wind-Tunnel Experiments on Dense Gas Dispersion. Journal of Hazardous Materials", Journal of Hazardous Materials 6, p 85 .

Meroney, R.N., 1982b: Engineering Meteorology, E.J. Plate, Editor, Elsevier Scientific Publishing Company, New York.

Parker, M.J., 1992: The 1987-1991 Savannah River Site Meteorological Data Base(U), USDOE Report WSRC-RP-92-598, Westinghouse Savannah River Company, Aiken, SC.

Pasquill, F., 1961: "The Estimation of the Dispersion of Windborne Material", Meteorological Magazine 90, p 33. 
Pasquill, F., 1976: Atmospheric Dispersion Parameters in Gaussian Plume Modeling: Part II. Possible Requirements for Change in the Turner Workbook Values, EPA Report EPA-600/4-76306, US Environmental Protection Agency.

Smith, F.G. and A.H. Weber 1983: A Computer Code for the Estimation of Pollutant Concentrations on or Near Buildings, National Technical Information Service, DP-1668, Springfield, VA.

Snyder, W.H. 1972: "Similarity Criteria for the Application of Fluid Models to the Study of Air Pollution Meteorology", Boundary-Layer Meteorology 3, D. Reidel Publishing Company, Dordrecht-Holland, $\mathrm{p}$ 113.

Snyder, W.H. 1991: "Fluid Modeling Simulation of Stack-Tip Downwash for Neutrally Buoyant Plumes", Atmospheric Environment, Volume 25A, No $12, \mathrm{p} 2937$.

Weber, A.H., 1993: Comparison of Savannah River Site's Meteorological Databases(U), USDOE Report WSRC-RP-93-269, Westinghouse Savannah River Company, Aiken, SC.

Wilson, D.J., 1979: "Flow Patterns Over Flat-Roofed Buildings and Application to Exhaust Stack Design", ASHRAE Transactions 85, Part $2, \mathrm{p} 284$. 
APPENDIX A. METEOROLOGICAL FILE DESCRIPTION 


\section{APPENDIX A. METEOROLOGICAL FILE DESCRIPTION}

A sample page of the meteorological data file accessed by VENTSAR XL is shown in Figure A1. If the user wishes to create a meteorological file, use an existing file and change the numbers as necessary and then "Save As" the new file name. This will ensure that the user is applying the correct format. The total number of records is shown in the top left hand corner. Wind speed are reciprocal averages for the wind category shown. If the user wishes to use less wind speed classes or stability categories the remaining classes can be filled in with zeroes.

Meteorological data files for use with VENTSAR XL exist for the following SRS areas (See figure 3): A, C, D, F, H, K, L, and P. The meteorological data are obtained from hourly averages of measurements made at 1.5 seconds intervals. The files contain joint frequency distributions and reciprocal average wind velocities categorized by wind direction, speed, and stability class. Reciprocal average wind speeds are utilized since air concentration is inversely proportional to wind speed. Table A1 provides wind speed category definitions for SRS data. See Parker (1992) and Weber (1993) for more details on the wind statistics obtained from the SRS area meteorological towers. These data files have gone through rigorous quality assurance processes by the Environmental Transport Group.

It is recommended that once a file is corrected that it is protected to avoid inadvertent changes that may occur when opening and examining files. As seen in the SRS meteorological files, the password is recorded at the top. 


\begin{tabular}{|c|c|c|c|c|c|c|c|c|c|c|c|c|c|c|c|}
\hline \multirow{3}{*}{$\begin{array}{r}\text { A-Area } \\
39224 \\
\end{array}$} & \multicolumn{15}{|c|}{ Meteorological Data (1987-1991) } \\
\hline & & \multicolumn{4}{|c|}{ PASSWORD=METDATA } & & & & & & & & & & \\
\hline & & & & & & & & & & & & & & & \\
\hline Wind & $S$ & \multicolumn{5}{|c|}{ Observation Distribution } & & Wind & $S$ & \multicolumn{6}{|c|}{ Average Wind Speeds (UA) (meters/sec) } \\
\hline Speed & & \multicolumn{4}{|c|}{ Stability Category } & & & Speed & & & \multicolumn{3}{|c|}{ Stability Category } & & \\
\hline Categor & A & $\mathrm{B}$ & $\mathrm{C}$ & $D$ & $E$ & $F$ & $\mathrm{G}$ & Category & A & $\mathrm{B}$ & $\mathrm{C}$ & $D$ & $E$ & $\mathrm{~F}$ & G \\
\hline 1 & 127 & 23 & 7 & 9 & 1 & 1 & 1 & 1 & 1.25 & 1.53 & 1.54 & 0.81 & 0.40 & 1.50 & 1.77 \\
\hline 2 & 336 & 77 & 51 & 35 & 17 & 4 & 6 & 2 & 2.74 & 2.83 & 2.66 & 2.95 & 3.11 & 3.23 & 3.35 \\
\hline 3 & 191 & 27 & 30 & 18 & 8 & 7 & 2 & 3 & 4.68 & 4.70 & 4.67 & 4.78 & 4.74 & 4.77 & 5.17 \\
\hline 4 & 24 & 3 & 6 & 0 & 0 & 0 & 0 & 4 & 6.47 & 6.43 & 6.36 & 0.00 & 0.00 & 0.00 & 0.00 \\
\hline 5 & 0 & 1 & 1 & 0 & 1 & 0 & 0 & 5 & 0.00 & 9.21 & 8.48 & 0.00 & 7.77 & 0.00 & 0.00 \\
\hline 6 & 0 & 0 & 0 & 0 & 0 & 0 & 0 & 6 & 0.00 & 0.00 & 0.00 & 0.00 & 0.00 & 0.00 & 0.00 \\
\hline & & & & & & & & & & & & & & & \\
\hline Wind & SSW & \multicolumn{5}{|c|}{ Observation Distribution } & & Wind & SSW & \multicolumn{6}{|c|}{ Average Wind Speeds (UA) (meters/sec) } \\
\hline Speed & & & \multicolumn{3}{|c|}{ Stability Category } & & & Speed & & & \multicolumn{3}{|c|}{ Stability Category } & & \\
\hline Categor & A & $\mathrm{B}$ & $\mathrm{C}$ & $D$ & $E$ & $F$ & G & Category & A & $B$ & C & D & $E$ & $\mathbf{F}$ & G \\
\hline 1 & 114 & 12 & 11 & 10 & 4 & 1 & 0 & \begin{tabular}{|l|} 
\\
\end{tabular} & 1.23 & 1.73 & 1.45 & 1.26 & 1.41 & 1.43 & 0.00 \\
\hline 2 & 294 & 127 & 139 & 88 & 43 & 3 & 2 & 2 & 2.73 & 2.95 & 2.99 & 3.02 & 3.00 & 3.31 & 3.32 \\
\hline 3 & 122 & 143 & 126 & 93 & 109 & 13 & 1 & 3 & 4.60 & 4.70 & 4.80 & 4.87 & 4.88 & 4.81 & 4.11 \\
\hline 4 & 16 & 31 & 31 & 16 & 15 & 4 & 0 & 4 & 6.48 & 6.52 & 6.35 & 6.52 & 6.33 & 6.17 & 0.00 \\
\hline 5 & 4 & 7 & 4 & 0 & 0 & 0 & 0 & 5 & 8.56 & 8.70 & 8.33 & 0.00 & 0.00 & 0.00 & 0.00 \\
\hline 6 & 0 & 0 & 0 & 0 & 0 & 0 & 0 & 6 & 0.00 & 0.00 & 0.00 & 0.00 & 0.00 & 0.00 & 0.00 \\
\hline
\end{tabular}


APPENDIX B. ORIGINAL TEST CASE DEMONSTRATION 


\section{APPENDIX B. ORIGINAL TEST CASE DEMONSTRATION}

Each of the VENTSAR Test cases were executed using VENTSAR XL to ensure that all Macros had been coded properly. Table B1 shows the input parameters used for each of the test cases.

Tables B2 and B3 show the results of the comparison for test case 1 for the first two release heights respectively. The results are shown in their entirety. Percentage differences between VENTSAR and VENTSAR XL are also shown. Table B4 shows the results of the remaining test cases for a selected number of user distances. All numbers were compared but only the selected distances are shown here. Doses were hand calculated to ensure they were correct. 


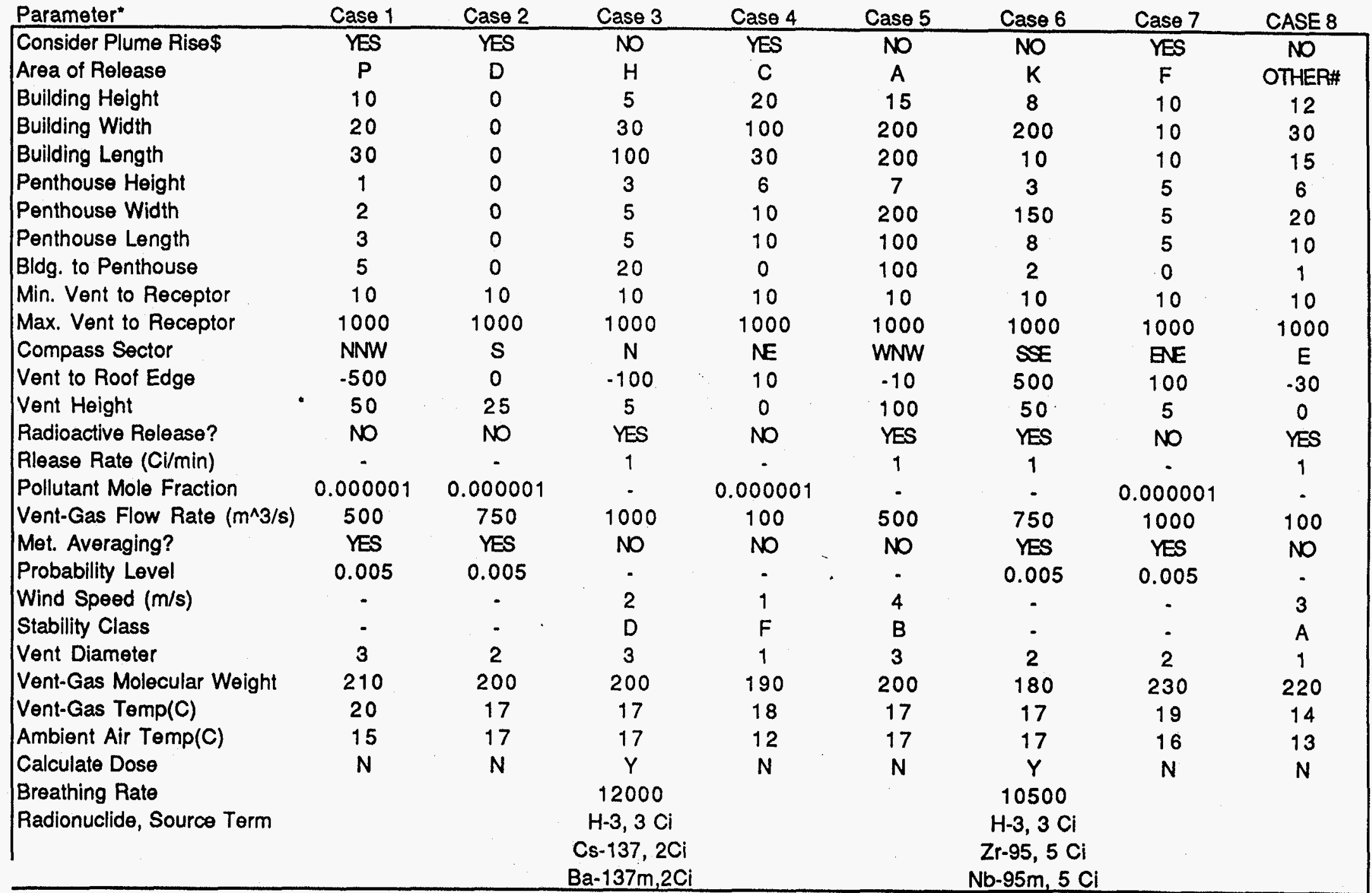

- unit are in meters unless otherwise stated

$\$$ plume rise only for chemical release (with pollutant mole fraction)

\# Release Coordinates at center of site: E58000; N 62000 
Table B2. Results for Test Case 1 (Release Height $=50 \mathrm{~m}$ )

\begin{tabular}{|c|c|c|c|c|c|c|}
\hline $\begin{array}{l}\text { Downwind } \\
\text { Distance }\end{array}$ & $\begin{array}{l}\text { VENTSAR } \\
99.50 \% \\
X / Q\end{array}$ & $\begin{array}{l}\text { VENTSAR } \\
\text { Annual } \\
\text { Average }\end{array}$ & $\begin{array}{c}\text { VENTSAR XL } \\
99.50 \% \\
X / Q\end{array}$ & $\begin{array}{c}\text { VENTSAR XL } \\
\text { Annual } \\
\text { Average }\end{array}$ & $\begin{array}{c}\% \text { Diff } \\
X / Q \\
\star \star\end{array}$ & $\begin{array}{c}\% \text { Diff } \\
\text { Ann Ave } \\
\star \star\end{array}$ \\
\hline 10.00 & $0.00 E+00$ & $0.00 E+00$ & $0.00 E+00$ & $0.00 E+00$ & $\star \star$ & $\star *$ \\
\hline 14.95 & $0.00 E+00$ & $0.00 E+00$ & $0.00 \mathrm{E}+00$ & $0.00 E+00$ & ** & $\star \star$ \\
\hline 19.90 & $0.00 E+00$ & $0.00 E+00$ & $0.00 E+00$ & $1.58 \mathrm{E}-202$ & * & $\star \star$ \\
\hline 24.85 & $0.00 E+00$ & $0.00 E+00$ & $0.00 E+00$ & $6.93 E-146$ & ** & ** \\
\hline 29.80 & $0.00 E+00$ & $0.00 E+00$ & $4.56 E-214$ & $1.80 \mathrm{E}-112$ & ** & ** \\
\hline 34.75 & $0.00 E+00$ & $0.00 \mathrm{E}+00$ & $5.39 E-169$ & $7.26 \mathrm{E}-91$ & ** & $\star *$ \\
\hline 39.70 & $0.00 E+00$ & $5.86 E-76$ & $4.16 \mathrm{E}-138$ & $5.83 E-76$ & $* \star$ & $0.53 \%$ \\
\hline 44.65 & $0.00 E+00$ & $3.58 \mathrm{E}-65$ & $7.01 E-116$ & $3.56 E-65$ & ** & $0.43 \%$ \\
\hline 49.60 & $0.00 E+00$ & $4.51 E-57$ & 2.86E-99 & 4.49E-57 & ** & $0.43 \%$ \\
\hline 54.55 & $0.00 E+00$ & $8.29 E-51$ & $1.77 E-86$ & $8.26 E-51$ & ** & $0.39 \%$ \\
\hline 59.50 & $0.00 E+00$ & 7.59E-46 & $1.27 E-105$ & $7.57 E-46$ & * & $0.27 \%$ \\
\hline 64.45 & $0.00 E+00$ & $7.76 E-42$ & $8.73 \mathrm{E}-95$ & $7.73 E-42$ & $\star \star$ & $0.32 \%$ \\
\hline 69.40 & $0.00 E+00$ & $1.53 E-38$ & $1.16 \mathrm{E}-85$ & $1.52 E-38$ & ** & $0.47 \%$ \\
\hline 74.35 & $0.00 E+00$ & $8.50 E-36$ & $5.26 \mathrm{E}-78$ & $8.47 E-36$ & $\star \star$ & $0.30 \%$ \\
\hline 79.30 & $1.59 \mathrm{E}-71$ & $1.76 \mathrm{E}-33$ & $1.58 \mathrm{E}-71$ & $1.76 \mathrm{E}-33$ & $0.46 \%$ & $0.18 \%$ \\
\hline 84.25 & $5.47 \mathrm{E}-66$ & $1.67 E-31$ & $5.44 E-66$ & $1.66 E-31$ & $0.59 \%$ & $0.49 \%$ \\
\hline 89.20 & $3.25 E-61$ & 8.37E-30 & 3.23E-61 & $8.35 E-30$ & $0.48 \%$ & $0.20 \%$ \\
\hline 94.15 & $4.61 E-57$ & $2.51 E-28$ & 4.59E-57 & $2.51 E-28$ & $0.43 \%$ & $0.14 \%$ \\
\hline 99.10 & 2.00E-53 & $4.92 E-27$ & $1.99 E-53$ & $4.91 E-27$ & $0.29 \%$ & $0.15 \%$ \\
\hline 104.05 & $1.51 E-49$ & $1.12 E-25$ & $1.51 E-49$ & $1.12 E-25$ & $0.02 \%$ & $0.04 \%$ \\
\hline 109.00 & $5.29 E-46$ & $2.05 E-24$ & $5.29 E-46$ & $2.05 E-24$ & $0.04 \%$ & $-0.18 \%$ \\
\hline 113.95 & $6.79 E-43$ & $2.62 E-23$ & $6.79 E-43$ & $2.62 E-23$ & $0.02 \%$ & $-0.10 \%$ \\
\hline 118.90 & $3.75 E-40$ & 2.47E-22 & $3.75 E-40$ & $2.47 \mathrm{E}-22$ & $0.07 \%$ & $-0.02 \%$ \\
\hline 123.85 & $1.01 \mathrm{E}-37$ & $1.80 \mathrm{E}-21$ & $1.01 E-37$ & $1.80 \mathrm{E}-21$ & $-0.19 \%$ & $0.09 \%$ \\
\hline 128.80 & $1.49 E-35$ & $1.05 E-20$ & $1.49 \mathrm{E}-35$ & $1.05 \mathrm{E}-20$ & $0.32 \%$ & $-0.11 \%$ \\
\hline 133.75 & $1.29 E-33$ & $5.09 E-20$ & $1.29 E-33$ & $5.09 E-20$ & $-0.12 \%$ & $0.02 \%$ \\
\hline 138.70 & $7.15 E-32$ & 2.09E-19 & $7.15 E-32$ & 2.09E-19 & $0.01 \%$ & $-0.21 \%$ \\
\hline 143.65 & 2.67E-30 & $7.49 E-19$ & $2.67 E-30$ & $7.49 E-19$ & $-0.12 \%$ & $0.05 \%$ \\
\hline 148.60 & $7.10 \mathrm{E}-29$ & $2.37 \mathrm{E}-18$ & 7.10E-29 & $2.37 E-18$ & $0.00 \%$ & $0.14 \%$ \\
\hline 153.55 & $1.40 E-27$ & $6.72 E-18$ & $1.40 \mathrm{E}-27$ & $6.72 \mathrm{E}-18$ & $0.21 \%$ & $0.00 \%$ \\
\hline 158.50 & $2.11 \mathrm{E}-26$ & $1.74 \mathrm{E}-17$ & $2.11 \mathrm{E}-26$ & $1.74 \mathrm{E}-17$ & $-0.05 \%$ & $0.24 \%$ \\
\hline 163.45 & $2.53 E-25$ & 4. $12 \mathrm{E}-17$ & $2.53 E-25$ & $4.12 \mathrm{E}-17$ & $0.15 \%$ & $-0.12 \%$ \\
\hline 168.40 & $2.46 E-24$ & $9.11 \mathrm{E}-17$ & $2.46 \mathrm{E}-24$ & $9.11 \mathrm{E}-17$ & $0.10 \%$ & $0.05 \%$ \\
\hline 173.35 & $1.99 E-23$ & $1.88 E-16$ & $1.99 \mathrm{E}-23$ & $1.88 E-16$ & $0.11 \%$ & $-0.13 \%$ \\
\hline 178.30 & $1.36 \mathrm{E}-22$ & $3.67 \mathrm{E}-16$ & $1.36 \mathrm{E}-22$ & $3.67 E-16$ & $-0.27 \%$ & $-0.04 \%$ \\
\hline 183.25 & $8.07 E-22$ & $6.80 E-16$ & $8.07 E-22$ & $6.80 \mathrm{E}-16$ & $0.00 \%$ & $0.04 \%$ \\
\hline 188.20 & $4.18 E-21$ & $1.20 E-15$ & 4.18E-21 & $1.20 \mathrm{E}-15$ & $-0.04 \%$ & $-0.13 \%$ \\
\hline 193.15 & $1.92 E-20$ & $2.04 \mathrm{E}-15$ & $1.92 \mathrm{E}-20$ & $2.04 \mathrm{E}-15$ & $-0.11 \%$ & $0.12 \%$ \\
\hline 198.10 & $7.93 \mathrm{E}-20$ & $3.33 E-15$ & $7.93 E-20$ & $3.33 \mathrm{E}-15$ & $0.04 \%$ & $0.02 \%$ \\
\hline 203.05 & $2.96 E-19$ & $5.26 E-15$ & $2.96 \mathrm{E}-19$ & $5.26 \mathrm{E}-15$ & $-0.12 \%$ & $-0.04 \%$ \\
\hline 208.00 & $1.01 E-18$ & $8.07 E-15$ & $1.01 E-18$ & 8.07E-15 & $-0.33 \%$ & $-0.04 \%$ \\
\hline 212.95 & $3.19 E-18$ & $1.21 E-14$ & $3.19 E-18$ & $1.21 \mathrm{E}-14$ & $-0.13 \%$ & $0.33 \%$ \\
\hline 217.90 & $9.35 \mathrm{E}-18$ & $1.76 E-14$ & $9.35 E-18$ & $1.76 \mathrm{E}-14$ & $0.02 \%$ & $0.06 \%$ \\
\hline 222.85 & $2.56 \mathrm{E}-17$ & $2.51 \mathrm{E}-14$ & $2.56 \mathrm{E}-17$ & $2.51 E-14$ & $0.15 \%$ & $-0.04 \%$ \\
\hline
\end{tabular}

** Value in VENTSAR printed as zero since below cutoff. 


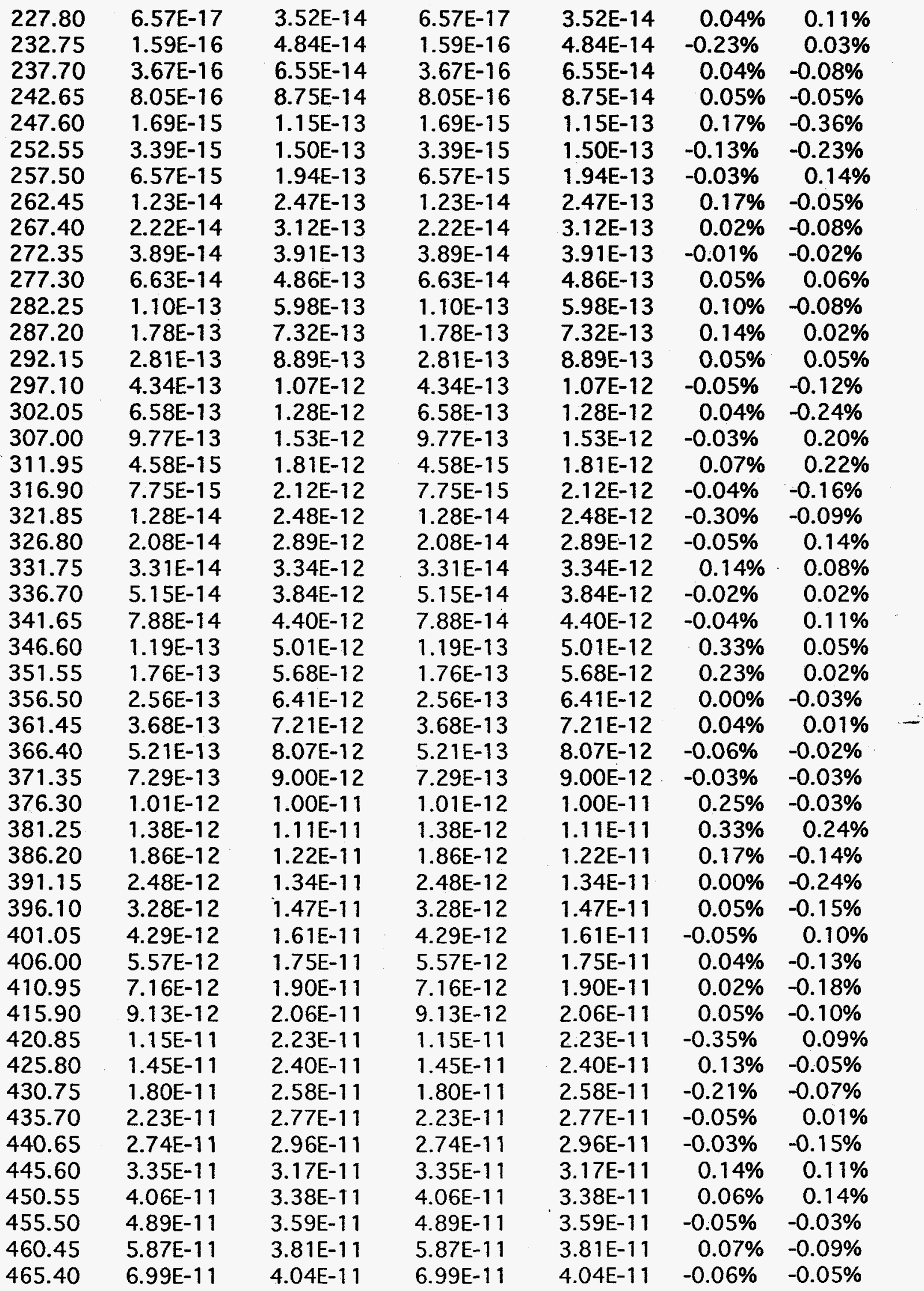




\begin{tabular}{|c|c|c|c|c|c|c|}
\hline 470.35 & $8.30 \mathrm{E}-11$ & $4.28 E-11$ & $8.30 \mathrm{E}-11$ & $4.28 E-11$ & $0.06 \%$ & $0.06 \%$ \\
\hline 475.30 & $9.79 \mathrm{E}-11$ & $4.52 \mathrm{E}-11$ & 9.79E-11 & $4.52 E-11$ & $0.01 \%$ & $0.02 \%$ \\
\hline 480.25 & $1.15 E-10$ & 4.77E-11 & $1.15 \mathrm{E}-10$ & 4.77E-11 & $0.04 \%$ & $0.06 \%$ \\
\hline 485.20 & $1.34 \mathrm{E}-10$ & $5.02 E-11$ & $1.34 \mathrm{E}-10$ & $5.02 E-11$ & $-0.27 \%$ & $-0.02 \%$ \\
\hline 490.15 & $1.56 E-10$ & $5.28 \mathrm{E}-11$ & $1.56 \mathrm{E}-10$ & $5.28 E-11$ & $-0.22 \%$ & $-0.02 \%$ \\
\hline 495.10 & $1.81 E-10$ & $5.55 E-11$ & $1.81 \mathrm{E}-10$ & $5.55 E-11$ & $-0.08 \%$ & $0.05 \%$ \\
\hline 500.05 & $2.84 E-10$ & $6.06 \mathrm{E}-11$ & $2.84 E-10$ & $6.06 \mathrm{E}-11$ & $0.08 \%$ & $-0.03 \%$ \\
\hline 505.00 & $3.42 E-10$ & $6.39 \mathrm{E}-11$ & $3.23 E-10$ & $6.34 \mathrm{E}-11$ & $5.61 \%$ & $0.74 \%$ \\
\hline 509.95 & $3.66 \mathrm{E}-10$ & $6.33 E-11$ & $3.66 \mathrm{E}-10$ & $6.33 \mathrm{E}-11$ & $-0.02 \%$ & $0.02 \%$ \\
\hline 514.90 & $4.14 E-10$ & $6.61 \mathrm{E}-11$ & 4. $14 \mathrm{E}-10$ & $6.61 \mathrm{E}-11$ & $0.04 \%$ & $-0.02 \%$ \\
\hline 519.85 & 4. $66 \mathrm{E}-10$ & $6.90 \mathrm{E}-11$ & $4.66 \mathrm{E}-10$ & $6.90 \mathrm{E}-11$ & $-0.06 \%$ & $0.02 \%$ \\
\hline 524.80 & $5.24 E-10$ & $7.19 \mathrm{E}-11$ & $5.24 \mathrm{E}-10$ & 7.19E-11 & $0.06 \%$ & $-0.02 \%$ \\
\hline 529.75 & $5.86 E-10$ & $7.49 \mathrm{E}-11$ & $5.86 \mathrm{E}-10$ & $7.49 E-11$ & $-0.08 \%$ & $0.01 \%$ \\
\hline 534.70 & $5.12 \mathrm{E}-10$ & $7.87 \mathrm{E}-11$ & $5.12 \mathrm{E}-10$ & 7.87E-11 & $-0.07 \%$ & $-0.05 \%$ \\
\hline 539.65 & $5.75 E-10$ & $8.19 E-11$ & $5.75 E-10$ & $8.19 E-11$ & $0.06 \%$ & $0.02 \%$ \\
\hline 544.60 & $6.43 E-10$ & 8.51E-11 & $6.43 \mathrm{E}-10$ & $8.51 \mathrm{E}-11$ & $0.07 \%$ & $0.02 \%$ \\
\hline 549.55 & $7.16 \mathrm{E}-10$ & $8.83 E-11$ & $7.16 \mathrm{E}-10$ & $8.83 E-11$ & $-0.06 \%$ & $-0.04 \%$ \\
\hline 554.50 & $7.96 \mathrm{E}-10$ & $8.78 E-11$ & $7.96 \mathrm{E}-10$ & $8.78 \mathrm{E}-11$ & $-0.06 \%$ & $0.02 \%$ \\
\hline 559.45 & $8.83 E-10$ & $9.10 E-11$ & 8.83E-10 & $9.10 \mathrm{E}-11$ & $-0.02 \%$ & $-0.04 \%$ \\
\hline 564.40 & $9.77 \mathrm{E}-10$ & $9.43 E-11$ & $9.77 \mathrm{E}-10$ & $9.43 E-11$ & $0.03 \%$ & $-0.03 \%$ \\
\hline 569.35 & $1.08 E-09$ & $9.77 \mathrm{E}-11$ & $1.08 \mathrm{E}-09$ & $9.77 \mathrm{E}-11$ & $0.24 \%$ & $0.03 \%$ \\
\hline 574.30 & $1.19 E-09$ & $1.01 \mathrm{E}-10$ & 1.19E-09 & $1.01 \mathrm{E}-10$ & $0.36 \%$ & $-0.07 \%$ \\
\hline 579.25 & 1.30E-09 & $1.05 E-10$ & 1.30E-09 & $1.05 E-10$ & $-0.13 \%$ & $0.46 \%$ \\
\hline 584.20 & $1.43 E-09$ & $1.08 \mathrm{E}-10$ & $1.43 E-09$ & $1.08 \mathrm{E}-10$ & $0.30 \%$ & $-0.01 \%$ \\
\hline 589.15 & $1.56 \mathrm{E}-09$ & $1.12 \mathrm{E}-10$ & $1.56 \mathrm{E}-09$ & $1.12 E-10$ & $0.12 \%$ & $0.40 \%$ \\
\hline 594.10 & 1.70E-09 & $1.15 \mathrm{E}-10$ & 1.70E-09 & $1.15 \mathrm{E}-10$ & $0.04 \%$ & $-0.13 \%$ \\
\hline 599.05 & $1.85 E-09$ & $1.19 \mathrm{E}-10$ & $1.85 E-09$ & $1.19 \mathrm{E}-10$ & $0.04 \%$ & $0.17 \%$ \\
\hline 604.00 & 2.01E-09 & $1.22 \mathrm{E}-10$ & 2.01E-09 & $1.22 E-10$ & $0.07 \%$ & $-0.41 \%$ \\
\hline 608.95 & 2.18E-09 & $1.26 \mathrm{E}-10$ & 2.18E-09 & $1.26 \mathrm{E}-10$ & $0.13 \%$ & $-0.19 \%$ \\
\hline 613.90 & 2.36E-09 & $1.30 \mathrm{E}-10$ & 2.36E-09 & $1.30 E-10$ & $0.19 \%$ & $-0.03 \%$ \\
\hline 618.85 & $2.54 E-09$ & $1.34 E-10$ & 2.54E-09 & $1.34 \mathrm{E}-10$ & $-0.15 \%$ & $0.08 \%$ \\
\hline 623.80 & $2.74 \mathrm{E}-09$ & $1.38 \mathrm{E}-10$ & $2.74 \mathrm{E}-09$ & $1.38 \mathrm{E}-10$ & $-0.08 \%$ & $0.15 \%$ \\
\hline 628.75 & 2.95E-09 & $1.42 \mathrm{E}-10$ & 2.95E-09 & $1.42 \mathrm{E}-10$ & $-0.03 \%$ & $0.18 \%$ \\
\hline 633.70 & 3.17E-09 & $1.46 \mathrm{E}-10$ & $3.17 \mathrm{E}-09$ & $1.46 \mathrm{E}-10$ & $-0.01 \%$ & $0.17 \%$ \\
\hline 638.65 & 3.40E-09 & $1.50 \mathrm{E}-10$ & $3.40 E-09$ & $1.50 \mathrm{E}-10$ & $-0.01 \%$ & $0.13 \%$ \\
\hline 643.60 & $3.64 E-09$ & $1.54 \mathrm{E}-10$ & $3.64 \mathrm{E}-09$ & $1.54 \mathrm{E}-10$ & $-0.04 \%$ & $0.06 \%$ \\
\hline 648.55 & $3.89 E-09$ & $1.58 \mathrm{E}-10$ & 3.89E-09 & 1. $58 \mathrm{E}-10$ & $-0.09 \%$ & $-0.04 \%$ \\
\hline 653.50 & $4.16 \mathrm{E}-09$ & $1.62 \mathrm{E}-10$ & 4. $16 \mathrm{E}-09$ & $1.62 E-10$ & $0.07 \%$ & $-0.17 \%$ \\
\hline 658.45 & 4.43E-09 & $1.67 E-10$ & $4.43 E-09$ & $1.67 E-10$ & $-0.04 \%$ & $0.27 \%$ \\
\hline 663.40 & 4.72E-09 & $1.71 E-10$ & 4.72E-09 & $1.71 \mathrm{E}-10$ & $0.04 \%$ & $0.08 \%$ \\
\hline 668.35 & $5.02 E-09$ & $1.75 E-10$ & $5.02 E-09$ & $1.75 E-10$ & $0.08 \%$ & $-0.13 \%$ \\
\hline 673.30 & 5.33E-09 & $1.80 E-10$ & $5.33 E-09$ & $1.80 E-10$ & $0.08 \%$ & $0.20 \%$ \\
\hline 678.25 & 5.65E-09 & $1.84 \mathrm{E}-10$ & 5.65E-09 & $1.84 \mathrm{E}-10$ & $0.05 \%$ & $-0.07 \%$ \\
\hline 683.20 & $5.98 \mathrm{E}-09$ & $1.89 E-10$ & $5.98 E-09$ & $1.89 E-10$ & $-0.01 \%$ & $0.19 \%$ \\
\hline 688.15 & 6.33E-09 & $1.93 E-10$ & 6.33E-09 & $1.93 E-10$ & $0.06 \%$ & $-0.12 \%$ \\
\hline 693.10 & $6.68 \mathrm{E}-09$ & $1.98 \mathrm{E}-10$ & 6.68E-09 & $1.98 E-10$ & $-0.05 \%$ & $0.07 \%$ \\
\hline 698.05 & 7.05E-09 & $2.03 E-10$ & 7.05E-09 & $2.03 E-10$ & $-0.04 \%$ & $0.23 \%$ \\
\hline 703.00 & $7.43 \mathrm{E}-09$ & $2.07 E-10$ & 7.43E-09 & $2.07 E-10$ & $-0.05 \%$ & $-0.13 \%$ \\
\hline 707.95 & 7.83E-09 & $2.12 \mathrm{E}-10$ & $7.83 E-09$ & $2.12 E-10$ & $0.03 \%$ & $-0.03 \%$ \\
\hline
\end{tabular}




\begin{tabular}{|c|c|c|c|c|c|c|}
\hline 712.90 & 8.39E-09 & $2.19 E-10$ & 8.39E-09 & $2.19 \mathrm{E}-10$ & $0.05 \%$ & $-0.07 \%$ \\
\hline 717.85 & 9.01E-09 & 2.27E-10 & 9.01E-09 & $2.27 \mathrm{E}-10$ & $0.00 \%$ & $0.00 \%$ \\
\hline 722.80 & 9.67E-09 & 2.35E-10 & 9.67E-09 & $2.35 \mathrm{E}-10$ & $0.05 \%$ & $-0.01 \%$ \\
\hline 727.75 & $1.04 E-08$ & $2.43 E-10$ & $1.04 \mathrm{E}-08$ & $2.43 \mathrm{E}-10$ & $0.46 \%$ & $-0.11 \%$ \\
\hline 732.70 & $1.11 \mathrm{E}-08$ & $2.52 E-10$ & $1.11 \mathrm{E}-08$ & $2.52 E-10$ & $0.26 \%$ & $0.12 \%$ \\
\hline 737.65 & $1.18 \mathrm{E}-08$ & 2.60E-10 & $1.18 \mathrm{E}-08$ & $2.60 \mathrm{E}-10$ & $-0.18 \%$ & $-0.13 \%$ \\
\hline 742.60 & $1.26 \mathrm{E}-08$ & $2.69 E-10$ & $1.26 \mathrm{E}-08$ & $2.69 \mathrm{E}-10$ & $-0.04 \%$ & $-0.07 \%$ \\
\hline 747.55 & $1.34 E-08$ & $2.78 E-10$ & $1.34 E-08$ & $2.78 \mathrm{E}-10$ & $-0.16 \%$ & $-0.08 \%$ \\
\hline 752.50 & $1.43 E-08$ & 2.87E-10 & $1.43 E-08$ & $2.87 E-10$ & $0.21 \%$ & $-0.17 \%$ \\
\hline 757.45 & $1.52 \mathrm{E}-08$ & $2.97 \mathrm{E}-10$ & $1.52 \mathrm{E}-08$ & $2.97 \mathrm{E}-10$ & $0.30 \%$ & $0.02 \%$ \\
\hline 762.40 & 1.61E-08 & $3.07 E-10$ & $1.61 \mathrm{E}-08$ & $3.07 E-10$ & $0.18 \%$ & $0.12 \%$ \\
\hline 767.35 & $1.70 \mathrm{E}-08$ & $3.16 \mathrm{E}-10$ & $1.70 \mathrm{E}-08$ & $3.16 \mathrm{E}-10$ & $-0.13 \%$ & $-0.16 \%$ \\
\hline 772.30 & $1.80 \mathrm{E}-08$ & $3.27 E-10$ & $1.80 \mathrm{E}-08$ & $3.27 E-10$ & $-0.03 \%$ & $0.13 \%$ \\
\hline 777.25 & $1.90 E-08$ & $3.37 E-10$ & $1.90 \mathrm{E}-08$ & $3.37 E-10$ & $-0.13 \%$ & $0.03 \%$ \\
\hline 782.20 & 2.01E-08 & $3.47 E-10$ & 2.01E-08 & $3.47 E-10$ & $0.11 \%$ & $-0.12 \%$ \\
\hline 787.15 & $2.12 \mathrm{E}-08$ & $3.58 E-10$ & 2.12E-08 & $3.58 E-10$ & $0.16 \%$ & $-0.04 \%$ \\
\hline 792.10 & $2.23 E-08$ & $3.69 \mathrm{E}-10$ & $2.23 \mathrm{E}-08$ & $3.69 E-10$ & $0.06 \%$ & $-0.02 \%$ \\
\hline 797.05 & $2.34 \mathrm{E}-08$ & $3.80 E-10$ & 2.34E-08 & $3.80 E-10$ & $-0.18 \%$ & $-0.06 \%$ \\
\hline 802.00 & 2.46E-08 & $3.92 \mathrm{E}-10$ & $2.46 \mathrm{E}-08$ & $3.92 \mathrm{E}-10$ & $-0.13 \%$ & $0.11 \%$ \\
\hline 806.95 & $2.59 \mathrm{E}-08$ & $4.03 E-10$ & 2.59E-08 & $4.03 E-10$ & $0.17 \%$ & $-0.03 \%$ \\
\hline 811.90 & $2.71 E-08$ & $4.15 E-10$ & $2.71 E-08$ & $4.15 \mathrm{E}-10$ & $-0.04 \%$ & $0.03 \%$ \\
\hline 816.85 & 2.84E-08 & 4.27E-10 & $2.84 \mathrm{E}-08$ & $4.27 E-10$ & $-0.01 \%$ & $0.03 \%$ \\
\hline 821.80 & 2.97E-08 & 4.39E-10 & 2.97E-08 & $4.39 E-10$ & $-0.08 \%$ & $0.00 \%$ \\
\hline 826.75 & $3.11 \mathrm{E}-08$ & $4.51 \mathrm{E}-10$ & $3.11 \mathrm{E}-08$ & $4.51 E-10$ & $0.06 \%$ & $-0.09 \%$ \\
\hline 831.70 & $3.25 E-08$ & $4.64 \mathrm{E}-10$ & $3.25 E-08$ & $4.64 E-10$ & $0.10 \%$ & $0.01 \%$ \\
\hline 836.65 & 3.39E-08 & 4.77E-10 & $3.39 E-08$ & 4.77E-10 & $0.04 \%$ & $0.06 \%$ \\
\hline 841.60 & 3.53E-08 & $4.90 \mathrm{E}-10$ & $3.53 E-08$ & $4.90 E-10$ & $-0.11 \%$ & $0.06 \%$ \\
\hline 846.55 & $3.68 \mathrm{E}-08$ & $5.03 E-10$ & $3.68 \mathrm{E}-08$ & $5.03 E-10$ & $-0.06 \%$ & $0.03 \%$ \\
\hline 851.50 & $3.83 E-08$ & $5.16 \mathrm{E}-10$ & $3.83 E-08$ & $5.16 \mathrm{E}-10$ & $-0.09 \%$ & $-0.03 \%$ \\
\hline 856.45 & $3.99 E-08$ & $5.30 \mathrm{E}-10$ & $3.99 E-08$ & $5.30 \mathrm{E}-10$ & $0.06 \%$ & $0.06 \%$ \\
\hline 861.40 & 4.14E-08 & $5.43 E-10$ & $4.15 \mathrm{E}-08$ & $5.43 E-10$ & $-0.12 \%$ & $-0.07 \%$ \\
\hline 866.35 & 4.31E-08 & $5.57 \mathrm{E}-10$ & 4.31E-08 & $5.57 E-10$ & $0.11 \%$ & $-0.05 \%$ \\
\hline 871.30 & 4.47E-08 & $5.71 E-10$ & $4.47 E-08$ & $5.71 E-10$ & $0.04 \%$ & $-0.06 \%$ \\
\hline 876.25 & 4.63E-08 & $5.86 \mathrm{E}-10$ & 4.63E-08 & $5.86 \mathrm{E}-10$ & $-0.08 \%$ & $0.07 \%$ \\
\hline 881.20 & 4.80E-08 & $6.00 E-10$ & $4.80 \mathrm{E}-08$ & $6.00 \mathrm{E}-10$ & $-0.05 \%$ & $0.00 \%$ \\
\hline 886.15 & 4.97E-08 & $6.15 E-10$ & 4.97E-08 & $6.15 \mathrm{E}-10$ & $-0.07 \%$ & $0.07 \%$ \\
\hline 891.10 & $5.15 \mathrm{E}-08$ & $6.29 E-10$ & $5.15 \mathrm{E}-08$ & $6.29 \mathrm{E}-10$ & $0.05 \%$ & $-0.04 \%$ \\
\hline 896.05 & $5.32 E-08$ & $6.44 \mathrm{E}-10$ & $5.32 \mathrm{E}-08$ & $6.44 \mathrm{E}-10$ & $-0.07 \%$ & $-0.02 \%$ \\
\hline 901.00 & 5.50E-08 & $6.59 E-10$ & $5.50 \mathrm{E}-08$ & $6.59 E-10$ & $-0.04 \%$ & $-0.03 \%$ \\
\hline 905.95 & $5.68 \mathrm{E}-08$ & $6.74 E-10$ & 5.68E-08 & $6.74 \mathrm{E}-10$ & $-0.06 \%$ & $-0.05 \%$ \\
\hline 910.90 & $5.87 E-08$ & $6.90 \mathrm{E}-10$ & $5.87 E-08$ & $6.90 E-10$ & $0.06 \%$ & $0.04 \%$ \\
\hline 915.85 & $6.05 \mathrm{E}-08$ & $7.05 E-10$ & $6.05 E-08$ & 7.05E-10 & $-0.04 \%$ & $-0.02 \%$ \\
\hline 920.80 & $6.24 \mathrm{E}-08$ & $7.21 E-10$ & $6.24 \mathrm{E}-08$ & $7.21 E-10$ & $0.00 \%$ & $0.03 \%$ \\
\hline 925.75 & $6.43 \mathrm{E}-08$ & $7.36 \mathrm{E}-10$ & $6.43 E-08$ & 7.37E-10 & $0.00 \%$ & $-0.07 \%$ \\
\hline 930.70 & $6.62 \mathrm{E}-08$ & $7.52 E-10$ & $6.62 \mathrm{E}-08$ & $7.52 E-10$ & $-0.03 \%$ & $-0.05 \%$ \\
\hline 935.65 & 6.82E-08 & $7.68 \mathrm{E}-10$ & $6.82 \mathrm{E}-08$ & $7.68 \mathrm{E}-10$ & $0.06 \%$ & $-0.05 \%$ \\
\hline 940.60 & 7.01E-08 & $7.84 E-10$ & 7.01E-08 & $7.84 \mathrm{E}-10$ & $-0.02 \%$ & $-0.06 \%$ \\
\hline 945.55 & $7.21 \mathrm{E}-08$ & $8.01 E-10$ & 7.21E-08 & $8.01 E-10$ & $0.02 \%$ & $0.04 \%$ \\
\hline 950.50 & $7.41 \mathrm{E}-08$ & $8.17 \mathrm{E}-10$ & $7.41 \mathrm{E}-08$ & $8.17 E-10$ & $0.03 \%$ & $0.00 \%$ \\
\hline
\end{tabular}




$\begin{array}{rrrrrrr}955.45 & 7.61 \mathrm{E}-08 & 8.33 \mathrm{E}-10 & 7.61 \mathrm{E}-08 & 8.33 \mathrm{E}-10 & 0.02 \% & -0.06 \% \\ 960.40 & 7.81 \mathrm{E}-08 & 8.50 \mathrm{E}-10 & 7.81 \mathrm{E}-08 & 8.50 \mathrm{E}-10 & -0.01 \% & 0.00 \% \\ 965.35 & 8.01 \mathrm{E}-08 & 8.67 \mathrm{E}-10 & 8.01 \mathrm{E}-08 & 8.67 \mathrm{E}-10 & -0.06 \% & 0.04 \% \\ 970.30 & 8.22 \mathrm{E}-08 & 8.83 \mathrm{E}-10 & 8.22 \mathrm{E}-08 & 8.83 \mathrm{E}-10 & 0.01 \% & -0.04 \% \\ 975.25 & 8.43 \mathrm{E}-08 & 9.00 \mathrm{E}-10 & 8.43 \mathrm{E}-08 & 9.00 \mathrm{E}-10 & 0.05 \% & -0.02 \% \\ 980.20 & 8.63 \mathrm{E}-08 & 9.17 \mathrm{E}-10 & 8.63 \mathrm{E}-08 & 9.17 \mathrm{E}-10 & -0.04 \% & -0.01 \% \\ 985.15 & 8.84 \mathrm{E}-08 & 9.34 \mathrm{E}-10 & 8.84 \mathrm{E}-08 & 9.34 \mathrm{E}-10 & -0.03 \% & -0.01 \% \\ 990.10 & 9.05 \mathrm{E}-08 & 9.51 \mathrm{E}-10 & 9.05 \mathrm{E}-08 & 9.51 \mathrm{E}-10 & -0.03 \% & -0.02 \% \\ 995.05 & 9.26 \mathrm{E}-08 & 9.68 \mathrm{E}-10 & 9.26 \mathrm{E}-08 & 9.68 \mathrm{E}-10 & -0.03 \% & -0.03 \%\end{array}$


Table B3. Results for Test Case 1 (Release Height $=55 \mathrm{~m}$ )

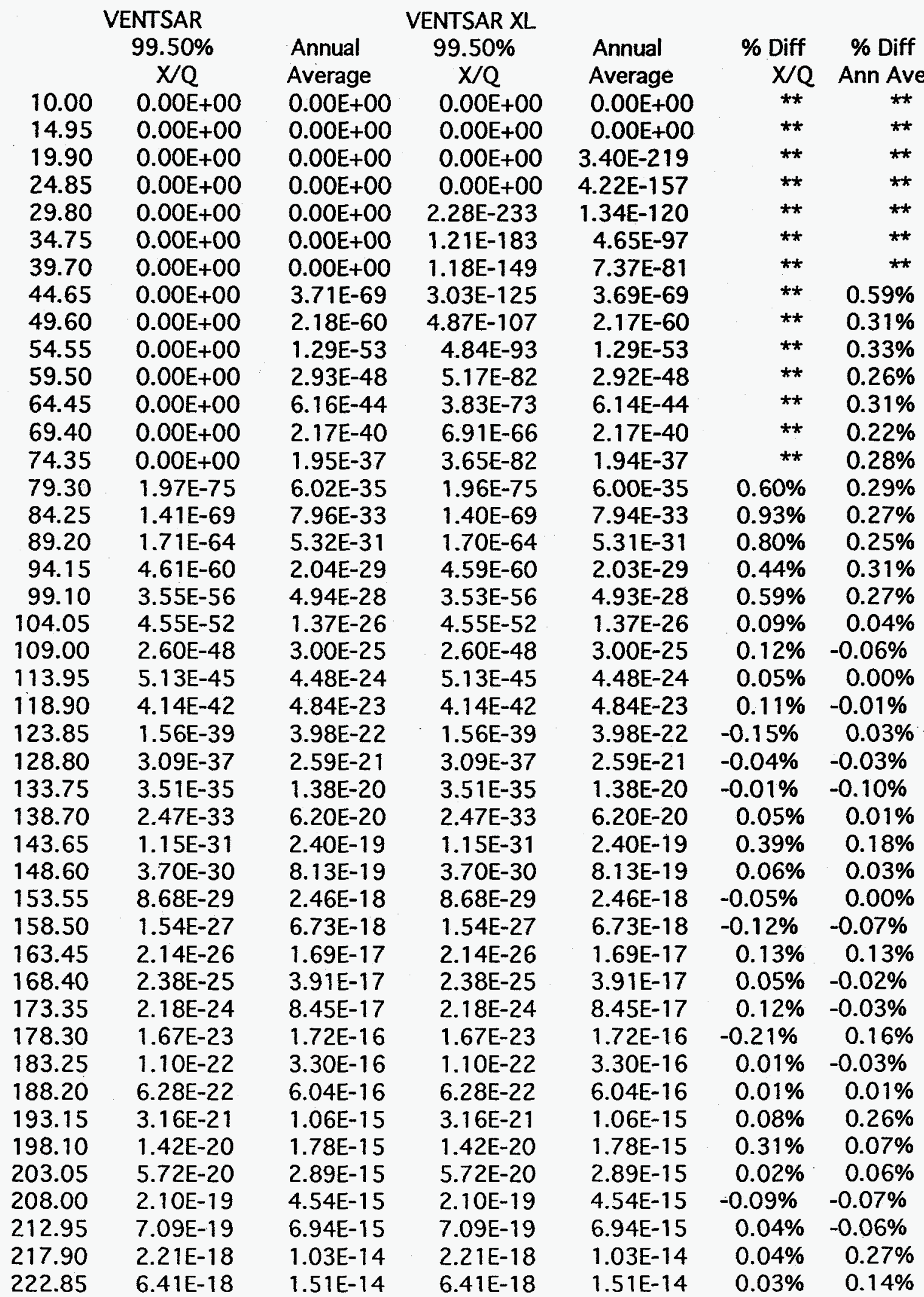

** Value in VENTSAR printed as zero since below cutoff. 


\begin{tabular}{|c|c|c|c|c|c|c|}
\hline 227.80 & $1.74 \mathrm{E}-17$ & $2.15 \mathrm{E}-14$ & $1.74 \mathrm{E}-17$ & $2.15 E-14$ & $0.00 \%$ & $-0.14 \%$ \\
\hline 232.75 & 4.45E-17 & $3.00 E-14$ & $4.45 E-17$ & $3.00 E-14$ & $0.06 \%$ & $-0.08 \%$ \\
\hline 237.70 & $1.08 \mathrm{E}-16$ & $4.13 E-14$ & $1.08 \mathrm{E}-16$ & 4.13E-14 & $0.45 \%$ & $0.00 \%$ \\
\hline 242.65 & 2.47E-16 & $5.60 E-14$ & $2.47 E-16$ & $5.60 E-14$ & $0.05 \%$ & $-0.03 \%$ \\
\hline 247.60 & $5.41 E-16$ & $7.48 E-14$ & $5.41 E-16$ & $7.48 E-14$ & $0.07 \%$ & $0.00 \%$ \\
\hline 252.55 & $1.13 \mathrm{E}-15$ & $9.87 E-14$ & $1.13 \mathrm{E}-15$ & $9.87 E-14$ & $-0.27 \%$ & $0.25 \%$ \\
\hline 257.50 & $2.28 E-15$ & $1.29 E-13$ & $2.28 E-15$ & $1.29 \mathrm{E}-13$ & $-0.01 \%$ & $0.03 \%$ \\
\hline 262.45 & $4.42 E-15$ & $1.66 \mathrm{E}-13$ & 4.42E-15 & $1.66 \mathrm{E}-13$ & $0.02 \%$ & $0.05 \%$ \\
\hline 267.40 & 8.27E-15 & $2.12 E-13$ & 8.27E-15 & $2.12 \mathrm{E}-13$ & $0.00 \%$ & $-0.01 \%$ \\
\hline 272.35 & $1.50 E-14$ & $2.68 E-13$ & $1.50 E-14$ & $2.68 \mathrm{E}-13$ & $0.13 \%$ & $-0.01 \%$ \\
\hline 277.30 & $2.63 \mathrm{E}-14$ & $3.36 E-13$ & 2.63E-14 & $3.36 \mathrm{E}-13$ & $-0.09 \%$ & $-0.01 \%$ \\
\hline 282.25 & $4.50 E-14$ & $4.18 \mathrm{E}-13$ & $4.50 E-14$ & $4.18 \mathrm{E}-13$ & $0.08 \%$ & $0.05 \%$ \\
\hline 287.20 & $7.48 \mathrm{E}-14$ & $5.15 E-13$ & $7.48 \mathrm{E}-14$ & $5.15 E-13$ & $-0.01 \%$ & $-0.06 \%$ \\
\hline 292.15 & $1.21 \mathrm{E}-13$ & $6.31 \mathrm{E}-13$ & $1.21 \mathrm{E}-13$ & $6.31 \mathrm{E}-13$ & $-0.35 \%$ & $0.02 \%$ \\
\hline 297.10 & $1.93 E-13$ & $7.67 \mathrm{E}-13$ & $1.93 E-13$ & $7.67 E-13$ & $0.22 \%$ & $0.04 \%$ \\
\hline 302.05 & $2.99 E-13$ & $9.25 \mathrm{E}-13$ & $2.99 E-13$ & $9.25 E-13$ & $0.04 \%$ & $-0.05 \%$ \\
\hline 307.00 & $4.55 E-13$ & $1.11 E-12$ & $4.55 E-13$ & $1.11 \mathrm{E}-12$ & $0.10 \%$ & $0.04 \%$ \\
\hline 311.95 & $6.78 E-13$ & $1.32 \mathrm{E}-12$ & $6.78 E-13$ & $1.32 E-12$ & $-0.03 \%$ & $-0.14 \%$ \\
\hline 316.90 & $9.94 \mathrm{E}-13$ & $1.57 E-12$ & $9.94 E-13$ & $1.57 E-12$ & $0.01 \%$ & $0.31 \%$ \\
\hline 321.85 & $1.43 \mathrm{E}-12$ & $1.84 \mathrm{E}-12$ & $1.43 E-12$ & $1.84 \mathrm{E}-12$ & $-0.16 \%$ & $-0.12 \%$ \\
\hline 326.80 & $2.03 E-12$ & $2.16 \mathrm{E}-12$ & $2.03 \mathrm{E}-12$ & $2.16 \mathrm{E}-12$ & $-0.08 \%$ & $0.19 \%$ \\
\hline 331.75 & $2.84 \mathrm{E}-12$ & $2.51 \mathrm{E}-12$ & $2.84 E-12$ & $2.51 \mathrm{E}-12$ & $0.05 \%$ & $0.04 \%$ \\
\hline 336.70 & $3.91 \mathrm{E}-12$ & $2.90 \mathrm{E}-12$ & $3.91 E-12$ & $2.90 \mathrm{E}-12$ & $-0.02 \%$ & $-0.16 \%$ \\
\hline 341.65 & $5.32 E-12$ & $3.35 E-12$ & $5.32 \mathrm{E}-12$ & $3.35 \mathrm{E}-12$ & $0.06 \%$ & $0.14 \%$ \\
\hline 346.60 & $7.14 \mathrm{E}-12$ & $3.83 E-12$ & $7.14 \mathrm{E}-12$ & $3.83 \mathrm{E}-12$ & $0.03 \%$ & $-0.10 \%$ \\
\hline 351.55 & $9.47 \mathrm{E}-12$ & $4.37 E-12$ & $9.47 E-12$ & 4.37E-12 & $0.01 \%$ & $-0.07 \%$ \\
\hline 356.50 & $1.24 \mathrm{E}-11$ & $4.96 \mathrm{E}-12$ & $1.24 E-11$ & $4.96 \mathrm{E}-12$ & $-0.17 \%$ & $-0.10 \%$ \\
\hline 361.45 & $1.61 \mathrm{E}-11$ & $5.61 \mathrm{E}-12$ & $1.61 E-11$ & $5.61 \mathrm{E}-12$ & $-0.12 \%$ & $-0.04 \%$ \\
\hline 366.40 & 2.07E-11 & $6.32 \mathrm{E}-12$ & $2.07 \mathrm{E}-11$ & $6.32 \mathrm{E}-12$ & $-0.05 \%$ & $0.05 \%$ \\
\hline 371.35 & $2.64 \mathrm{E}-11$ & $7.08 \mathrm{E}-12$ & $2.64 \mathrm{E}-11$ & $7.08 \mathrm{E}-12$ & $0.17 \%$ & $-0.01 \%$ \\
\hline 376.30 & $3.32 E-11$ & $7.91 \mathrm{E}-12$ & $3.32 E-11$ & $7.91 \mathrm{E}-12$ & $-0.10 \%$ & $0.04 \%$ \\
\hline 381.25 & $4.15 E-11$ & $8.79 \mathrm{E}-12$ & $4.15 \mathrm{E}-11$ & $8.79 E-12$ & $-0.12 \%$ & $-0.06 \%$ \\
\hline 386.20 & $5.15 E-11$ & $9.75 \mathrm{E}-12$ & $5.15 E-11$ & $9.75 E-12$ & $-0.04 \%$ & $0.02 \%$ \\
\hline 391.15 & $6.34 \mathrm{E}-11$ & $1.08 \mathrm{E}-11$ & $6.34 \mathrm{E}-11$ & $1.08 \mathrm{E}-11$ & $0.03 \%$ & $0.31 \%$ \\
\hline 396.10 & $7.74 \mathrm{E}-11$ & $1.19 \mathrm{E}-11$ & $7.74 \mathrm{E}-11$ & $1.19 \mathrm{E}-11$ & $-0.01 \%$ & $0.41 \%$ \\
\hline 401.05 & $9.39 E-11$ & $1.30 \mathrm{E}-11$ & 9.39E-11 & 1.30E-11 & $0.04 \%$ & $-0.03 \%$ \\
\hline 406.00 & $1.13 E-10$ & $1.42 \mathrm{E}-11$ & $1.13 \mathrm{E}-10$ & $1.42 \mathrm{E}-11$ & $-0.05 \%$ & $-0.17 \%$ \\
\hline 410.95 & $1.35 E-10$ & $1.55 \mathrm{E}-11$ & $1.35 E-10$ & $1.55 E-11$ & $-0.22 \%$ & $-0.08 \%$ \\
\hline 415.90 & $1.61 \mathrm{E}-10$ & $1.69 \mathrm{E}-11$ & $1.61 \mathrm{E}-10$ & $1.69 \mathrm{E}-11$ & $0.04 \%$ & $0.18 \%$ \\
\hline 420.85 & $1.90 E-10$ & $1.83 \mathrm{E}-11$ & $1.90 E-10$ & $1.83 E-11$ & $-0.17 \%$ & $0.02 \%$ \\
\hline 425.80 & $2.24 \mathrm{E}-10$ & $1.98 \mathrm{E}-11$ & $2.24 \mathrm{E}-10$ & $1.98 \mathrm{E}-11$ & $0.09 \%$ & $0.04 \%$ \\
\hline 430.75 & $2.62 E-10$ & $2.14 \mathrm{E}-11$ & $2.62 E-10$ & $2.14 \mathrm{E}-11$ & $0.08 \%$ & $0.21 \%$ \\
\hline 435.70 & $3.05 E-10$ & $2.30 \mathrm{E}-11$ & $3.05 E-10$ & $2.30 \mathrm{E}-11$ & $0.11 \%$ & $0.06 \%$ \\
\hline 440.65 & $3.53 \mathrm{E}-10$ & $2.47 \mathrm{E}-11$ & $3.53 \mathrm{E}-10$ & $2.47 \mathrm{E}-11$ & $0.04 \%$ & $0.05 \%$ \\
\hline 445.60 & $4.07 \mathrm{E}-10$ & $2.65 \mathrm{E}-11$ & $4.07 E-10$ & $2.65 \mathrm{E}-11$ & $0.06 \%$ & $0.18 \%$ \\
\hline 450.55 & $4.67 E-10$ & $2.83 \mathrm{E}-11$ & $4.67 E-10$ & $2.83 \mathrm{E}-11$ & $0.04 \%$ & $0.05 \%$ \\
\hline 455.50 & $5.33 E-10$ & $3.02 \mathrm{E}-11$ & $5.33 E-10$ & $3.02 E-11$ & $-0.08 \%$ & $0.06 \%$ \\
\hline 460.45 & $6.07 \mathrm{E}-10$ & $3.21 \mathrm{E}-11$ & $6.07 E-10$ & $3.21 \mathrm{E}-11$ & $-0.01 \%$ & $-0.14 \%$ \\
\hline 465.40 & $6.88 \mathrm{E}-10$ & $3.42 \mathrm{E}-11$ & $6.88 \mathrm{E}-10$ & $3.42 \mathrm{E}-11$ & $-0.03 \%$ & $0.08 \%$ \\
\hline
\end{tabular}




\begin{tabular}{|c|c|c|c|c|c|c|}
\hline 470.35 & 7.77E-10 & $3.63 E-11$ & 7.77E-10 & $3.63 \mathrm{E}-11$ & $-0.02 \%$ & \\
\hline 475.30 & $8.75 E-10$ & $3.84 E-11$ & $8.75 E-10$ & $3.84 \mathrm{E}-11$ & $0.05 \%$ & $-0.03 \%$ \\
\hline 480.25 & $9.81 \mathrm{E}-10$ & 4.06E-11 & $9.81 E-10$ & $4.06 \mathrm{E}-11$ & $0.03 \%$ & $-0.06 \%$ \\
\hline 485.20 & $1.10 \mathrm{E}-09$ & 4.29E-11 & $1.10 \mathrm{E}-09$ & $4.29 E-11$ & $0.35 \%$ & $0.01 \%$ \\
\hline 490.15 & $1.22 \mathrm{E}-09$ & $4.52 E-11$ & $1.22 \mathrm{E}-09$ & $4.52 \mathrm{E}-11$ & $-0.09 \%$ & $-0.06 \%$ \\
\hline 495.10 & $1.36 \mathrm{E}-09$ & $4.76 \mathrm{E}-11$ & $1.36 \mathrm{E}-09$ & $4.76 \mathrm{E}-11$ & $0.27 \%$ & $-0.03 \%$ \\
\hline 500.05 & $1.92 \mathrm{E}-10$ & $5.22 \mathrm{E}-11$ & $1.92 \mathrm{E}-10$ & $5.22 \mathrm{E}-11$ & $0.08 \%$ & $0.01 \%$ \\
\hline 505.00 & 2.32E-10 & 5.52E-11 & $2.20 \mathrm{E}-10$ & 5.47E-11 & $5.25 \%$ & $0.84 \%$ \\
\hline 509.95 & $2.51 \mathrm{E}-10$ & $5.50 \mathrm{E}-11$ & $2.51 E-10$ & 5.50E-11 & $-0.03 \%$ & $-0.03 \%$ \\
\hline 514.90 & $2.86 E-10$ & $5.76 E-11$ & $2.86 E-10$ & $5.76 E-11$ & $0.09 \%$ & $0.03 \%$ \\
\hline 519.85 & $3.24 \mathrm{E}-10$ & $6.02 E-11$ & $3.24 E-10$ & $6.02 E-11$ & $-0.02 \%$ & $0.00 \%$ \\
\hline 524.80 & $3.66 \mathrm{E}-10$ & $6.29 E-11$ & $3.66 \mathrm{E}-10$ & $6.29 E-11$ & $-0.09 \%$ & $0.04 \%$ \\
\hline 529.75 & 4. $13 \mathrm{E}-10$ & $6.56 \mathrm{E}-11$ & 4.13E-10 & $6.56 \mathrm{E}-11$ & $0.05 \%$ & $0.00 \%$ \\
\hline 534.70 & 2.85E-09 & $6.87 E-11$ & 2.85E-09 & 6.87E-11 & $0.06 \%$ & $-0.01 \%$ \\
\hline 539.65 & 3.09E-09 & $7.16 \mathrm{E}-11$ & 3.09E-09 & $7.16 \mathrm{E}-11$ & $-0.05 \%$ & $0.03 \%$ \\
\hline 544.60 & 3.35E-09 & $7.45 E-11$ & 3.35E-09 & $7.45 \mathrm{E}-11$ & $0.04 \%$ & $0.00 \%$ \\
\hline 549.55 & 3.62E-09 & $7.75 \mathrm{E}-11$ & $3.62 E-09$ & $7.75 E-11$ & $0.01 \%$ & $0.04 \%$ \\
\hline 554.50 & $3.90 E-09$ & $7.75 E-11$ & $3.90 E-09$ & $7.75 E-11$ & $0.05 \%$ & $0.01 \%$ \\
\hline 559.45 & 4.20E-09 & 8.05E-11 & 4.20E-09 & 8.05E-11 & $0.07 \%$ & $0.03 \%$ \\
\hline 564.40 & 4.51E-09 & 8.35E-11 & 4.51E-09 & 8.35E-11 & $-0.02 \%$ & $-0.02 \%$ \\
\hline 569.35 & 4.84E-09 & $8.66 \mathrm{E}-11$ & 4.84E-09 & $8.66 \mathrm{E}-11$ & $0.01 \%$ & $0.00 \%$ \\
\hline 574.30 & $5.18 E-09$ & 8.97E-11 & $5.18 E-09$ & $8.97 E-11$ & $-0.05 \%$ & $-0.04 \%$ \\
\hline 579.25 & 5.54E-09 & 9.29E-11 & 5.54E-09 & $9.29 \mathrm{E}-11$ & $-0.02 \%$ & $-0.02 \%$ \\
\hline 584.20 & $5.92 \mathrm{E}-09$ & $9.61 \mathrm{E}-11$ & 5.92E-09 & $9.61 \mathrm{E}-11$ & $0.08 \%$ & $-0.05 \%$ \\
\hline 589.15 & 6.30E-09 & $9.94 \mathrm{E}-11$ & $6.30 \mathrm{E}-09$ & $9.94 E-11$ & $-0.07 \%$ & $-0.03 \%$ \\
\hline 594.10 & 6.71E-09 & $1.03 E-10$ & $6.71 E-09$ & $1.03 \mathrm{E}-10$ & $0.02 \%$ & $0.23 \%$ \\
\hline 599.05 & 7.13E-09 & $1.06 \mathrm{E}-10$ & 7.13E-09 & $1.06 \mathrm{E}-10$ & $0.02 \%$ & $-0.13 \%$ \\
\hline 604.00 & 7.56E-09 & 1.10E-10 & 7.56E-09 & $1.10 \mathrm{E}-10$ & $-0.06 \%$ & $0.39 \%$ \\
\hline 608.95 & 8.02E-09 & $1.13 \mathrm{E}-10$ & 8.02E-09 & $1.13 \mathrm{E}-10$ & $0.06 \%$ & $-0.04 \%$ \\
\hline 613.90 & $8.48 \mathrm{E}-09$ & $1.17 \mathrm{E}-10$ & 8.48E-09 & $1.17 \mathrm{E}-10$ & $-0.03 \%$ & $0.36 \%$ \\
\hline 618.85 & 8.96E-09 & $1.20 \mathrm{E}-10$ & 8.96E-09 & $1.20 \mathrm{E}-10$ & $-0.05 \%$ & $-0.13 \%$ \\
\hline 623.80 & $9.46 \mathrm{E}-09$ & $1.24 E-10$ & $9.46 E-09$ & $1.24 \mathrm{E}-10$ & $-0.02 \%$ & $0.18 \%$ \\
\hline 628.75 & 9.98E-09 & 1.27E-10 & 9.98E-09 & $1.27 \mathrm{E}-10$ & $0.04 \%$ & $-0.36 \%$ \\
\hline 633.70 & $1.05 \mathrm{E}-08$ & $1.31 \mathrm{E}-10$ & $1.05 \mathrm{E}-08$ & $1.31 \mathrm{E}-10$ & $-0.04 \%$ & $-0.14 \%$ \\
\hline 638.65 & 1.10E-08 & $1.35 E-10$ & $1.10 \mathrm{E}-08$ & $1.35 \mathrm{E}-10$ & $-0.44 \%$ & $0.03 \%$ \\
\hline 643.60 & $1.16 \mathrm{E}-08$ & 1.39E-10 & $1.16 \mathrm{E}-08$ & $1.39 \mathrm{E}-10$ & $-0.06 \%$ & $0.16 \%$ \\
\hline 648.55 & $1.22 \mathrm{E}-08$ & $1.43 E-10$ & $1.22 \mathrm{E}-08$ & $1.43 \mathrm{E}-10$ & $0.15 \%$ & $0.24 \%$ \\
\hline 653.50 & $1.28 \mathrm{E}-08$ & $1.47 \mathrm{E}-10$ & $1.28 \mathrm{E}-08$ & $1.47 \mathrm{E}-10$ & $0.23 \%$ & $0.28 \%$ \\
\hline 658.45 & $1.34 \mathrm{E}-08$ & $1.51 E-10$ & $1.34 E-08$ & $1.51 \mathrm{E}-10$ & $0.19 \%$ & $0.29 \%$ \\
\hline 663.40 & $1.40 \mathrm{E}-08$ & $1.55 E-10$ & $1.40 \mathrm{E}-08$ & $1.55 \mathrm{E}-10$ & $0.04 \%$ & $0.26 \%$ \\
\hline 668.35 & $1.46 \mathrm{E}-08$ & $1.59 E-10$ & $1.46 \mathrm{E}-08$ & $1.59 \mathrm{E}-10$ & $-0.18 \%$ & $0.20 \%$ \\
\hline 673.30 & $1.53 \mathrm{E}-08$ & $1.63 E-10$ & $1.53 E-08$ & $1.63 \mathrm{E}-10$ & $0.17 \%$ & $0.12 \%$ \\
\hline 678.25 & $1.59 \mathrm{E}-08$ & $1.67 E-10$ & $1.59 E-08$ & $1.67 \mathrm{E}-10$ & $-0.23 \%$ & $0.00 \%$ \\
\hline 683.20 & $4.81 E-09$ & $1.71 E-10$ & $4.81 \mathrm{E}-09$ & $1.71 \mathrm{E}-10$ & $-0.10 \%$ & $-0.13 \%$ \\
\hline 688.15 & $5.11 E-09$ & $1.76 \mathrm{E}-10$ & $5.11 E-09$ & $1.76 \mathrm{E}-10$ & $0.08 \%$ & $0.28 \%$ \\
\hline 693.10 & $5.41 \mathrm{E}-09$ & $1.80 E-10$ & $5.41 E-09$ & $1.80 \mathrm{E}-10$ & $0.04 \%$ & $0.09 \%$ \\
\hline 698.05 & $5.72 \mathrm{E}-09$ & $1.84 E-10$ & 5.72E-09 & $1.84 \mathrm{E}-10$ & $-0.02 \%$ & $-0.13 \%$ \\
\hline 3.00 & $6.04 \mathrm{E}-09$ & $1.89 E-10$ & $6.04 \mathrm{E}-09$ & $1.89 E-10$ & $-0.08 \%$ & $0.18 \%$ \\
\hline & 6.38E-09 & & 6.38E-09 & $193 \mathrm{~F}-10$ & $0.00 \%$ & $-0.08 \%$ \\
\hline
\end{tabular}




\begin{tabular}{|c|c|c|c|c|c|c|}
\hline 712.90 & 6.85E-09 & $2.00 \mathrm{E}-10$ & 6.85E-09 & $2.00 \mathrm{E}-10$ & $-0.06 \%$ & $0.12 \%$ \\
\hline 717.85 & 7.39E-09 & 2.07E-10 & 7.39E-09 & $2.07 E-10$ & $0.06 \%$ & $-0.02 \%$ \\
\hline 722.80 & 7.94E-09 & $2.14 \mathrm{E}-10$ & 7.94E-09 & $2.14 \mathrm{E}-10$ & $-0.05 \%$ & $-0.23 \%$ \\
\hline 727.75 & 8.53E-09 & $2.22 \mathrm{E}-10$ & 8.53E-09 & $2.22 \mathrm{E}-10$ & $-0.02 \%$ & $-0.07 \%$ \\
\hline 732.70 & $9.15 E-09$ & $2.30 E-10$ & $9.15 E-09$ & $2.30 \mathrm{E}-10$ & $0.02 \%$ & $0.00 \%$ \\
\hline 737.65 & $9.79 E-09$ & $2.38 \mathrm{E}-10$ & 9.79E-09 & $2.38 \mathrm{E}-10$ & $-0.04 \%$ & $-0.01 \%$ \\
\hline 742.60 & $1.05 E-08$ & $2.46 \mathrm{E}-10$ & $1.05 E-08$ & $2.46 \mathrm{E}-10$ & $0.30 \%$ & $-0.10 \%$ \\
\hline 747.55 & $1.12 E-08$ & $2.55 \mathrm{E}-10$ & $1.12 E-08$ & $2.55 E-10$ & $0.23 \%$ & $0.13 \%$ \\
\hline 752.50 & $3.13 E-08$ & $2.63 E-10$ & $3.13 \mathrm{E}-08$ & $2.63 E-10$ & $-0.03 \%$ & $-0.12 \%$ \\
\hline 757.45 & $3.27 E-08$ & $2.72 E-10$ & 3.27E-08 & $2.72 E-10$ & $-0.08 \%$ & $-0.05 \%$ \\
\hline 762.40 & $3.42 E-08$ & $2.81 E-10$ & $3.42 E-08$ & $2.81 E-10$ & $0.08 \%$ & $-0.05 \%$ \\
\hline 767.35 & $3.57 E-08$ & $2.90 E-10$ & $3.57 E-08$ & $2.90 \mathrm{E}-10$ & $0.12 \%$ & $-0.13 \%$ \\
\hline 772.30 & $3.72 E-08$ & $3.00 E-10$ & $3.72 E-08$ & $3.00 \mathrm{E}-10$ & $0.07 \%$ & $0.07 \%$ \\
\hline 777.25 & $3.87 E-08$ & 3.09E-10 & 3.87E-08 & $3.09 E-10$ & $-0.05 \%$ & $-0.14 \%$ \\
\hline 782.20 & $4.03 E-08$ & $3.19 E-10$ & $4.03 E-08$ & $3.19 E-10$ & $0.00 \%$ & $-0.08 \%$ \\
\hline 787.15 & $4.19 E-08$ & $3.29 E-10$ & $4.19 E-08$ & $3.29 E-10$ & $-0.02 \%$ & $-0.09 \%$ \\
\hline 792.10 & $4.36 \mathrm{E}-08$ & $3.40 E-10$ & 4.36E-08 & $3.40 E-10$ & $0.11 \%$ & $0.14 \%$ \\
\hline 797.05 & $4.52 E-08$ & $3.50 E-10$ & 4.52E-08 & $3.50 E-10$ & $-0.05 \%$ & $0.01 \%$ \\
\hline 802.00 & 4.69E-08 & $3.61 E-10$ & $4.69 \mathrm{E}-08$ & $3.61 \mathrm{E}-10$ & $-0.05 \%$ & $0.11 \%$ \\
\hline 806.95 & 4.87E-08 & $3.71 E-10$ & 4.87E-08 & $3.71 \mathrm{E}-10$ & $0.10 \%$ & $-0.12 \%$ \\
\hline 811.90 & $5.04 E-08$ & $3.82 E-10$ & $5.04 \mathrm{E}-08$ & $3.82 E-10$ & $-0.02 \%$ & $-0.12 \%$ \\
\hline 816.85 & $5.22 E-08$ & $3.94 \mathrm{E}-10$ & $5.22 \mathrm{E}-08$ & $3.94 \mathrm{E}-10$ & $0.01 \%$ & $0.07 \%$ \\
\hline 821.80 & $5.40 \mathrm{E}-08$ & $4.05 \mathrm{E}-10$ & 5.40E-08 & $4.05 E-10$ & $-0.02 \%$ & $-0.04 \%$ \\
\hline 826.75 & $5.58 \mathrm{E}-08$ & $4.17 \mathrm{E}-10$ & $5.58 \mathrm{E}-08$ & 4.17E-10 & $-0.09 \%$ & $0.05 \%$ \\
\hline 831.70 & 5.77E-08 & $4.29 E-10$ & 5.77E-08 & $4.29 E-10$ & $-0.02 \%$ & $0.09 \%$ \\
\hline 836.65 & $5.96 E-08$ & $4.41 E-10$ & $5.96 E-08$ & $4.41 E-10$ & $0.00 \%$ & $0.08 \%$ \\
\hline 841.60 & $6.15 E-08$ & $4.53 E-10$ & $6.15 E-08$ & $4.53 E-10$ & $-0.02 \%$ & $0.04 \%$ \\
\hline 846.55 & $6.34 \mathrm{E}-08$ & $4.65 E-10$ & $6.35 E-08$ & $4.65 E-10$ & $-0.08 \%$ & $-0.05 \%$ \\
\hline 851.50 & $6.54 E-08$ & $4.78 \mathrm{E}-10$ & $6.54 \mathrm{E}-08$ & $4.78 E-10$ & $-0.01 \%$ & $0.04 \%$ \\
\hline 856.45 & $6.74 E-08$ & $4.91 E-10$ & $6.74 \mathrm{E}-08$ & $4.91 E-10$ & $0.02 \%$ & $0.09 \%$ \\
\hline 861.40 & $6.94 \mathrm{E}-08$ & $5.04 \mathrm{E}-10$ & $6.94 \mathrm{E}-08$ & $5.04 \mathrm{E}-10$ & $0.02 \%$ & $0.10 \%$ \\
\hline 866.35 & $7.14 \mathrm{E}-08$ & $5.17 \mathrm{E}-10$ & $7.14 \mathrm{E}-08$ & $5.17 E-10$ & $-0.01 \%$ & $0.07 \%$ \\
\hline 871.30 & $7.34 \mathrm{E}-08$ & $5.30 E-10$ & $7.34 \mathrm{E}-08$ & $5.30 \mathrm{E}-10$ & $-0.07 \%$ & $0.01 \%$ \\
\hline 876.25 & $7.55 E-08$ & $5.43 E-10$ & $7.55 E-08$ & $5.43 E-10$ & $-0.01 \%$ & $-0.07 \%$ \\
\hline 881.20 & $7.76 \mathrm{E}-08$ & $5.57 \mathrm{E}-10$ & $7.76 E-08$ & 5.57E-10 & $0.02 \%$ & $-0.01 \%$ \\
\hline 886.15 & 7.97E-08 & $5.71 E-10$ & 7.97E-08 & $5.71 E-10$ & $0.03 \%$ & $0.03 \%$ \\
\hline 891.10 & $8.18 E-08$ & $5.84 \mathrm{E}-10$ & $8.18 \mathrm{E}-08$ & $5.85 E-10$ & $0.02 \%$ & $-0.14 \%$ \\
\hline 896.05 & 8.39E-08 & $5.99 \mathrm{E}-10$ & 8.39E-08 & $5.99 E-10$ & $-0.01 \%$ & $0.02 \%$ \\
\hline 901.00 & 8.60E-08 & $6.13 \mathrm{E}-10$ & 8.60E-08 & $6.13 E-10$ & $-0.05 \%$ & $-0.03 \%$ \\
\hline 905.95 & $8.82 E-08$ & $6.28 E-10$ & 8.82E-08 & $6.28 \mathrm{E}-10$ & $0.01 \%$ & $0.06 \%$ \\
\hline 910.90 & $9.04 \mathrm{E}-08$ & $6.42 \mathrm{E}-10$ & $9.04 \mathrm{E}-08$ & $6.42 E-10$ & $0.05 \%$ & $-0.03 \%$ \\
\hline 915.85 & $9.25 E-08$ & $6.57 E-10$ & $9.25 \mathrm{E}-08$ & $6.57 \mathrm{E}-10$ & $-0.03 \%$ & $0.02 \%$ \\
\hline 920.80 & $9.47 \mathrm{E}-08$ & $6.72 \mathrm{E}-10$ & $9.47 E-08$ & $6.72 \mathrm{E}-10$ & $-0.02 \%$ & $0.04 \%$ \\
\hline 925.75 & $9.69 \mathrm{E}-08$ & $6.87 E-10$ & 9.69E-08 & $6.87 E-10$ & $-0.01 \%$ & $0.04 \%$ \\
\hline 930.70 & $9.91 \mathrm{E}-08$ & $7.02 E-10$ & $9.91 \mathrm{E}-08$ & $7.02 E-10$ & $-0.01 \%$ & $0.03 \%$ \\
\hline 935.65 & $1.01 \mathrm{E}-07$ & $7.17 \mathrm{E}-10$ & $1.01 \mathrm{E}-07$ & $7.17 E-10$ & $-0.32 \%$ & $-0.01 \%$ \\
\hline 940.60 & $1.04 \mathrm{E}-07$ & $7.32 \mathrm{E}-10$ & $1.04 \mathrm{E}-07$ & $7.32 E-10$ & $0.44 \%$ & $-0.06 \%$ \\
\hline 945.55 & $1.06 \mathrm{E}-07$ & $7.48 \mathrm{E}-10$ & $1.06 \mathrm{E}-07$ & $7.48 E-10$ & $0.22 \%$ & $0.01 \%$ \\
\hline 950.50 & $1.08 \mathrm{E}-07$ & $7.63 E-10$ & $1.08 \mathrm{E}-07$ & $7.63 \mathrm{E}-10$ & $0.00 \%$ & $-0.06 \%$ \\
\hline
\end{tabular}




$\begin{array}{rrrrrrr}955.45 & 1.10 \mathrm{E}-07 & 7.79 \mathrm{E}-10 & 1.10 \mathrm{E}-07 & 7.79 \mathrm{E}-10 & -0.22 \% & -0.02 \% \\ 960.40 & 1.12 \mathrm{E}-07 & 7.95 \mathrm{E}-10 & 1.12 \mathrm{E}-07 & 7.95 \mathrm{E}-10 & -0.43 \% & 0.00 \% \\ 965.35 & 1.15 \mathrm{E}-07 & 8.11 \mathrm{E}-10 & 1.15 \mathrm{E}-07 & 8.11 \mathrm{E}-10 & 0.24 \% & 0.01 \% \\ 970.30 & 1.17 \mathrm{E}-07 & 8.27 \mathrm{E}-10 & 1.17 \mathrm{E}-07 & 8.27 \mathrm{E}-10 & 0.02 \% & 0.01 \% \\ 975.25 & 1.19 \mathrm{E}-07 & 8.43 \mathrm{E}-10 & 1.19 \mathrm{E}-07 & 8.43 \mathrm{E}-10 & -0.19 \% & 0.00 \% \\ 980.20 & 1.21 \mathrm{E}-07 & 8.59 \mathrm{E}-10 & 1.21 \mathrm{E}-07 & 8.59 \mathrm{E}-10 & -0.39 \% & -0.03 \% \\ 985.15 & 1.24 \mathrm{E}-07 & 8.75 \mathrm{E}-10 & 1.24 \mathrm{E}-07 & 8.75 \mathrm{E}-10 & 0.22 \% & -0.06 \% \\ 990.10 & 1.26 \mathrm{E}-07 & 8.92 \mathrm{E}-10 & 1.26 \mathrm{E}-07 & 8.92 \mathrm{E}-10 & 0.02 \% & 0.02 \% \\ 995.05 & 1.28 \mathrm{E}-07 & 9.08 \mathrm{E}-10 & 1.28 \mathrm{E}-07 & 9.08 \mathrm{E}-10 & -0.18 \% & -0.03 \%\end{array}$


Table B4. Test Cases 3 through 8

TEST CASE \# 3

\begin{tabular}{ccccccc}
$\begin{array}{c}\text { Downwind } \\
\text { Distance } \\
(\mathrm{m})\end{array}$ & $\begin{array}{c}\text { VENTSAR } \\
\text { X/Q } \\
\left(\mathrm{s} / \mathrm{m}^{\star *} 3\right)\end{array}$ & $\begin{array}{c}\text { VENTSAR XL } \\
\text { X/Q } \\
\left(\mathrm{s} / \mathrm{m}^{\star *} 3\right)\end{array}$ & $\begin{array}{c}\% \text { Diff } \\
\text { X/Q } \\
(\%)\end{array}$ & $\begin{array}{c}\text { Hand Calc } \\
\text { Dose } \\
(\mathrm{nnrem})\end{array}$ & $\begin{array}{c}\text { VENTSAR XL } \\
\text { Dose } \\
(\mathrm{mrem})\end{array}$ & $\begin{array}{c}\% \text { Diff } \\
\text { Dose } \\
(\%)\end{array}$ \\
\hline 10 & $3.66 \mathrm{E}-17$ & $3.66 \mathrm{E}-17$ & $0.00 \%$ & $9.02 \mathrm{E}-13$ & $9.03 \mathrm{E}-13$ & $-0.10 \%$ \\
109 & $8.69 \mathrm{E}-04$ & $8.69 \mathrm{E}-04$ & $0.00 \%$ & $2.14 \mathrm{E}+01$ & $2.14 \mathrm{E}+01$ & $0.19 \%$ \\
208 & $3.93 \mathrm{E}-04$ & $3.93 \mathrm{E}-04$ & $0.00 \%$ & $9.69 \mathrm{E}+00$ & $9.66 \mathrm{EE}+00$ & $0.33 \%$ \\
307 & $2.11 \mathrm{E}-04$ & $2.11 \mathrm{E}-04$ & $0.00 \%$ & $5.20 \mathrm{E}+00$ & $5.18 \mathrm{E}+00$ & $0.31 \%$ \\
406 & $1.35 \mathrm{E}-04$ & $1.35 \mathrm{E}-04$ & $0.00 \%$ & $3.33 \mathrm{E}+00$ & $3.31 \mathrm{E}+00$ & $0.67 \%$ \\
505 & $9.51 \mathrm{E}-05$ & $9.51 \mathrm{E}-05$ & $0.00 \%$ & $2.34 \mathrm{E}+00$ & $2.33 \mathrm{E}+00$ & $0.47 \%$ \\
604 & $7.18 \mathrm{E}-05$ & $7.18 \mathrm{E}-05$ & $0.00 \%$ & $1.77 \mathrm{E}+00$ & $1.76 \mathrm{E}+00$ & $0.58 \%$ \\
703 & $5.67 \mathrm{E}-05$ & $5.67 \mathrm{E}-05$ & $0.00 \%$ & $1.40 \mathrm{E}+00$ & $1.39 \mathrm{E}+00$ & $0.59 \%$ \\
802 & $4.63 \mathrm{E}-05$ & $4.63 \mathrm{E}-05$ & $0.00 \%$ & $1.14 \mathrm{E}+00$ & $1.13 \mathrm{E}+00$ & $0.56 \%$ \\
901 & $3.88 \mathrm{E}-05$ & $3.88 \mathrm{E}-05$ & $0.00 \%$ & $9.56 \mathrm{E}-01$ & $9.51 \mathrm{E}-01$ & $0.55 \%$
\end{tabular}

TEST CASE \# 4

\begin{tabular}{cccc}
$\begin{array}{c}\text { Downwind } \\
\text { Distance } \\
(\mathrm{m})\end{array}$ & $\begin{array}{c}\text { VENTSAR } \\
\text { X/Q } \\
\left(\mathrm{s} / \mathrm{m}^{\star \star 3}\right)\end{array}$ & $\begin{array}{c}\text { VENTSAR XL } \\
\text { X/Q } \\
\left(\mathrm{s} / \mathrm{m}^{\star *} 3\right)\end{array}$ & $\begin{array}{c}\% \text { Diff } \\
\text { X/Q } \\
(\%)\end{array}$ \\
\hline 10 & $0.00 \mathrm{E}+00$ & $0.00 \mathrm{E}+00$ & $\star \star$ \\
109 & $0.00 \mathrm{E}+00$ & $0.00 \mathrm{E}+00$ & $\star \star$ \\
208 & $0.00 \mathrm{E}+00$ & $9.83 \mathrm{E}-300$ & $\star \star$ \\
307 & $0.00 \mathrm{E}+00$ & $3.82 \mathrm{E}-147$ & $\star \star$ \\
406 & $0.00 \mathrm{E}+00$ & $3.19 \mathrm{E}-90$ & $\star \star$ \\
505 & $1.14 \mathrm{E}-62$ & $1.13 \mathrm{E}-62$ & $0.47 \%$ \\
604 & $3.73 \mathrm{E}-47$ & $3.72 \mathrm{E}-47$ & $0.31 \%$ \\
703 & $1.67 \mathrm{E}-37$ & $1.66 \mathrm{E}-37$ & $0.41 \%$ \\
802 & $4.59 \mathrm{E}-31$ & $4.58 \mathrm{E}-31$ & $0.18 \%$ \\
901 & $1.55 \mathrm{E}-26$ & $1.55 \mathrm{E}-26$ & $0.06 \%$
\end{tabular}

TEST CASE \# 5

\begin{tabular}{cccc}
$\begin{array}{c}\text { Downwind } \\
\text { Distance } \\
(\mathrm{m})\end{array}$ & $\begin{array}{c}\text { VENTSAR } \\
\text { X/Q } \\
\left(\mathrm{s} / \mathrm{m}^{\star *} 3\right)\end{array}$ & $\begin{array}{c}\text { VENTSAR XL } \\
\text { X/Q } \\
\left(\mathrm{s} / \mathrm{m}^{* *} 3\right)\end{array}$ & $\begin{array}{c}\% \text { Diff } \\
\text { X/Q } \\
(\%)\end{array}$ \\
\hline 10 & $0.00 \mathrm{E}+00$ & $0.00 \mathrm{E}+00$ & $*$ \\
109 & $1.76 \mathrm{E}-12$ & $1.76 \mathrm{E}-12$ & $0.00 \%$ \\
208 & $2.01 \mathrm{E}-07$ & $2.01 \mathrm{E}-07$ & $0.00 \%$ \\
307 & $6.43 \mathrm{E}-07$ & $6.43 \mathrm{E}-07$ & $0.00 \%$ \\
406 & $1.86 \mathrm{E}-06$ & $1.86 \mathrm{E}-06$ & $0.00 \%$ \\
505 & $2.62 \mathrm{E}-06$ & $2.62 \mathrm{E}-06$ & $0.00 \%$ \\
604 & $2.84 \mathrm{E}-06$ & $2.84 \mathrm{E}-06$ & $0.00 \%$ \\
703 & $2.76 \mathrm{E}-06$ & $2.76 \mathrm{E}-06$ & $0.00 \%$ \\
802 & $2.56 \mathrm{E}-06$ & $2.56 \mathrm{E}-06$ & $0.00 \%$ \\
901 & $2.32 \mathrm{E}-06$ & $2.32 \mathrm{E}-06$ & $0.00 \%$
\end{tabular}

** Value in VENTSAR printed as zero since below cutoff. 


\section{TEST CASE \# 6}

\begin{tabular}{|c|c|c|c|c|c|c|}
\hline $\begin{array}{c}\text { Downwind } \\
\text { Distance } \\
\text { (m) }\end{array}$ & $\begin{array}{l}\text { VENTSAR } \\
99.5 \% \times / Q \\
\left(\mathrm{~s} / \mathrm{m}^{* * 3)}\right.\end{array}$ & $\begin{array}{l}\text { VENTSAR } \\
\text { Annual } X / Q \\
\left(\mathrm{~s} / \mathrm{m}^{* *}\right)\end{array}$ & $\begin{array}{l}\text { VENTSAR XL } \\
99.5 \% \mathrm{X} / \mathrm{Q} \\
\left(\mathrm{s} / \mathrm{m}^{\star *} 3\right)\end{array}$ & $\begin{array}{l}\text { VENTSAR XL } \\
\text { Annual } X / Q \\
\left(\mathrm{~s} / \mathrm{m}^{\star *}\right)\end{array}$ & $\begin{array}{c}\% \text { Diff } \\
99.5 \% \times / Q \\
(\%)\end{array}$ & $\begin{array}{c}\text { \% Diff } \\
\text { Annual } \\
X / Q \\
(\%)\end{array}$ \\
\hline 10 & $0.00 E+00$ & $0.00 \mathrm{E}+00$ & $3.46 \mathrm{E}-138$ & $2.74 \mathrm{E}-140$ & $\star \star$ & $\star \star$ \\
\hline 109 & $1.40 \mathrm{E}-05$ & $1.11 \mathrm{E}-07$ & $1.40 \mathrm{E}-05$ & $1.11 E-07$ & $0.00 \%$ & $0.00 \%$ \\
\hline 208 & 2.00E-05 & 2.63E-07 & 2.00E-05 & 2.63E-07 & $0.00 \%$ & $0.00 \%$ \\
\hline 307 & $1.48 \mathrm{E}-05$ & 2.43E-07 & $1.48 E-05$ & 2.43E-07 & $0.00 \%$ & $0.00 \%$ \\
\hline 406 & $1.29 \mathrm{E}-05$ & $2.14 \mathrm{E}-07$ & 1.29E-05 & $2.14 \mathrm{E}-07$ & $0.00 \%$ & $0.00 \%$ \\
\hline 505 & $1.06 \mathrm{E}-05$ & 1.91E-07 & $1.06 \mathrm{E}-05$ & $1.91 \mathrm{E}-07$ & $0.00 \%$ & $0.00 \%$ \\
\hline 604 & $9.21 E-06$ & $1.73 E-07$ & $9.21 \mathrm{E}-06$ & $1.73 E-07$ & $0.00 \%$ & $0.00 \%$ \\
\hline 703 & 8.43E-06 & 1.60E-07 & 8.43E-06 & 1.60E-07 & $0.00 \%$ & $0.00 \%$ \\
\hline 802 & 8.39E-06 & 1.50E-07 & 8.39E-06 & $1.50 \mathrm{E}-07$ & $0.00 \%$ & $0.00 \%$ \\
\hline 901 & 7.30E-06 & $1.42 E-07$ & 7.30E-06 & $1.42 E-07$ & $0.00 \%$ & $0.00 \%$ \\
\hline
\end{tabular}

TEST CASE \# 6 continued

\begin{tabular}{cccc}
$\begin{array}{c}\text { Downwind } \\
\text { Distance } \\
(\mathrm{m})\end{array}$ & $\begin{array}{c}\text { Hand Calc } \\
\text { Dose } \\
(\mathrm{mrem})\end{array}$ & $\begin{array}{c}\text { VENTSAR XL } \\
\text { Dose } \\
(\mathrm{mrem})\end{array}$ & $\begin{array}{c}\text { Difference } \\
\text { Dose } \\
(\%)\end{array}$ \\
\hline 10 & $0.00 \mathrm{E}+00$ & $1.42 \mathrm{E}-133$ & $\star \star$ \\
109 & $5.75 \mathrm{E}-01$ & $5.74 \mathrm{E}-01$ & $0.14 \%$ \\
208 & $8.22 \mathrm{E}-01$ & $8.22 \mathrm{E}-01$ & $0.00 \%$ \\
307 & $6.08 \mathrm{E}-01$ & $6.08 \mathrm{E}-01$ & $0.02 \%$ \\
406 & $5.30 \mathrm{E}-01$ & $5.29 \mathrm{E}-01$ & $0.24 \%$ \\
505 & $4.35 \mathrm{E}-01$ & $4.35 \mathrm{E}-01$ & $0.04 \%$ \\
604 & $3.78 \mathrm{E}-01$ & $3.78 \mathrm{E}-01$ & $0.04 \%$ \\
703 & $3.46 \mathrm{E}-01$ & $3.46 \mathrm{E}-01$ & $0.02 \%$ \\
802 & $3.45 \mathrm{E}-01$ & $3.44 \mathrm{E}-01$ & $0.09 \%$ \\
901 & $3.00 \mathrm{E}-01$ & $3.00 \mathrm{E}-01$ & $0.13 \%$
\end{tabular}

** Value in VENTSAR printed as zero since below cutoff. 


\begin{tabular}{|c|c|c|c|c|c|c|}
\hline $\begin{array}{l}\text { Downwind } \\
\text { Distance } \\
(\mathrm{m})\end{array}$ & $\begin{array}{l}\text { VENTSAR } \\
99.5 \% \times / Q \\
\left(\mathrm{~s} / \mathrm{m}^{* *} 3\right)\end{array}$ & $\begin{array}{l}\text { VENTSAR } \\
\text { Annual } X / Q \\
\left(\mathrm{~s} / \mathrm{m}^{\star *} 3\right)\end{array}$ & $\begin{array}{l}\text { VENTSAR XL } \\
99.5 \% \times / Q \\
\left(\mathrm{~s} / \mathrm{m}^{* * 3)}\right.\end{array}$ & $\begin{array}{l}\text { VENTSAR XL } \\
\text { Annual } X / Q \\
\left(\mathrm{~s} / \mathrm{m}^{* *} 3\right)\end{array}$ & $\begin{array}{c}\text { \% Diff } \\
99.5 \% \times / Q \\
(\%)\end{array}$ & $\begin{array}{c}\% \text { Diff } \\
\text { Annual } \\
X / Q \\
(\%)\end{array}$ \\
\hline 10 & $0.00 \mathrm{E}+00$ & $0.00 E+00$ & $0.00 \mathrm{E}+00$ & $0.00 \mathrm{E}+00$ & ** & ** \\
\hline 109 & $0.00 E+00$ & $2.86 \mathrm{E}-28$ & $1.05 E-96$ & $2.85 E-28$ & ** & $0.22 \%$ \\
\hline 208 & $6.78 \mathrm{E}-45$ & $1.56 E-16$ & $6.78 E-45$ & $1.56 \mathrm{E}-16$ & $0.00 \%$ & $-0.12 \%$ \\
\hline 307 & $5.89 E-32$ & $1.93 E-13$ & $5.89 E-32$ & $1.93 \mathrm{E}-13$ & $0.01 \%$ & $-0.15 \%$ \\
\hline 406 & $1.76 \mathrm{E}-27$ & 2.40E-12 & $1.76 \mathrm{E}-27$ & 2.4.0E-12 & $0.09 \%$ & $-0.14 \%$ \\
\hline 505 & 2.30E-17 & $7.98 \mathrm{E}-12$ & 2.30E-17 & $7.98 \mathrm{E}-12$ & $0.02 \%$ & $0.01 \%$ \\
\hline 604 & $1.27 \mathrm{E}-14$ & $1.61 \mathrm{E}-11$ & $1.27 E-14$ & $1.61 \mathrm{E}-11$ & $0.27 \%$ & $0.07 \%$ \\
\hline 703 & $6.47 E-13$ & $2.61 \mathrm{E}-11$ & $6.47 E-13$ & $2.61 \mathrm{E}-11$ & $0.04 \%$ & $0.08 \%$ \\
\hline 802 & $1.09 \mathrm{E}-11$ & $4.03 E-11$ & 1.09E-11 & $4.03 \mathrm{E}-11$ & $-0.40 \%$ & $-0.08 \%$ \\
\hline 901 & $1.01 \mathrm{E}-10$ & $6.40 \mathrm{E}-11$ & $1.01 \mathrm{E}-10$ & $6.40 \mathrm{E}-11$ & $-0.37 \%$ & $0.08 \%$ \\
\hline
\end{tabular}

TEST CASE \# 8

\begin{tabular}{cccc}
$\begin{array}{c}\text { Downwind } \\
\text { Distance } \\
(\mathrm{m})\end{array}$ & $\begin{array}{c}\text { VENTSAR } \\
99.5 \% \times / Q \\
\left(\mathrm{~s} / \mathrm{m}^{\star \star 3}\right)\end{array}$ & $\begin{array}{c}\text { VENTSAR XL } \\
99.5 \% \times / \mathrm{Q} \\
\left(\mathrm{s} / \mathrm{m}^{\star *}\right)\end{array}$ & $\begin{array}{c}\% \text { Diff } \\
99.5 \% \times / \mathrm{X} \\
(\%)\end{array}$ \\
\hline 10 & $1.17 \mathrm{E}-02$ & $1.17 \mathrm{E}-02$ & $-0.37 \%$ \\
109 & $1.18 \mathrm{E}-04$ & $1.18 \mathrm{E}-04$ & $0.04 \%$ \\
208 & $3.48 \mathrm{E}-05$ & $3.48 \mathrm{E}-05$ & $0.08 \%$ \\
307 & $1.68 \mathrm{E}-05$ & $1.68 \mathrm{E}-05$ & $0.04 \%$ \\
406 & $1.00 \mathrm{E}-05$ & $1.00 \mathrm{E}-05$ & $0.01 \%$ \\
505 & $6.69 \mathrm{E}-06$ & $6.69 \mathrm{E}-06$ & $0.03 \%$ \\
604 & $4.82 \mathrm{E}-06$ & $4.82 \mathrm{E}-06$ & $0.07 \%$ \\
703 & $3.65 \mathrm{E}-06$ & $3.65 \mathrm{E}-06$ & $-0.02 \%$ \\
802 & $2.87 \mathrm{E}-06$ & $2.87 \mathrm{E}-06$ & $-0.10 \%$ \\
901 & $2.33 \mathrm{E}-06$ & $2.33 \mathrm{E}-06$ & $0.14 \%$
\end{tabular}

** Value in VENTSAR printed as zero since below cutoff. 
APPENDIX C ADDITIONAL TEST CASE DEMONSTRATION 


\section{APPENDIX C. ADDITIONAL TEST CASE DEMONSTRATION}

Four additional test cases were created to ensure proper application of methodologies. Parameters for the additional test cases are shown in Table C1. Results for test cases 9-12 are shown in Table C2 for selected downwind distances.

\section{Table C1. Test Cases Parameters}

\begin{tabular}{|c|c|c|c|c|}
\hline Parameter & Case 9 & Case 10 & Case 11 & Case 12 \\
\hline Consider Plume Rise & NO & NO & YES & NO \\
\hline Area of Release & $\#$ & $\#$ & $C$ & A \\
\hline Building Height & 10 & 10 & 40 & 10 \\
\hline Building Width & 100 & 100 & 30 & 10 \\
\hline Building Length & 100 & 100 & 100 & 10 \\
\hline Penthouse Height & 5 & 5 & 5 & 5 \\
\hline Penthouse Width & 90 & 90 & 10 & 5 \\
\hline Penthouse Length & 90 & 90 & 30 & 5 \\
\hline Bldg. to Penthouse & 5 & 5 & 70 & 1 \\
\hline Min. Vent to Receptor & 10 & 10 & 10 & 1 \\
\hline Max. Vent to Receptor & 510 & 510 & 1010 & 101 \\
\hline Compass Sector & $s$ & $\mathrm{~s}$ & SSE & $E$ \\
\hline Vent to Roof Edge & -10 & -10 & 70 & 20 \\
\hline Vent Height & 10 & 10 & 0 & 0 \\
\hline Radioactive Release? & YES & YES & NO & YES \\
\hline Release Rate (Ci/min) & 1 & 1 & $-\infty$ & 1 \\
\hline Pollutant Mole Fraction & 0.000001 & 0.000001 & - & 0.000001 \\
\hline Vent-Gas Flow Rate $\left(m^{\wedge} 3 / s\right)$ & 500 & 500 & 1000 & 500 \\
\hline Met. Averaging? & YES & NO & YES & NO \\
\hline Probability Level & 0.005 & $=$ & 0.005 & - \\
\hline Wind Speed $(\mathrm{m} / \mathrm{s})$ & - & 4.5 & - & 3 \\
\hline Stability Class & ming & $\mathrm{D}$ & - & B \\
\hline Vent Diameter & 1 & 1 & 1 & 1 \\
\hline Vent-Gas Molecular Weight & 29 & 29 & 190 & 30 \\
\hline Vent-Gas Temp(C) & 30 & 30 & 100 & 20 \\
\hline Ambient Air Temp(C) & 30 & 30 & 20 & 20 \\
\hline Calculate Dose & $Y$ & $\mathrm{~N}$ & $\mathrm{~N}$ & $\mathrm{~N}$ \\
\hline Breathing Rate & 10500 & & & \\
\hline \multirow{10}{*}{ Radionuclide, Source Term } & $\mathrm{H}-3,2 \mathrm{Gi}$ & & & \\
\hline & \multicolumn{2}{|l|}{$\mathrm{Sr}-90,3 \mathrm{C}$} & & \\
\hline & $Y-90,4 \mathrm{Ci}$ & & & \\
\hline & \multicolumn{2}{|c|}{$\mathrm{Cs}-137,5 \mathrm{Ci}$} & & \\
\hline & \multicolumn{2}{|c|}{$\mathrm{Ba}-137 \mathrm{~m}, 6 \mathrm{Ci}$} & & \\
\hline & \multicolumn{2}{|l|}{$\mathrm{Rn}-220,9 \mathrm{Ci}$} & & \\
\hline & \multicolumn{2}{|l|}{$\mathrm{U}-235,3 \mathrm{Ci}$} & & \\
\hline & \multicolumn{2}{|l|}{$\mathrm{U}-238,4 \mathrm{Ci}$} & & \\
\hline & \multicolumn{2}{|c|}{$\mathrm{Pu}-238,3 \mathrm{Ci}$} & & \\
\hline & \multicolumn{2}{|c|}{$\mathrm{Am}-242,3.33 \mathrm{Ci}$} & & \\
\hline
\end{tabular}


Table C2. Comparison of VENTSAR XL and VENTSAR for Additional Test Cases

\section{TEST CASE \#9}

\begin{tabular}{|c|c|c|c|c|c|c|}
\hline $\begin{array}{c}\text { Downwind } \\
\text { Distance } \\
(m) \\
\end{array}$ & $\begin{array}{r}\text { VENTSAR } \\
99.5 \% \times / Q \\
\left(\mathrm{~s} / \mathrm{m}^{\star \star 3}\right) \\
\end{array}$ & $\begin{array}{l}\text { VENTSAR } \\
\text { Annual X/Q } \\
\left(\mathrm{s} / \mathrm{m}^{\star \star} 3\right) \\
\end{array}$ & $\begin{array}{l}\text { VENTSAR XL } \\
99.5 \% \times / Q \\
\left(\mathrm{~s} / \mathrm{m}^{\star \star} 3\right) \\
\end{array}$ & $\begin{array}{l}\text { VENTSAR XL } \\
\text { Annual X/Q } \\
\left(\mathrm{s} / \mathrm{m}^{\star *} 3\right)\end{array}$ & $\begin{array}{c}\text { \% Diff } \\
99.5 \% \times / Q \\
(\%)\end{array}$ & $\begin{array}{c}\% \text { Diff } \\
\text { Annual } \\
X / Q \\
(\%) \\
\end{array}$ \\
\hline 10 & $9.14 \mathrm{E}-08$ & $9.66 \mathrm{E}-10$ & $9.14 \mathrm{E}-08$ & $9.66 \mathrm{E}-10$ & $0.00 \%$ & $0.00 \%$ \\
\hline 60 & $8.42 E-04$ & $2.45 \mathrm{E}-05$ & $8.42 E-04$ & $2.45 \mathrm{E}-05$ & $0.00 \%$ & $0.00 \%$ \\
\hline 110 & $2.38 \mathrm{E}-04$ & $4.59 \mathrm{E}-06$ & $2.38 \mathrm{E}-04$ & 4.59E-06 & $0.00 \%$ & $0.00 \%$ \\
\hline 160 & $8.38 \mathrm{E}-05$ & $1.84 \mathrm{E}-06$ & $8.38 \mathrm{E}-05$ & $1.84 \mathrm{E}-06$ & $0.00 \%$ & $0.00 \%$ \\
\hline 210 & $7.61 \mathrm{E}-05$ & $1.52 \mathrm{E}-06$ & $7.61 \mathrm{E}-05$ & $1.52 \mathrm{E}-06$ & $0.00 \%$ & $0.00 \%$ \\
\hline 260 & $5.61 \mathrm{E}-05$ & $1.23 \mathrm{E}-06$ & $5.61 \mathrm{E}-05$ & $1.23 \mathrm{E}-06$ & $0.00 \%$ & $0.00 \%$ \\
\hline 310 & $6.12 \mathrm{E}-05$ & $1.00 \mathrm{E}-06$ & $6.12 \mathrm{E}-05$ & $1.00 \mathrm{E}-06$ & $0.00 \%$ & $0.00 \%$ \\
\hline 360 & $4.97 \mathrm{E}-05$ & 8.36E-07 & 4.97E-05 & 8.36E-07 & $0.00 \%$ & $0.00 \%$ \\
\hline 410 & $4.08 \mathrm{E}-05$ & $7.15 \mathrm{E}-07$ & $4.08 \mathrm{E}-05$ & $7.15 \mathrm{E}-07$ & $0.00 \%$ & $0.00 \%$ \\
\hline 460 & $3.65 \mathrm{E}-05$ & $6.21 \mathrm{E}-07$ & $3.65 \mathrm{E}_{-}-05$ & $6.21 \mathrm{E}-07$ & $0.00 \%$ & $0.00 \%$ \\
\hline
\end{tabular}

TEST CASE \#9 continued

Downwind Hand Calc

Distance

\begin{tabular}{cccc}
$(\mathrm{m})$ & $(\mathrm{mrem})$ & $(\mathrm{mrem})$ & \multicolumn{1}{c}{$(\%)$} \\
\hline 10 & $6.77 \mathrm{E}+01$ & $6.76 \mathrm{E}+01$ & $0.13 \%$ \\
60 & $6.24 \mathrm{E}+05$ & $6.23 \mathrm{E}+05$ & $0.09 \%$ \\
110 & $1.76 \mathrm{E}+05$ & $1.76 \mathrm{E}+05$ & $0.15 \%$ \\
160 & $6.21 \mathrm{E}+04$ & $6.21 \mathrm{E}+04$ & $-0.06 \%$ \\
210 & $5.64 \mathrm{E}+04$ & $5.64 \mathrm{E}+04$ & $-0.07 \%$ \\
260 & $4.15 \mathrm{E}+04$ & $4.15 \mathrm{E}+04$ & $0.11 \%$ \\
310 & $4.53 \mathrm{E}+04$ & $4.53 \mathrm{E}+04$ & $0.05 \%$ \\
360 & $3.68 \mathrm{E}+04$ & $3.68 \mathrm{E}+04$ & $0.02 \%$ \\
410 & $3.02 \mathrm{E}+04$ & $3.02 \mathrm{E}+04$ & $0.05 \%$ \\
460 & $2.70 \mathrm{E}+04$ & $2.70 \mathrm{E}+04$ & $0.12 \%$
\end{tabular}

TEST CASE \# 10

\begin{tabular}{cccc}
$\begin{array}{c}\text { Downwind } \\
\text { Distance } \\
(\mathrm{m})\end{array}$ & $\begin{array}{c}\text { VENTSAR } \\
\text { X/Q } \\
\left(\mathrm{s} / \mathrm{m}^{\star *} 3\right)\end{array}$ & $\begin{array}{c}\text { VENTSAR XL } \\
\text { X/Q } \\
\left(\mathrm{s} / \mathrm{m}^{* * 3)}\right.\end{array}$ & $\begin{array}{c}\% \text { Diff } \\
\text { X/Q } \\
(\%)\end{array}$ \\
\hline 10 & $3.17 \mathrm{E}-63$ & $3.17 \mathrm{E}-63$ & $0.00 \%$ \\
60 & $9.39 \mathrm{E}-04$ & $9.39 \mathrm{E}-04$ & $0.00 \%$ \\
110 & $1.60 \mathrm{E}-04$ & $1.60 \mathrm{E}-04$ & $0.00 \%$ \\
160 & $2.87 \mathrm{E}-05$ & $2.87 \mathrm{E}-05$ & $0.00 \%$ \\
210 & $4.13 \mathrm{E}-05$ & $4.13 \mathrm{E}-05$ & $0.00 \%$ \\
260 & $4.98 \mathrm{E}-05$ & $4.98 \mathrm{E}-05$ & $0.00 \%$ \\
310 & $5.20 \mathrm{E}-05$ & $5.20 \mathrm{E}-05$ & $0.00 \%$ \\
360 & $4.99 \mathrm{E}-05$ & $4.99 \mathrm{E}-05$ & $0.00 \%$ \\
410 & $4.60 \mathrm{E}-05$ & $4.60 \mathrm{E}-05$ & $0.00 \%$ \\
460 & $4.15 \mathrm{E}-05$ & $4.15 \mathrm{E}-05$ & $0.00 \%$
\end{tabular}


Table C2. Cont. Comparison of VENTSAR XL and VENTSAR for Additional Test Cases

\section{TEST CASE \#11}

\begin{tabular}{|c|c|c|c|c|c|c|}
\hline $\begin{array}{c}\text { Downwind } \\
\text { Distance } \\
(\mathrm{m})\end{array}$ & $\begin{array}{r}\text { VENTSAR } \\
99.5 \% \times / Q \\
\left(\mathrm{~s} / \mathrm{m}^{\star *}\right) \\
\end{array}$ & $\begin{array}{l}\text { VENTSAR } \\
\text { Annual X/Q } \\
\left(\mathrm{s} / \mathrm{m}^{\star *}\right)\end{array}$ & $\begin{array}{l}\text { VENTSAR XL } \\
99.5 \% \times / Q \\
\left(\mathrm{~s} / \mathrm{m}^{\star *} 3\right) \\
\end{array}$ & $\begin{array}{l}\text { VENTSAR XL } \\
\text { Annual X/Q } \\
\left(\mathrm{s} / \mathrm{m}^{\star * 3)}\right.\end{array}$ & $\begin{array}{c}\% \text { Diff } \\
99.5 \% \\
X / Q \\
(\%) \\
\end{array}$ & $\begin{array}{c}\text { \% Diff } \\
\text { Annual } \\
X / Q \\
(\%) \\
\end{array}$ \\
\hline 10 & $0.00 E+00$ & $0.00 \mathrm{E}+00$ & $0.00 \mathrm{E}+00$ & $1.39 \mathrm{E}-116$ & $\hbar \star$ & 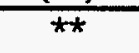 \\
\hline 110 & $0.00 E+00$ & $1.64 \mathrm{E}-31$ & $4.29 E-96$ & $1.64 \mathrm{E}-31$ & ** & $0.00 \%$ \\
\hline 210 & $2.19 \mathrm{E}-42$ & $1.08 \mathrm{E}-17$ & 2. $19 \mathrm{E}-42$ & $1.08 \mathrm{E}-17$ & $0.00 \%$ & $0.00 \%$ \\
\hline 310 & $2.31 \mathrm{E}-25$ & & $2.31 E-25$ & & $0.00 \%$ & $0.00 \%$ \\
\hline 410 & $1.21 \mathrm{E}-18$ & $4.89 E-13$ & $1.21 \mathrm{E}-18$ & $4.89 \mathrm{E}-13$ & $0.00 \%$ & $0.00 \%$ \\
\hline 510 & $2.94 \mathrm{E}-15$ & $1.90 \mathrm{E}-12$ & $2.94 \mathrm{E}-15$ & $1.90 \mathrm{E}-12$ & $0.00 \%$ & $0.00 \%$ \\
\hline 610 & $2.72 \mathrm{E}-13$ & & & & $0.00 \%$ & $0.00 \%$ \\
\hline 710 & $4.82 \mathrm{E}-12$ & $6.34 \mathrm{E}-12$ & $4.82 \mathrm{E}-12$ & $6.34 \mathrm{E}-12$ & $0.00 \%$ & $0.00 \%$ \\
\hline 810 & & $9.16 \mathrm{E}-12$ & $3.38 \mathrm{E}-11$ & $9.16 \mathrm{E}-12$ & $0.00 \%$ & $0.00 \%$ \\
\hline 910 & $1.35 \mathrm{E}-10$ & $1.29 E-11$ & $1.35 \mathrm{E}-10$ & $1.29 \mathrm{E}-11$ & $0.00 \%$ & $0.00 \%$ \\
\hline
\end{tabular}

TEST CASE \# 12

\begin{tabular}{cccc}
$\begin{array}{c}\text { Downwind } \\
\text { Distance } \\
(\mathrm{m})\end{array}$ & $\begin{array}{c}\text { VENTSAR } \\
\text { X/Q } \\
\left(\mathrm{s} / \mathrm{m}^{\star *} 3\right)\end{array}$ & $\begin{array}{c}\text { VENTSAR XL } \\
\text { X/Q } \\
\left(\mathrm{s} / \mathrm{m}^{\star *} 3\right)\end{array}$ & $\begin{array}{c}\% \text { Diff } \\
\text { X/Q } \\
(\%)\end{array}$ \\
\hline 10 & $2.35 \mathrm{E}-03$ & $2.35 \mathrm{E}-03$ & $0.00 \%$ \\
20 & $1.57 \mathrm{E}-03$ & $1.57 \mathrm{E}-03$ & $0.00 \%$ \\
30 & $1.10 \mathrm{E}-03$ & $1.10 \mathrm{E}-03$ & $0.00 \%$ \\
40 & $8.05 \mathrm{E}-04$ & $8.05 \mathrm{E}-04$ & $0.00 \%$ \\
50 & $6.09 \mathrm{E}-04$ & $6.09 \mathrm{E}-04$ & $0.00 \%$ \\
60 & $4.75 \mathrm{E}-04$ & $4.75 \mathrm{E}-04$ & $0.00 \%$ \\
70 & $3.81 \mathrm{E}-04$ & $3.81 \mathrm{E}-04$ & $0.00 \%$ \\
80 & $3.11 \mathrm{E}-04$ & $3.11 \mathrm{E}-04$ & $0.00 \%$ \\
90 & $2.59 \mathrm{E}-04$ & $2.59 \mathrm{E}-04$ & $0.00 \%$ \\
100 & $2.19 \mathrm{E}-04$ & $2.19 \mathrm{E}-04$ & $0.00 \%$
\end{tabular}

**Value determined in VENTSAR is below threshold value for printout. 
APPENDIX D. HAND CALCULATIONS 


\section{APPENDIX D. HAND CALCULATIONS}

Independent hand calculations were performed to demonstrate that VENTSAR XL was correctly applying the methodologies previously discussed.

\subsection{Plume Rise Options}

For a downwind distance of $10 \mathrm{~m}$, the following calculations were performed to verify plume rise methodologies using the parameters shown in Table 4.

Buoyancy Effects

$$
\begin{aligned}
& D R H O=\frac{M W_{a} T_{e}-M W_{e} T_{a}}{2 M W_{a} T_{e}} \\
& M W_{e}=M F C T \times M W_{e}+(1-M F C T) M W_{a} \\
& M W_{e}=1.8 \mathrm{E}-03 \times 78.12+(1-1.8 \mathrm{E}-03) 28.9 \\
& M W_{e}=29.05
\end{aligned}
$$

Using all other known parameters the following is determined.

$D R H O=0.0305$

The buoyancy flux, $F_{0}$, is then calculated using the following equation:

$$
\begin{aligned}
& F_{o}=2.0 \times G \times D R H O \times C M S \\
& F_{o}=2.0 \times 9.8\left(\frac{\mathrm{m}}{\mathrm{s}^{2}}\right) \times 0.0305 \times 50\left(\frac{\mathrm{m}^{3}}{\mathrm{~s}}\right)=29.87 \mathrm{~m}^{4} / \mathrm{s}^{3}
\end{aligned}
$$

Since buoyancy flux is less than 55.0, XSTR is calculated as follows:

$$
X S T R=49.0 \times F_{o}^{0.625}=49.0 \times 29.87^{0.625}=409.5 \mathrm{~m}
$$

The weather conditions are neutral (D stability) the value of the stability parameter, $\mathrm{S}$, is one. Since $\mathrm{X}<\mathrm{XSTR}$, the increase in release height due to buoyancy is:

$$
\Delta h_{B}=1.6 \frac{F_{0}^{1 / 3} X^{2 / 3}}{U}=1.6 \frac{29.87^{1 / 3} 10^{2 / 3}}{6}=3.84 \mathrm{~m}
$$

Momentum Effects: The velocity of the plume, $V_{e}$, is calculated as follows:

$$
\begin{aligned}
& V_{e}=C M S / \text { AREA } \\
& V_{e}=50 \frac{\mathrm{m}^{3}}{\mathrm{~s}} /\left[\pi(0.5 \mathrm{~m})^{2}\right]=63.66 \frac{\mathrm{m}}{\mathrm{s}}
\end{aligned}
$$




$$
\begin{aligned}
& B 1=\frac{0.75 \times \pi}{\left(0.4+1.2 \times U / V_{e}\right)^{2}}=\frac{0.75 \times \pi}{\left(0.4+1.2 \times 6.0 \frac{\mathrm{m}}{\mathrm{s}} / 63.66 \frac{\mathrm{m}}{\mathrm{s}}\right)^{2}}=8.95 \\
& M_{o}=\left[\frac{M W_{e} T_{a}}{M W_{a} T_{e}}\right]^{0.5}=\left[\frac{29.05 \times 293}{28.96 \times 313}\right]^{0.5}=0.97
\end{aligned}
$$$$
D H M O M=\frac{D \times V_{e} M_{o}}{U}=\frac{1 \mathrm{~m} \times 63.66 \frac{\mathrm{m}}{\mathrm{s}} \times 0.97}{6 \frac{\mathrm{m}}{\mathrm{s}}}=10.29
$$

Using the above parameters, XTEST can be calculated as follows:

$$
X T E S T=\frac{27.0 * D H M O M}{B 1}=\frac{27.0 * 10.29}{8.95}=31.04 \mathrm{~m}
$$

Since $\mathrm{X}$ is less than XTEST

$$
\Delta h_{m}=\left(B 1 * X * D H M O M^{2}\right)^{1 / 3}=\left(8.95 * 10 * 10.29^{2}\right)^{1 / 3}=21.15 \mathrm{~m}
$$

There is no downwash since $\mathrm{V}_{\mathrm{e}} / \mathrm{U}>1.5$, and the effective change in plume height is

$$
h(x)=h_{s}-\Delta h_{D}+\Delta h_{B}(x)+\Delta h_{M}(x)=20.0-0.00+3.84+21.15=44.99 \mathrm{~m}
$$

The concentration is calculated as follows:

$$
\frac{\chi}{Q}=\frac{1}{2 \pi \sigma_{y} \sigma_{z} U_{S}}\left[e^{-\left(\frac{\left(z-h_{e}\right)^{2}}{2 \sigma_{z}^{2}}\right)}+e^{-\left(\frac{\left(z+h_{e}\right)^{2}}{2 \sigma_{z}^{2}}\right)}\right]
$$

For $\mathrm{D}$ stability $10 \mathrm{~m}$ downwind of release location

$$
\begin{array}{ll}
\sigma_{\mathrm{y}}=\frac{\sigma_{\theta} \mathrm{x}}{1+0.031(\mathrm{x})^{0.46}} & \sigma_{\mathrm{z}}=0.06 \mathrm{x}(1+0.0015 \mathrm{x})^{-0.5} \\
\sigma_{\mathrm{y}}=\frac{0.218 * 10 \mathrm{~m}}{1+0.031(10)^{0.46}} & \sigma_{\mathrm{z}}=0.06^{*} 10 \mathrm{~m}(1+0.0015 * 10)^{-0.5} \\
\sigma_{\mathrm{y}}=2.001 \mathrm{~m} & \sigma_{\mathrm{z}}=0.596 \mathrm{~m}
\end{array}
$$


$\frac{\chi}{\mathrm{Q}}=\frac{\mathrm{e}^{-0.5(44.99 / 0.596)^{2}}+\mathrm{e}^{-0.5(44.99 / 0.596)^{2}}}{2^{*} 3.14 * 2.001 \mathrm{~m}^{*} 0.596 \mathrm{~m}^{*} 6 \mathrm{~m} / \mathrm{s}}=0.0 \mathrm{E}+00 \mathrm{~s} / \mathrm{m}^{3}$

The following hand calculation is for a downwind distance of $X=200 \mathrm{~m}$.

Using the same constants as above and since X $<$ XSTR

$$
\Delta h_{B}=1.6 \frac{F_{0}^{1 / 3} X^{2 / 3}}{U}=1.6 \frac{29.87^{1 / 3} 200^{2 / 3}}{6}=28.30 \mathrm{~m}
$$

For momentum effects, $\mathrm{X}>\mathrm{XTEST}$ yielding

$$
\begin{aligned}
& \Delta h_{m}=3 * D H M O M=3 * 10.29=30.87 \mathrm{~m} \\
& h(x)=20.0-0.00+28.30+30.87=79.17 \mathrm{~m}
\end{aligned}
$$

For D stability $200 \mathrm{~m}$ downwind of release location

$$
\begin{aligned}
& \sigma_{\mathrm{y}}=\frac{\sigma_{\theta} \mathrm{x}}{1+0.031(\mathrm{x})^{0.46}} \quad \sigma_{\mathrm{z}}=0.06 \mathrm{x}(1+0.0015 \mathrm{x})^{-0.5} \\
& \sigma_{\mathrm{y}}=\frac{0.218 * 200 \mathrm{~m}}{1+0.031(200)^{0.46}} \quad \sigma_{\mathrm{z}}=0.06^{*} 200 \mathrm{~m}(1+0.0015 * 200)^{-0.5} \\
& \sigma_{\mathrm{y}}=32.21 \mathrm{~m} \quad \sigma_{\mathrm{z}}=10.52 \mathrm{~m} \\
& \frac{\chi}{\mathrm{Q}}=\frac{\mathrm{e}^{-0.5(79.17 / 10.525)^{2}}+\mathrm{e}^{-0.5(79.17 / 10.525)^{2}}}{2^{*} 3.14^{*} 32.21 \mathrm{~m}^{*} 10.525 \mathrm{~m}^{*} 6 \mathrm{~m} / \mathrm{s}}=8.21 \mathrm{E}-17 \mathrm{~s} / \mathrm{m}^{3}
\end{aligned}
$$

The following hand calculation is for a downwind distance of $X=1000 \mathrm{~m}$.

Since $X>X S T R$ the same equation is used as above except $X$ is replaced with the value of XSTR.

$$
\begin{aligned}
\Delta h_{B} & =1.6 \frac{F_{o}^{1 / 3} X S T R^{2 / 3}}{U} \\
\Delta h_{B} & =1.6 \frac{29.87^{1 / 3} 409.5^{2 / 3}}{6}=45.63 \mathrm{~m}
\end{aligned}
$$

For momentum effects, $\mathrm{X}>\mathrm{XTEST}$ yielding

$$
\Delta h_{m}=3 * D H M O M=3 * 10.29=30.87 \mathrm{~m}
$$




$$
h(x)=20.0-0.00+45.63+30.87=96.5 \mathrm{~m}
$$

Using the same equation as above, the pollutant concentration was calculated to be $4.41 \mathrm{E}-07 \mathrm{~s} / \mathrm{m}^{3}$.

\subsection{Building Wake Effects}

The building wake effects will be verified using the input that was specified in Table 6 of the text.

For a downwind distance of $15 \mathrm{~m}$, the length that the recirculation cavity zone extends from the upwind edge of the building is determined using the following expression:

$\mathrm{L}_{\mathrm{c}} \approx 0.9 \mathrm{R}$

where

$R \approx\left(B_{\min }\right)^{0.667}\left(B_{\max }\right)^{0.333}$

where $B_{\min }$ is the smaller of $H$ and $W$ and $B_{\max }$ is the larger.

For the building

$\mathrm{R}_{\mathrm{u}} \approx(10)^{0.667(20)^{0.333}}$

$\mathrm{R}_{\mathrm{u}} \approx 12.6 \mathrm{~m}$
For the penthouse

$$
\begin{aligned}
& \mathrm{R}_{\mathrm{S}} \approx(5)^{0.667(10)^{0.333}} \\
& \mathrm{R}_{\mathrm{S}} \approx 6.3 \mathrm{~m}
\end{aligned}
$$

The total is $18.9 \mathrm{~m}$.

Next a series of tests must be performed as shown in Section 2.3 to determine the correct characteristic length to use for the remainder of the equations. The variable $X_{S}$ is equal to the length from the release point to the nearest edge of the building $(10 \mathrm{~m})$.

The conditions for this problem fell into the second set of criteria which are shown as follows.

(ii) $0.5\left(R_{\mathrm{u}}+\mathrm{R}_{\mathrm{S}}\right)<\mathrm{X}_{\mathrm{s}}<2\left(\mathrm{R}_{\mathrm{u}}+\mathrm{R}_{\mathrm{S}}\right)$.

$0.5(18.9)<10<2(18.9)$ is true therefore the recirculation cavity height $\mathrm{H}_{\mathrm{c}}$ and location $\mathrm{X}_{\mathrm{c}}$ on the upwind portion of the roof are calculated using $R=R_{u}+R_{s}$. The top of this cavity region is joined in a straight line with the top of the penthouse to form a high turbulence zone. The cavity height on the Penthouse roof and the downwind high turbulence zone boundary are then calculated using $R_{S}$ as a scale length. 
Since the position that has been chosen is on the upwind portion of the penthouse, $R_{\text {total }}$ will be used to determine the cavity height and length as follows:

$\mathrm{H}_{\mathrm{c}}=0.22 \mathrm{R}_{\text {total }}$

$\mathrm{H}_{\mathrm{c}}=0.22 * 18.86 \mathrm{~m}$

$\mathrm{H}_{\mathrm{c}}=4.15 \mathrm{~m}$

$$
\mathrm{X}_{\mathrm{c}}=0.5 \mathrm{R}_{\text {total }}
$$$$
\mathrm{X}_{\mathrm{c}}=0.5 * 18.86 \mathrm{~m}
$$$$
\mathrm{X}_{\mathrm{c}}=9.43 \mathrm{~m}
$$

The empirical formula for the length of the wake cavity is:

$\mathrm{X}_{\mathrm{r}}=\frac{\mathrm{A}^{*} \mathrm{~W}}{1+\mathrm{B}(\mathrm{W} / \mathrm{H})}$

Two separate combinations of values for A and B are used depending on whether the flow reattaches to the roof and sides of the building. Cases of reattachment occur when the roof cavity length $\left(\mathrm{L}_{c}\right)$ is less than the length of the building.

Test to see if $0.9 R_{\text {total }}<X_{c}$

$0.9 * 18.86<20$ is true.

For this case $\mathrm{A}=1.75$ and $\mathrm{B}=0.25$.

Using

$\mathrm{X}_{\mathrm{r}}=\frac{1.75 * 20 \mathrm{~m}}{1+0.25(20 / 10)}$

$\mathrm{X}_{\mathrm{r}}=23.33 \mathrm{~m}$

Since $\mathrm{X}_{\mathrm{S}}<0.5 \mathrm{R}$

$\mathrm{Z}=0.28 * \mathrm{R} *\left[\frac{\mathrm{X}}{\mathrm{R}}\right]^{0.333}$

$\mathrm{Z}=0.28 * 18.86 \mathrm{~m} *\left[\frac{5}{18.86}\right]^{0.333}$

$\mathrm{Z}=3.39 \mathrm{~m}$

$\mathrm{Z}_{\mathrm{tot}}=\mathrm{Z}+\mathrm{BHT}=3.39 \mathrm{~m}+10 \mathrm{~m}=13.39 \mathrm{~m}$

Now to determine the relative air concentration 


$$
\frac{\chi}{Q}=\frac{1}{2 \pi \sigma_{y} \sigma_{z} U_{s}}\left[e^{-\left(\frac{\left(z-h_{s}\right)^{2}}{2 \sigma_{z}^{2}}\right)}+e^{-\left(\frac{\left(z+h_{e}\right)^{2}}{2 \sigma_{z}^{2}}\right)}\right]
$$

For D stability $15 \mathrm{~m}$ downwind of release location

$$
\begin{aligned}
& \sigma_{\mathrm{y}}=\frac{\sigma_{\theta} \mathrm{x}}{1+0.031(\mathrm{x})^{0.46}} \quad \sigma_{\mathrm{z}}=0.06 \mathrm{x}(1+0.0015 \mathrm{x})^{-0.5} \\
& \sigma_{\mathrm{y}}=\frac{0.218 * 15 \mathrm{~m}}{1+0.031(15)^{0.46}} \quad \sigma_{\mathrm{z}}=0.06 * 15 \mathrm{~m}(1+0.0015 * 15)^{-0.5} \\
& \sigma_{\mathrm{y}}=2.954 \mathrm{~m} \quad \sigma_{\mathrm{z}}=0.890 \mathrm{~m} \\
& \frac{\chi}{\mathrm{Q}}=\frac{\mathrm{e}^{-0.5((13.4-20) / 0.89)^{2}+\mathrm{e}^{-0.5((13.4+20) / 0.89)^{2}}}}{2^{*} 3.14 * 2.954 \mathrm{~m}^{*} 0.890 \mathrm{~m}^{*} 6 \mathrm{~m} / \mathrm{s}}=1.13 \mathrm{E}-14 \mathrm{~s} / \mathrm{m}^{3}
\end{aligned}
$$

At the remaining distances the calculations are performed in a similar manner. Different equations may be used due to various tests and checks that are performed.

\subsection{Building Wake Effects and Plume Rise Verification}

A simple building was analyzed along with the effects of plume rise for this hand calculation. For input see Table 8 of text. The calculations for several of the parameters are not shown. The user can refer to the first section of this appendix for sample calculations of these parameters. Determination of all other parameters follows:

Downwind Distance of $30 \mathrm{~m}$.

Plume Rise

Since Fo $\leq 55$ and $X<X S T R$ the increase in plume height is equal to the following:

$$
\Delta h_{B}=1.6 \frac{F_{0}^{1 / 3} X^{2 / 3}}{U}=1.6 \frac{31.31^{1 / 3} 30^{2 / 3}}{4}=12.17 \mathrm{~m}
$$

For plume rise due to momentum,

$$
X T E S T=\frac{27.0 * D H M O M}{B 1}=\frac{27.0 * 15.4}{10.4}=39.98 \mathrm{~m}
$$


Since $\mathrm{X}$ is less than XTEST

$$
\Delta h_{m}=\left(B 1 * X * D H M O M^{2}\right)^{1 / 3}=\left(10.4 * 30 * 15.40^{2}\right)^{1 / 3}=4.2 .02 m
$$

For a ground level release with no downwash

$\Delta h=42.02+12.17=54.19 m$

Building Effects

Test to see if $0.9 R_{\text {total }}<X_{c}$

$0.9 * 12.6<30$ is true.

For this case $\mathrm{A}=1.75$ and $\mathrm{B}=0.25$.

Using

$\mathrm{X}_{\mathrm{r}}=\frac{1.75 * 20 \mathrm{~m}}{1+0.25(20 / 10)}=23.33 \mathrm{~m}$

For downwind distances less than the length of the building:

$Z=0.27 R-0.1 X$

$\mathrm{Z}=0.27 * 12.6-0.1 * 20=1.4 \mathrm{~m}$

$\mathrm{Z}_{\mathrm{tot}}=\mathrm{Z}+\mathrm{BHT}=10.0+1.4=11.4 \mathrm{~m}$

The relative air concentration is determined using the following equation:

$$
\frac{\chi}{Q}=\frac{1}{2 \pi \sigma_{y} \sigma_{z} U_{S}}\left[e^{-\left(\frac{\left(z-h_{e}\right)^{2}}{2 \sigma_{z}^{2}}\right)}+e^{-\left(\frac{\left(z+h_{e}\right)^{2}}{2 \sigma_{z}^{2}}\right)}\right]
$$

For C stability $30 \mathrm{~m}$ downwind of release location

$$
\begin{array}{ll}
\sigma_{\mathrm{y}}=\frac{\sigma_{\theta} \mathrm{x}}{1+0.031(\mathrm{x})^{0.46}} & \sigma_{\mathrm{z}}=0.08 \mathrm{x}(1+0.0002 \mathrm{x})^{-0.5} \\
\sigma_{\mathrm{y}}=\frac{0.305 * 30 \mathrm{~m}}{1+0.031(30)^{0.46}} & \sigma_{\mathrm{z}}=0.08^{*} 30 \mathrm{~m}(1+0.0002 * 30)^{-0.5} \\
\sigma_{\mathrm{y}}=7.98 \mathrm{~m} & \sigma_{\mathrm{z}}=2.39 \mathrm{~m}
\end{array}
$$




$$
\frac{\chi}{\mathrm{Q}}=\frac{\mathrm{e}^{-0.5((11.4-54.19) / 2.39)^{2}+\mathrm{e}^{-0.5((11.4+54.19) / 2.39)^{2}}}}{2^{*} 3.14^{*} 2.39 \mathrm{~m}^{*} 7.98 \mathrm{~m}^{*} 4 \mathrm{~m} / \mathrm{s}}=7.66 \mathrm{E}-73 \mathrm{~s} / \mathrm{m}^{3}
$$

Since both cesium and tritium have relatively long half lives the decay term is negligible and has been assumed to be one. Since $\mathrm{Ba}-137 \mathrm{~m}$ does not contribute to inhalation, the inhalation dose is calculated as follows for a distance of $30 \mathrm{~m}$ downwind:

$$
\begin{aligned}
D_{\text {inh }} & =\left[9.5 \mathrm{E} 4 \frac{\mathrm{mrem}}{\mathrm{Ci}}(3000 \mathrm{Ci})+3.2 \mathrm{E} 7 \frac{\mathrm{mrem}}{\mathrm{Ci}}(5000 \mathrm{Ci})\right] 7.66 \mathrm{E}-73 \frac{\mathrm{s}}{\mathrm{m}^{3}} 10500 \frac{\mathrm{m}^{3}}{\mathrm{yr}} 3.17 \mathrm{E}-8 \frac{\mathrm{yr}}{\mathrm{s}} \\
\mathrm{D}_{\mathrm{inh}} & =4.09 \mathrm{E}-65 \mathrm{mrem}
\end{aligned}
$$

The plume shine dose is calculated as follows with only Ba- $137 \mathrm{~m}$ contributing to the dose:

$$
\begin{aligned}
& \mathrm{D}_{\mathrm{PS}}=\left(\frac{\chi}{\mathrm{Q}}\right)\left(\mathrm{Q}_{\mathrm{n}}\right)\left(\mathrm{DFS}_{\mathrm{n}}\right) \mathrm{e}^{-\lambda_{\mathrm{n}} \mathrm{t}} \\
& \mathrm{D}_{\mathrm{PS}}=7.66 \mathrm{E}-73 \frac{\mathrm{s}}{\mathrm{m}^{3}} \times 5000 \mathrm{Ci} \times 97 \frac{\mathrm{mrem} / \mathrm{Ci}}{\mathrm{s} / \mathrm{m}^{3}} \mathrm{e}^{\left(-\frac{\ln 2 \times 30 \mathrm{~m}}{153 \mathrm{~s} \times 4 \mathrm{~m} / \mathrm{s}}\right)} \\
& \mathrm{D}_{\mathrm{PS}}=3.59 \mathrm{E}-67 \mathrm{mrem} \\
& \mathrm{D}_{\mathrm{T}}=4.09 \mathrm{E}-65 \mathrm{mrem}+3.59 \mathrm{E}-67 \mathrm{mrem} \\
& D_{\mathrm{T}}=4.12 \mathrm{E}-65 \mathrm{mrem}
\end{aligned}
$$

For a downwind distance of $45 \mathrm{~m}$ which is just beyond the building, the calculations are shown below.

For plume rise due to buoyancy with Fo $\leq 55$ and $X \leq X S T R$, the increase in height is

$$
\Delta \mathrm{h}_{\mathrm{B}}=1.6 \frac{\mathrm{F}_{\mathrm{o}}^{1 / 3} \mathrm{X}^{2 / 3}}{\mathrm{U}}=1.6 \frac{31.31^{1 / 3} 45^{2 / 3}}{4}=15.95 \mathrm{~m}
$$

Since $X>X T E S T$

$$
\begin{aligned}
& \Delta h_{m}=3 \times D H M O M=3 \times 15.4=46.2 \mathrm{~m} \\
& \Delta h=15.95 \mathrm{~m}+46.2 \mathrm{~m}=62.15 \mathrm{~m}
\end{aligned}
$$

Building Wake Effects

Since the point $\mathrm{X}$ is beyond the building, $\mathrm{Z}=0$.

Now to determine the relative air concentration 
$\frac{\chi}{Q}=\frac{1}{2 \pi \sigma_{y} \sigma_{z} U_{S}}\left[e^{-\left(\frac{\left(z-h_{e}\right)^{2}}{2 \sigma_{z}^{2}}\right)}+e^{-\left(\frac{\left(z+h_{c}\right)^{2}}{2 \sigma_{z}^{2}}\right)}\right]$

For C stability $45 \mathrm{~m}$ downwind of release location

$$
\begin{aligned}
& \sigma_{\mathrm{y}}=\frac{\sigma_{\theta} \mathrm{x}}{1+0.031(\mathrm{x})^{0.46}} \quad \sigma_{\mathrm{z}}=0.08 \mathrm{x}(1+0.0002 \mathrm{x})^{-0.5} \\
& \sigma_{\mathrm{y}}=\frac{0.305 * 45 \mathrm{~m}}{1+0.031(45)^{0.46}} \quad \sigma_{\mathrm{z}}=0.08^{*} 45 \mathrm{~m}(1+0.0002 * 45)^{-0.5} \\
& \begin{array}{ll}
\sigma_{\mathrm{y}}=11.66 \mathrm{~m} & \sigma_{\mathrm{z}}=3.58 \mathrm{~m}
\end{array}
\end{aligned}
$$

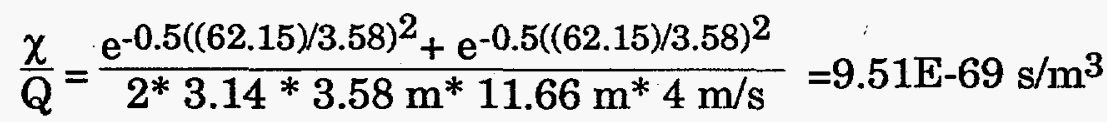

The inhalation dose is calculated as follows for a distance of $45 \mathrm{~m}$ downwind:

$$
\begin{aligned}
& \mathrm{D}_{\mathrm{inh}}=\left[9.5 \mathrm{E} 4 \frac{\mathrm{mrem}}{\mathrm{Ci}}(3000 \mathrm{Ci})+3.2 \mathrm{E} 7 \frac{\mathrm{mrem}}{\mathrm{Ci}}(5000 \mathrm{Ci})\right] 9.51 \mathrm{E}-69 \frac{\mathrm{s}}{\mathrm{m}^{3}} 10500 \frac{\mathrm{m}^{3}}{\mathrm{yr}} 3.17 \mathrm{E}-8 \frac{\mathrm{yr}}{\mathrm{s}} \\
& \mathrm{D}_{\text {inh }}=5.08 \mathrm{E}-61 \mathrm{mrem}
\end{aligned}
$$

The plume shine dose is calculated as follows with only Ba-137m contributing to the dose:

$$
\begin{aligned}
& \mathrm{D}_{\mathrm{PS}}=\left(\frac{\chi}{\mathrm{Q}}\right)\left(\mathrm{Q}_{\mathrm{n}}\right)\left(\mathrm{DFS}_{\mathrm{n}}\right) \mathrm{e}^{-\lambda_{\mathrm{n}}^{\mathrm{t}}} \\
& \mathrm{D}_{\mathrm{PS}}=9.51 \mathrm{E}-69 \frac{\mathrm{s}}{\mathrm{m}^{3}} \times 5000 \mathrm{Ci} \times 97 \frac{\mathrm{mrem} / \mathrm{Ci}}{\mathrm{s} / \mathrm{m}^{3}} \mathrm{e}^{\left(-\frac{\ln 2 \times 45 \mathrm{~m}}{153 \mathrm{~s} \times 4 \mathrm{~m} / \mathrm{s}}\right)} \\
& \mathrm{D}_{\mathrm{PS}}=4.38 \mathrm{E}-63 \mathrm{mrem} \\
& \mathrm{D}_{\mathrm{T}}=5.08 \mathrm{E}-61 \mathrm{mrem}+4.38 \mathrm{E}-63 \mathrm{mrem} \\
& \mathrm{D}_{\mathrm{T}}=5.12 \mathrm{E}-61 \mathrm{mrem}
\end{aligned}
$$

For a downwind distance of $100 \mathrm{~m}$.

For plume rise due to buoyancy and since Fo $\leq 55$ and $X<X S T R$ the increase in plume height is 


$$
\Delta \mathrm{h}_{\mathrm{B}}=1.6 \frac{\mathrm{F}_{0}{ }^{1 / 3} \mathrm{X}^{2 / 3}}{\mathrm{U}}=1.6 \frac{31.31^{1 / 3} 100^{2 / 3}}{4}=27.16 \mathrm{~m}
$$

Since X $>$ XTEST

$$
\Delta \mathrm{h}_{\mathrm{m}}=3 \times \mathrm{DHMOM}=3 \times 15.4=46.2 \mathrm{~m}
$$

$\Delta \mathrm{h}=27.16 \mathrm{~m}+46.2 \mathrm{~m}=73.36 \mathrm{~m}$

Building Wake Effects

Since the point $\mathrm{X}$ is beyond the building, $\mathrm{Z}=0$.

Now to determine the relative air concentration

$$
\frac{\chi}{Q}=\frac{1}{2 \pi \sigma_{y} \sigma_{z} U_{S}}\left[e^{-\left(\frac{\left(z-h_{e}\right)^{2}}{2 \sigma_{z}^{2}}\right)}+e^{-\left(\frac{\left(z+h_{c}\right)^{2}}{2 \sigma_{z}^{2}}\right)}\right]
$$

For C stability $100 \mathrm{~m}$ downwind of release location

$$
\begin{aligned}
& \sigma_{\mathrm{y}}=\frac{\sigma_{\theta} \mathrm{x}}{1+0.031(\mathrm{x})^{0.46}} \quad \sigma_{\mathrm{z}}=0.08 \mathrm{x}(1+0.0002 \mathrm{x})^{-0.5} \\
& \sigma_{\mathrm{y}}=\frac{0.305 * 100 \mathrm{~m}}{1+0.031(100)^{0.46}} \quad \sigma_{\mathrm{z}}=0.08^{*} 100 \mathrm{~m}(1+0.0002 * 100)^{-0.5} \\
& \sigma_{\mathrm{y}}=24.28 \mathrm{~m} \quad \sigma_{\mathrm{z}}=7.92 \mathrm{~m} \\
& \frac{\chi}{\mathrm{Q}}=\frac{\mathrm{e}^{-0.5((73.36) / 7.92)^{2}}+\mathrm{e}^{-0.5((73.36) / 7.92)^{2}}}{2^{*} 3.14 * 7.92 \mathrm{~m}^{*} 24.28 \mathrm{~m}^{*} 4 \mathrm{~m} / \mathrm{s}}=9.70 \mathrm{E}-23 \mathrm{~s} / \mathrm{m}^{3}
\end{aligned}
$$

The inhalation dose is calculated as follows for a distance of $100 \mathrm{~m}$ downwind:

$$
\begin{aligned}
\mathrm{D}_{\text {inh }} & =\left[9.5 \mathrm{E} 4 \frac{\mathrm{mrem}}{\mathrm{Ci}}(3000 \mathrm{Ci})+3.2 \mathrm{E} 7 \frac{\mathrm{mrem}}{\mathrm{Ci}}(5000 \mathrm{Ci})\right] 9.70 \mathrm{E}-23 \frac{\mathrm{s}}{\mathrm{m}^{3}} 10500 \frac{\mathrm{m}^{3}}{\mathrm{yr}} 3.17 \mathrm{E}-8 \frac{\mathrm{yr}}{\mathrm{s}} \\
\mathrm{D}_{\text {inh }} & =5.18 \mathrm{E}-15 \mathrm{mrem}
\end{aligned}
$$

The plume shine dose is calculated as follows with only Ba-137m contributing to the dose: 


$$
\begin{aligned}
& \mathrm{D}_{\mathrm{PS}}=\left(\frac{\chi}{\mathrm{Q}}\right)\left(\mathrm{Q}_{\mathrm{n}}\right)\left(\mathrm{DFS}_{\mathrm{n}}\right) \mathrm{e}^{-\lambda_{\mathrm{n}} \mathrm{t}} \\
& \mathrm{D}_{\mathrm{PS}}=9.70 \mathrm{E}-23 \frac{\mathrm{s}}{\mathrm{m}^{3}} \times 5000 \mathrm{Ci} \times 97 \frac{\mathrm{mrem} / \mathrm{Ci}}{\mathrm{s} / \mathrm{m}^{3}} \mathrm{e}^{\left(-\frac{\ln 2 \times 100 \mathrm{~m}}{153 \mathrm{~s} \times 4 \mathrm{~m} / \mathrm{s}}\right)} \\
& \mathrm{D}_{\mathrm{PS}}=4.20 \mathrm{E}-17 \mathrm{mrem} \\
& D_{\mathrm{T}}=5.18 \mathrm{E}-15 \mathrm{mrem}+4.20 \mathrm{E}-17 \mathrm{mrem} \\
& D_{\mathrm{T}}=5.22 \mathrm{E}-15 \mathrm{mrem}
\end{aligned}
$$

For a downwind distance of $500 \mathrm{~m}$.

For plume rise due to buoyancy, using the parameters shown in Figure A2 and since Fo $\leq 55$ and $\mathrm{X} \geq \mathrm{XSTR}$

$$
\Delta \mathrm{h}_{\mathrm{B}}=1.6 \frac{\mathrm{F}_{\mathrm{o}}{ }^{1 / 3} \mathrm{XSTR}^{2 / 3}}{\mathrm{U}}=1.6 \frac{31.31^{1 / 3} 421.69^{2 / 3}}{4}=70.90 \mathrm{~m}
$$

Since $\mathrm{X}>\mathrm{XTEST}$

$$
\begin{aligned}
& \Delta h_{m}=3 \times D H M O M=3 \times 15.4=46.2 \mathrm{~m} \\
& \Delta h=70.90 \mathrm{~m}+46.19 \mathrm{~m}=117.10 \mathrm{~m}
\end{aligned}
$$

Building Wake Effects

Since the point $\mathrm{X}$ is beyond the building, $\mathrm{Z}=0$.

Now to determine the relative air concentration

$$
\frac{\chi}{Q}=\frac{1}{2 \pi \sigma_{y} \sigma_{z} U_{S}}\left[e^{-\left(\frac{\left(z-h_{e}\right)^{2}}{2 \sigma_{z}^{2}}\right)}+e^{-\left(\frac{\left(z+h_{c}\right)^{2}}{2 \sigma_{z}^{2}}\right)}\right]
$$

For C stability $500 \mathrm{~m}$ downwind of release location

$$
\begin{array}{ll}
\sigma_{\mathrm{y}}=\frac{\sigma_{\theta} \mathrm{x}}{1+0.031(\mathrm{x})^{0.46}} & \sigma_{\mathrm{z}}=0.08 \mathrm{x}(1+0.0002 \mathrm{x})^{-0.5} \\
\sigma_{\mathrm{y}}=\frac{0.305 * 500 \mathrm{~m}}{1+0.031(500)^{0.46}} & \sigma_{\mathrm{z}}=0.08^{*} 500 \mathrm{~m}(1+0.0002 * 500)^{-0.5}
\end{array}
$$


$\sigma_{\mathrm{y}}=99.13 \mathrm{~m}$

$$
\sigma_{\mathrm{z}}=38.14 \mathrm{~m}
$$

$\frac{\chi}{Q}=\frac{\mathrm{e}^{-0.5((117.10) / 38.14)^{2}}+\mathrm{e}^{-0.5((117.10) / 38.14)^{2}}}{2^{*} 3.14 * 99.13 \mathrm{~m}^{*} 38.14 \mathrm{~m}^{*} 4 \mathrm{~m} / \mathrm{s}}=1.88 \mathrm{E}-07 \mathrm{~s} / \mathrm{m}^{3}$

The inhalation dose is calculated as follows for a distance of $500 \mathrm{~m}$ downwind:

$$
\begin{aligned}
& \mathrm{D}_{\text {inh }}=\left[9.5 \mathrm{E} 4 \frac{\mathrm{mrem}}{\mathrm{Ci}}(3000 \mathrm{Ci})+3.2 \mathrm{E} 7 \frac{\mathrm{mrem}}{\mathrm{Ci}}(5000 \mathrm{Ci})\right] 1.88 \mathrm{E}-7 \frac{\mathrm{s}}{\mathrm{m}^{3}} 10500 \frac{\mathrm{m}^{3}}{\mathrm{yr}} 3.17 \mathrm{E}-8 \frac{\mathrm{yr}}{\mathrm{s}} \\
& \mathrm{D}_{\text {inh }}=1.0 \mathrm{E}+1 \mathrm{mrem}
\end{aligned}
$$

The plume shine dose is calculated as follows with only Ba-137m contributing to the dose:

$$
\begin{aligned}
D_{P S} & =\left(\frac{\chi}{Q}\right)\left(Q_{n}\right)\left(D F S_{n}\right) e^{-\lambda_{n} t^{t}} \\
D_{P S} & =1.88 E-7 \frac{\mathrm{s}}{\mathrm{m}^{3}} \times 5000 \mathrm{Ci} \times 97 \frac{\mathrm{mrem} / \mathrm{Ci}}{\mathrm{s} / \mathrm{m}^{3}} e^{\left(-\frac{\ln 2 \times 500 \mathrm{~m}}{153 s \times 4 \mathrm{~m} / \mathrm{s}}\right)} \\
\mathrm{D}_{\mathrm{PS}} & =5.17 E-2 \mathrm{mrem} \\
\mathrm{D}_{\mathrm{T}} & =5.17 \mathrm{E}-2 \mathrm{mrem}+1.00 \mathrm{E}+1 \mathrm{mrem} \\
D_{\mathrm{T}} & =1.01 \mathrm{E}+1 \mathrm{mrem}
\end{aligned}
$$




\section{DISTRIBUTION (14)}

D. Moore-Shedrow, 773-A

J.B. Gladden, 773-42A

W. H. Carlton, 773-A

J. M. East, 730-2B

G.T. Jannik, 773-A

K. R. O'Kula, 730-2B

A. A. Simpkins, 773-A

SRTC Records(4), 773-52A

EDG Records(3), 773-A 